Florida International University FIU Digital Commons

7-2-2013

\title{
Wildfire Assessment Using FARSITE Fire Modeling: A Case Study in the Chihuahua Desert of Mexico
}

John Brakeall

Florida International University, jbrak001@fiu.edu

DOI: $10.25148 /$ etd.FI13080714

Follow this and additional works at: https://digitalcommons.fiu.edu/etd

Part of the Databases and Information Systems Commons, Forest Management Commons, Natural Resources Management and Policy Commons, Other Environmental Sciences Commons, and the Theory and Algorithms Commons

\section{Recommended Citation}

Brakeall, John, "Wildfire Assessment Using FARSITE Fire Modeling: A Case Study in the Chihuahua Desert of Mexico" (2013). FIU Electronic Theses and Dissertations. 923.

https://digitalcommons.fiu.edu/etd/923 


\section{FLORIDA INTERNATIONAL UNIVERSITY}

Miami, Florida

\section{WILDFIRE ASSESSMENT USING FARSITE FIRE MODELING: A CASE STUDY IN THE CHIHUAHUA DESERT OF MEXICO}

A thesis submitted in partial fulfillment of

the requirements for the degree of

MASTER OF SCIENCE

in

ENVIRONMENTAL STUDIES

by

John Brakeall 
To: Dean Kenneth G. Furton

College of Arts and Sciences

This thesis, written by John Brakeall, and entitled Wildfire Assessment using FARSITE Fire Modeling: A Case Study in the Chihuahua Desert of Mexico, having been approved in respect to style and intellectual content, is referred to you for judgment.

We have read this thesis and recommend that it be approved.

Assefa Melesse

$\begin{array}{r}\text { Keqi Zhang } \\ \hline \text { Jeffrey Onsted, Major Professor }\end{array}$

Date of Defense: July 2, 2013

The thesis of John Brakeall is approved.

$\begin{array}{r}\hline \begin{array}{c}\text { Dean Kenneth G. Furton } \\ \text { College of Arts and Sciences }\end{array} \\ \hline \begin{array}{r}\text { Dean Lakshmi N. Reddi } \\ \text { University Graduate School }\end{array}\end{array}$

Florida International University, 2013 


\section{DEDICATION}

I dedicate this thesis to my family, beginning with my mother, and my father, to whom I am eternally indebted for the love, support, and encouragement that they have been providing throughout my lifetime. I would like to dedicate this thesis to my fiancé. Without her patience, understanding, support, and most of all love, the completion of this work would not have been possible. 


\section{ACKNOWLEDGMENTS}

I wish to thank the United States Peace Corps and the Comisión Nacional de Áreas Naturales Protegidas (CONANP) in Mexico for providing me with the opportunity and support to make this study possible. I would also like to thank the members of my committee, Dr. Assefa Melesse and Dr. Keqi Zhang, for their support and patience throughout my experience in the Master's International program. Their direction any support while I was out of the country was very much appreciated. I acknowledge the Department of Earth and Environment for providing me with a graduate assistantship and teaching assistantship during my time at FIU. Finally, I would like to thank my major professor, Dr. Jeffrey Onsted. Dr. Jeffrey Onsted's support and direction was crucial for me in choosing my topic and executing my work. 


\title{
ABSTRACT OF THE THESIS \\ WILDFIRE ASSESSMENT USING FARSITE FIRE MODELING: A CASE STUDY IN THE CHIHUAHUA DESERT OF MEXICO
}

\author{
by \\ John Brakeall \\ Florida International University, 2013 \\ Miami, Florida \\ Professor Jeffrey Onsted, Major Professor
}

The Chihuahua desert is one of the most biologically diverse ecosystems in the world, but suffers serious degradation because of changes in fire regimes resulting in large catastrophic fires. My study was conducted in the Sierra La Mojonera (SLM) natural protected area in Mexico. The purpose of this study was to implement the use of FARSITE fire modeling as a fire management tool to develop an integrated fire management plan at SLM.

Firebreaks proved to detain $100 \%$ of wildfire outbreaks. The rosetophilous scrub experienced the fastest rate of fire spread and lowland creosote bush scrub experienced the slowest rate of fire spread. March experienced the fastest rate of fire spread, while September experienced the slowest rate of fire spread. The results of my study provide a tool for wildfire management through the use geospatial technologies and, in particular, FARSITE fire modeling in SLM and Mexico. 


\section{TABLE OF CONTENTS}

CHAPTER

PAGE

CHAPTER 1 OVERVIEW AND INTRODUCTION.......................................

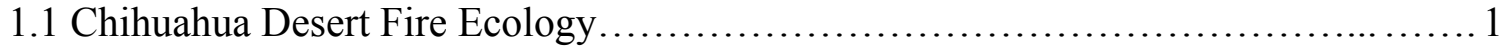

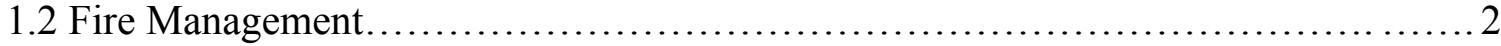

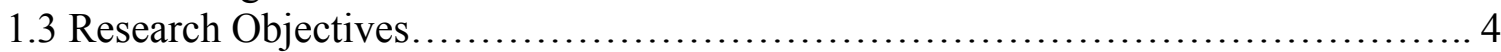

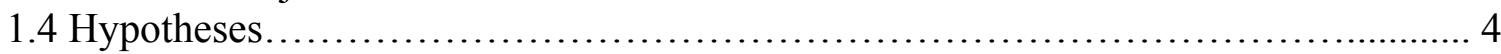

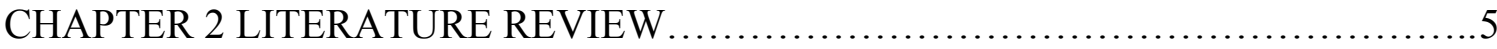

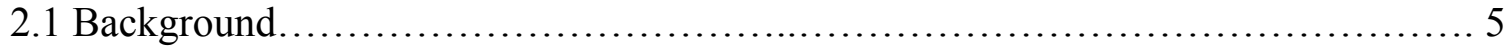

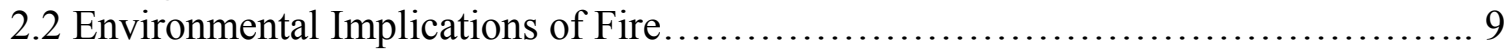

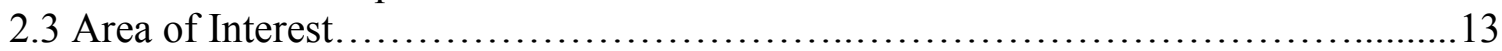

2.4 Current Environmental Management.............................................. 15

2.5 Proposed Environmental Management......................................... 17

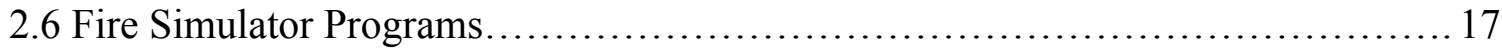

2.7 FARSITE Fire Simulator......................................................... 21

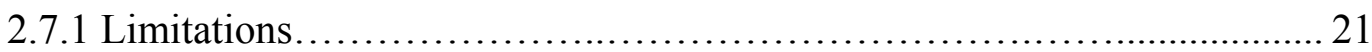

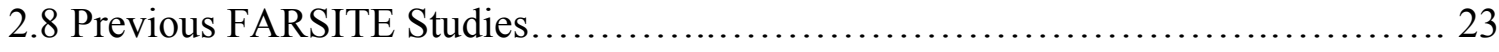

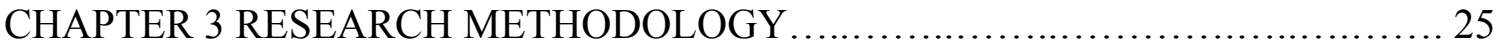

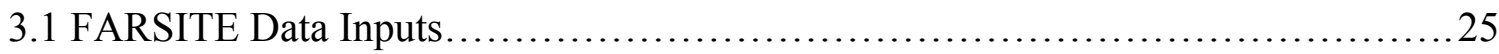

3.2 Methodology of Previous Studies ................................................ 31

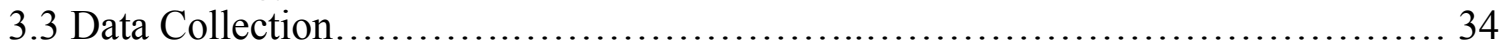

3.3.1 Topographic Data.................................................. 34

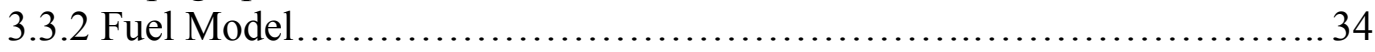

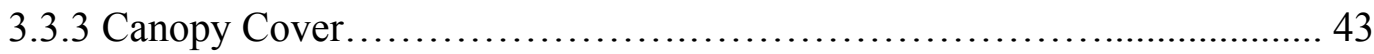

3.3.4 Meteorological Data................................................. 43

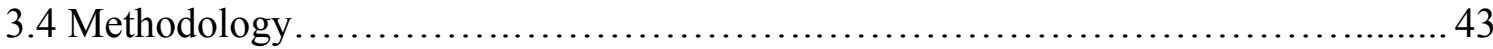

3.4.1 Objective Methodology.................................................. 43

3.4.2 Objective 2 Methodology ........................................... 44

3.4.3 Objective 3 Methodology ...........................................45

3.4.4 Model Accuracy Methodology........................................ 45

3.5 Limitation and Potential Errors................................................... 46

CHAPTER 4 RESULTS.................................................................. 48

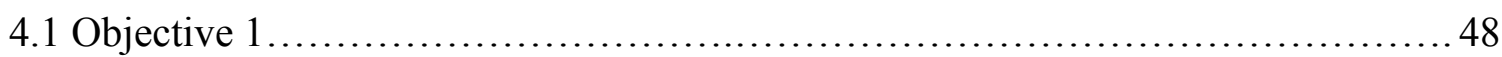

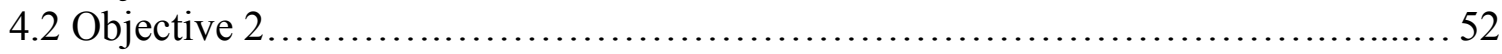

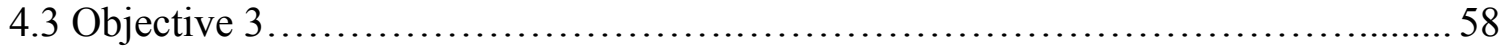

4.4 Model Accuracy Evaluation...............................................64

CHAPTER 5 DISCUSSION AND CONCLUSIONS....................................... 71

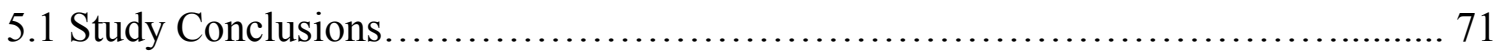

5.2 Limitations of Results..................................................... 74 
5.3 Closing Remarks.................................................... 76

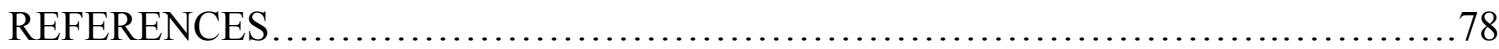

APPENDIX .............................................................. 90 


\section{LIST OF TABLES}

TABLE

PAGE

Table 1: Summary of projects and financial allocations for wildfire projects in the SLM

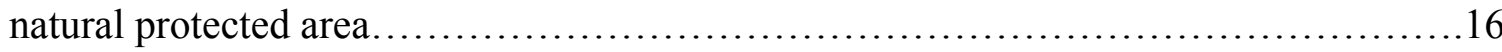

Table 2: Summary of BehavePLUS, FlamMap, and FSPro fire modeling programs that use the CA surface fire growth model. FARSITE included for comparison.

Table 3: Required weather data format for FARSITE

Table 4: Inverse pattern of temperature and relative humidity showing cosine interpolation over a 5 -day period............................................. 28

Table 5: Required wind data format for FARSITE............................... 28

Table 6: Extended set of NFFL fire behavior fuel models......................... 29

Table 7: Results of Gaussian Maximum Likelihood supervised classification.......... 41

Table 8: Summary of Chi Square Analysis for testing firebreak efficacy. All 3 firebreaks effectively stopped fire in $\% 100$ of simulations............................... 49

Table 9: Results of Chi Square Analysis for all three firebreaks.................... 50

Table 10: Descriptive statistics generated from one-way ANOVA analysis............. 52

Table 11: Multivariate test that conclude significant difference between mean size of fire

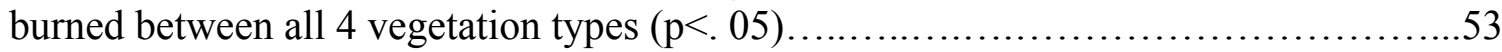

Table 12: Tests of Within-Subjects Effects showing degrees of freedom $(3,141)$ and $F$ test $(\mathrm{F}=71.686)$ showing significant difference between vegetation types $(\mathrm{p}<.05) \ldots \ldots 53$

Table 13: Pairwise comparisons test based on estimated marginal means. ${ }^{*}$ signifies the mean difference is significant at the .05 level. ${ }^{b}$ is adjustment for multiple comparisons:

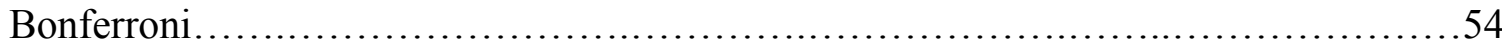

Table 14: Descriptive statistics generated from one-way ANOVA test.................. 59

Table 15: Multivariate test that conclude significant difference between mean size of

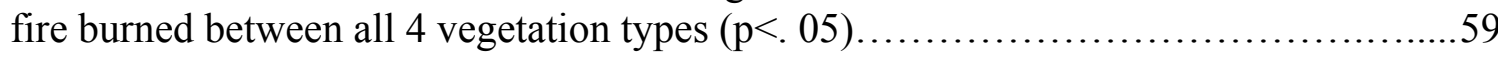

Table 16: Tests of Within-Subjects Effects showing $(\mathrm{df}=11,253 ; \mathrm{F}=11.084)$ significant

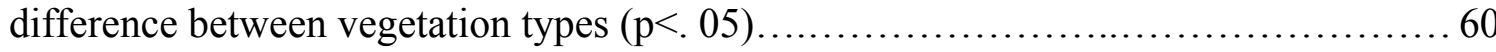


Table 17: Pairwise comparisons test based on estimated marginal means. ${ }^{*}$ signifies the mean difference is significant at the .05 level. $^{b}$ is adjustment for multiple comparisons:

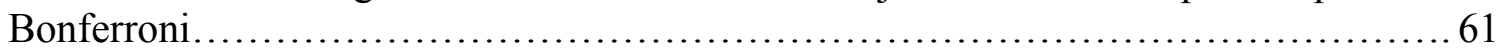

Table 18: Iterations with various adjustment factors for the March 23, 2008 fire........67

Table 19: Iterations with various adjustment factors for the April 12/13, 2011 fire....... 70 


\section{LIST OF FIGURES}

FIGURE

PAGE

Figure 1: Total area of desert-land affected by fire annually (1999-2011) in the republic of Mexico.....

Figure 2: Map of the Natural Protected Area, SLM.................................14

Figure 3: The five required and three optional spatial data files used in FARSITE.....26

Figure 4: Equation for calculating NDVI.................................... 33

Figure 5: Model created in ERDAS Imagine 9.1 to convert DN values to spectral radiance

Figure 6: Model created in ERDAS Imagine 9.1 to correct for exoatmospheric reflectance.

Figure 7: Non-Lambertian model included in ERDAS Imagine 9.1 to correct for

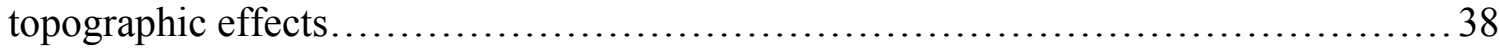

Figure 8: Map demonstrating localities of all three (3) firebreaks in SLM............... 49

Figure 9: Map demonstrating the successful cessation of a fire simulation by El Gallo

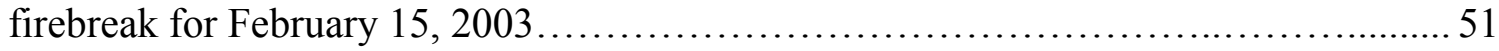

Figure 10: Map demonstrating the successful cessation of a fire simulation by

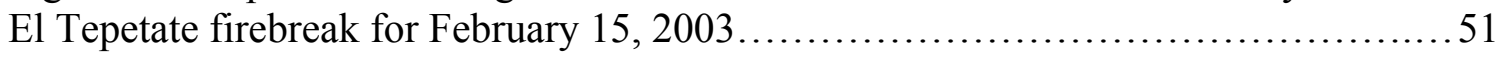

Figure 11: Map demonstrating the successful cessation of a fire simulation by

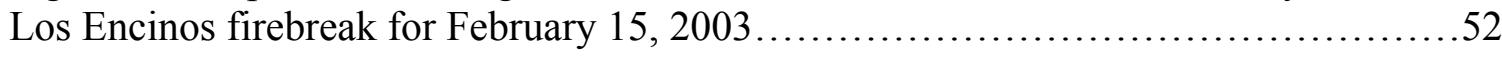

Figure 12: Map showing fire perimeter (0.12 ha.) in fuel model SH1 at site $2 \ldots \ldots \ldots . . .55$

Figure 13: Map showing fire perimeter (0.43 ha.) in fuel model SH2 at site $2 \ldots \ldots \ldots . . .55$

Figure 14: Map showing fire perimeter (160.33 ha.) in fuel model SH5 at site $2 \ldots . \ldots . .56$

Figure 15: Map showing fire perimeter (145.102 ha.) in fuel model SH7 at site 2......... 57

Figure 16: Overall fire vulnerability assessment in SLM based on vegetation type......58

Figure 17: Actual extent of fire that occurred on March 23, 2008. Fire burned 99.5 hectares. 64 
Figure 18: Simulation of fire that occurred on March 23, 2008. Simulated fire burned

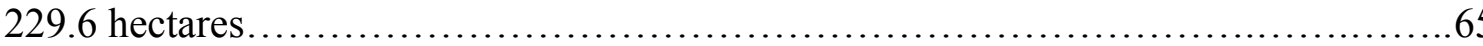

Figure 19: Spread rate adjustment file created for March 23, 2008 fire simulation.......66 66

Figure 20: Simulation of fire that occurred on March 23, 2008 with 0.43 adjustment value. Simulated fire burned 52.2 hectares.

Figure 21: Actual extent of fire that occurred on April 12/13, 2011. Fire burned 286.4

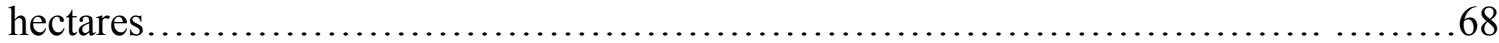

Figure 22: Simulation of fire that occurred on April 12/13, 2011. Simulated fire burned 592.6 hectares

Figure 23: Simulation of fire that occurred on April 12/13, 2011 with 0.43 adjustment factor. Simulated fire burned 52.2 hectares....................................... 70 


\section{ABBREVIATIONS AND ACRONYMS}

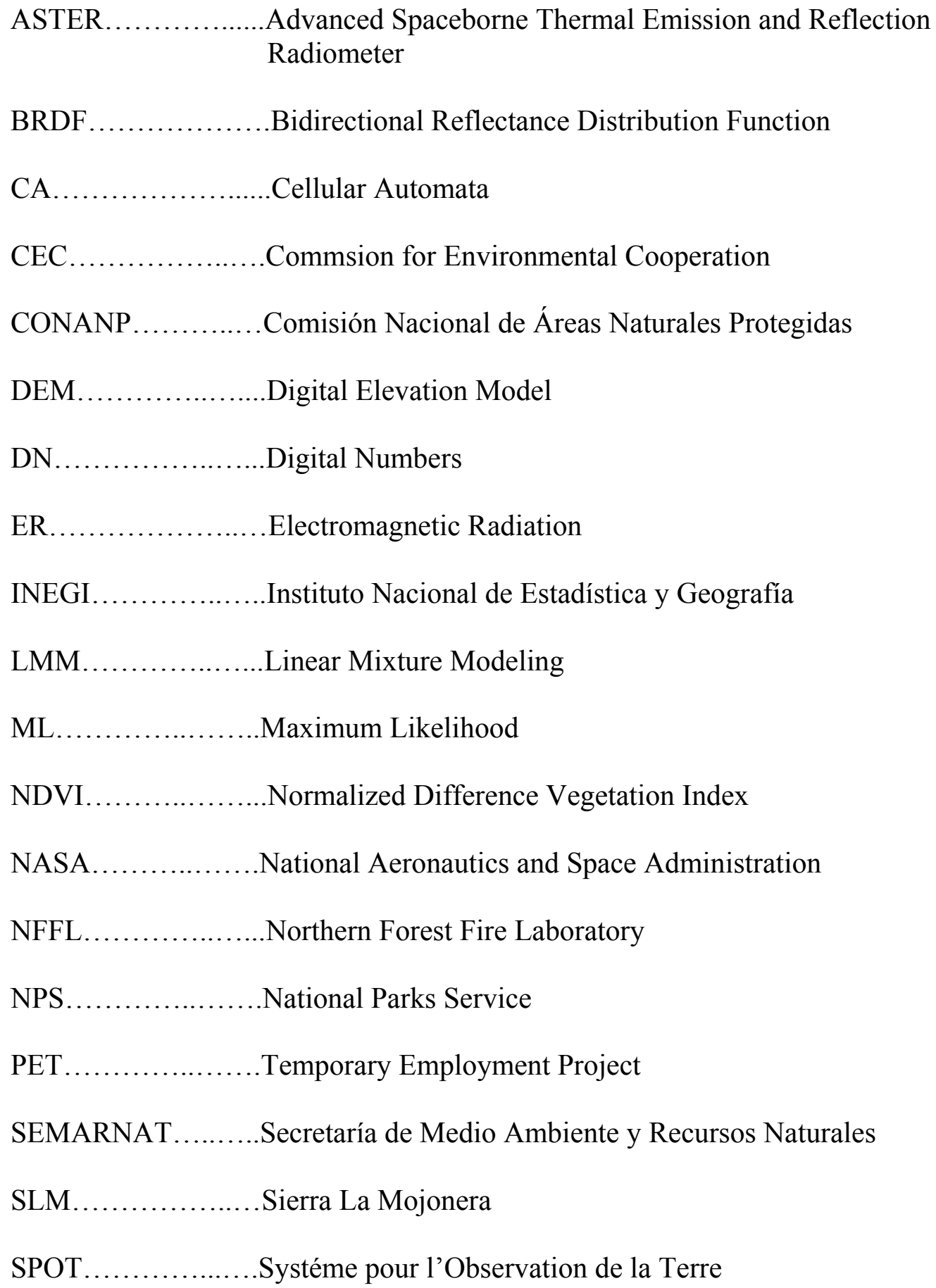




\section{CHAPTER 1}

\section{OVERVIEW AND INTRODUCTION}

\subsection{Chihuahua Desert Fire Ecology}

The Chihuahua desert is the largest desert in North America, extending throughout the southwestern United States and northern Mexico (World Wildlife Fund, 2011). The Chihuahua desert is the most biologically diverse desert within the western hemisphere and among the most biologically diverse ecosystems in the world (Pronatura et al., 2004). Its very high species diversity and endemism is a consequence of unique geology and topography that is unlike any other desert (Chihuahuan Desert Education Coalition, 2011). The desert is very important because of its biological wealth, but also represents an important international conservation effort between the United States and Mexico (Pronatura et al., 2004). Conservation groups are developing international alliances between Mexico and the United States to conserve this vast and rich ecosystem. These conservation efforts are very important because estimates from the Commission for Environmental Cooperation (CEC) suggest that between $50-70 \%$ of the land in the Chihuahua desert are in some state of degradation (2011). One of the most significant causes of this land degradation is a result of the changes in fire regimes.

These changes in fire regimes began during the $16^{\text {th }}$ century with the conquest of Mexico by Spain. The European ideology of fire suppression became the way of the land

until research came out in the $20^{\text {th }}$ century suggesting the reintroduction of fire (Loucks, 1970). By this time fuels/dead organic material had built up in the natural environment and many ecosystems had reached a climax state (Pyne, 1992; Pyne 2001). When fire 
was reintroduced into the Chihuahua desert the environmental effects were highly undesirable.

The Chihuahua desert is not adapted to the intensity of current $21^{\text {st }}$ century fires (Ansley, 2011). As a result of the accumulation of fuels for several centuries, fires are now burning hotter, longer, and more frequently than historical fire regimes (Ibid). Moreover, plant communities in the Chihuahua desert have reached a climax state and age diversity has largely disappeared throughout the ecosystem (Ibid). When fires do occur, mortality is high and the ecosystem suffers from low age diversity. The regeneration process is slow because of low fertility levels in adult plants. These open niches have allowed for the introduction of some highly invasive grasses including the African love-grasses (Eragrostis sp.). Additionally, these high intensity fires have exacerbated effects on soil quality and erosion (Ansley, 2011; Esque et al., 2010; Fleischner, 1994).

The key to ecosystem health in the Chihuahua desert is an integrated fire management plan that mitigates hazardous high intensity fires while slowly reintroducing fire into the ecosystem. Two common fire management techniques include firebreaks to stop large devastating fires and prescribed burns to slowly restore fire to its historic regime.

\subsection{Fire Management}

A firebreak is a barrier or a removal of fuel designed to stop the spread of fire (Green, 1977). The use of firebreaks as a fire management tool has been around since 1866 (Ibid). Anthropogenic firebreaks are commonly used because fire managers can strategically choose the most beneficial location for the firebreak. Firebreaks are now 
used on all continents (except Antarctica) and a variety of ecosystems (Omi, 1996). However, there are no standardized rules in the location, size, or construction of firebreaks (Agee et al. 2000). With firebreaks there are many variables to consider such as terrain, weather, fuels, and historic fire regimes (Agee et al., 2000; Omi, 1996). Consequently, firebreaks can be a great fire management tool, but require proper planning to be effective.

Another commonly used fire management tool is the use of prescribed burns. Prescribed burns are planned fires designed to simulate historic fire regimes and reduce the severity and damage of natural wildfires (Richards \& Hay, 2007). The use of a prescribed fire can be a very beneficial tool when dealing with post fire plant communities such as those in the Chihuahua desert (Ansley, 2011). These prescribed fires can be low intensity and restore vitality to these once fire dependent ecosystems (Ibid).

The main objective of my study is to implement FARSITE fire modeling to assist with fire management at the Sierra La Mojonera (SLM) natural protected area in San Luis Potosí, Mexico. The software technology will be used to determine if current firebreaks are effective in detaining fire. The FARSITE model will also be used to determine when the safest month is for implementing prescribed burns as a means of slowly reintroducing fire into the SLM and which month is the most vulnerable to catastrophically large fires. Lastly, FARSITE modeling will be used to determine which vegetation type/subecosystem is the most vulnerable to fire.

My study will establish the use of GIS technologies and FARSITE modeling for wildfire management practices within the SLM natural protected area. FARSITE fire modeling software has been used extensively throughout the United States portions of the 
Chihuahua desert, but has rarely been applied throughout Mexico. The intention of this study is to advance the use of FARSITE in Mexico and the Mexican Chihuahua desert. The expectation is that FARSITE modeling will become the authority for fire management decisions in SLM and provide innovation for further use of FARSITE within Mexico's Comisión Nacional de Áreas Naturales Protegidas (CONANP).

\subsection{Research Objectives}

I propose the use of FARSITE wildfire modeling in the SLM natural protected area to:

- Determine if current firebreaks are effective.

- Determine which month is the safest to implement prescribed burns and which month is most susceptible to catastrophic fire based on rates of fire spread.

- Determine which vegetation types/sub-ecosystems within the protected area will experience the fastest rate of fire spread.

\subsection{Hypotheses}

Hypothesis 1: Current firebreaks are sufficient to contain current fire intensity. Hypothesis 2: Vegetation types with greater biomass will experience faster fire spread.

Hypothesis 3: Prescribed burns should be conducted in the months of late fall such as October. The month of April will experience the fastest rate of fire spread. 


\section{CHAPTER 2}

\section{LITERATURE REVIEW}

\subsection{Background}

Fire has always been an integral part of ecology throughout an array of ecosystems. However, there has been a significant increase in the number of catastrophic wildfires occurring globally (Food and Agricultural Organization of the United Nations, 2001). In fact, many of these catastrophic fires have been classified as mega-fires, which are characterized by their inability to be controlled regardless of control efforts or resources used (Williams, 2004). Mega-fires now account for $90 \%$ of land burned and $80 \%$ of suppression costs in the United States (Williams, 2004). As a result, wildfire suppression costs have grown exponentially (Ingalsbee, 2010). The United States Forest Service’s spending on wildfire suppression rose from \$300 million in 1997 to $\$ 1.5$ billion in 2006 (Cohan \& Burnett, 2008). More importantly, since 2004 greater than 3,000 people have died each year in the United States alone from wildfires (United States Fire Administration, 2011). These catastrophic wildfires pose a serious threat to economies, ecology, and human life globally and not just in the United States. A recent catastrophic mega-fire in southeast Australia burned 2,200 square kilometers in late 2009 killing over 200 people and destroying 750 homes (Associated Press, 2009). There are several culprits contributing to the increased severity of wildfires with climate change and the accumulation of biomass within ecosystems at the forefront (Liu et al., 2010). These culprits have negatively affected fire regimes in many ecosystems, including drylands.

Drylands, which include semi-arid deserts, cover over $40 \%$ of the earth's land surface. These dry lands are home to over 2 billion people, largely within the developing 
word (MEA, 2005). Deserts are often viewed as lifeless wastelands, but in reality contain some of the most highly specialized species (National Parks Service, 2011). Deserts contain a wide variety of biodiversity as well as an array of economically viable resources. However, it is estimated that $70 \%$ of these drylands are affected by land degradation, according to the United Nations Convention to Combat Desertification (1992). The leading causes of degradation include climate change, overgrazing, changes in fire regimes, and unsustainable land cultivation practices (Nicholson, 1998). Many of the aforementioned causes of degradation work in tandem to degrade desert ecosystems. This is no exception for the Chihuahua desert, which is estimated to have between 50-70 percent of its land in a state of degradation (CEC, 2011).

The Chihuahua desert is the largest desert in North America extending throughout the southwestern United States and northern Mexico (WWF, 2011). The Chihuahua desert contains very high species diversity and endemism as a consequence of its unique basin and range topography and high elevation (Chihuahuan Desert Education Coalition, 2011). The average elevation throughout the Chihuahua desert is 4,500 feet $(1,372 \mathrm{~m})$ above sea level. As a result of these unique circumstances, the Chihuahua desert contains over 3,500 species of plants, 176 species of mammals, 156 species of reptiles, 46 species of amphibians and over 500 species of birds (Findley \& Caire, 1974; Phillips, 1974; NPS, 2011). There are greater than 1,000 endemic plant taxa in the Chihuahua desert, many of which are cacti (Pronatura et al., 2004). In particular, the Chihuahua desert contains 345 cacti species of the 1,500 species known worldwide making it the quintessential locus of cacti diversity (Hoyt, 2002; NPS, 2011). In short, the Chihuahua desert is one of the most 
biologically diverse deserts in the world as well as one of the most endangered (Hoyt, 2002).

Many of the problems that threaten the Chihuahua desert today began at the beginning of the $16^{\text {th }}$ century. A large anthropogenic revolution occurred in the Chihuahua desert at this time with the arrival of Europeans to the New World (West, 2000). The Spanish conquest of Mexico during the early $16^{\text {th }}$ century induced a revolution in agricultural practices and land management. Changes included the introduction of domesticated grazing animals like sheep, goats, and cows as well as the exclusion of fire from natural landscapes (Rodríguez-Trejo, 2011; Pyne, 1992; Pyne 2001). Excessive grazing of domesticated sheep, goats, and cows as well a change in fire regimes became the way of the land for the next 400 years (West, 2000).

The centuries of livestock overgrazing coupled with altered fire regimes has allowed woody shrubs to encroach on perennial grasslands. Native woody shrubs like mesquite (Prosopis glandulosa), creosote bush (Larrea tridentata) and others have flourished in many areas that were historically grasslands (Havstad, 2010; Peters, 2006; Sauer, 1950; Humphrey, 1963; McPherson, 1995). Meanwhile, fire suppression, associated with increasing population, land development, and misinformation about fire lead to an accumulation of 'fuel' within the ecosystem. Moreover, many of the species that were introduced from European colonization became naturalized or, in some cases, invasive. Species of fire tolerant invasive grasses like African love-grass (Eragrostis sp.) have proliferated, replacing native grasses (Abella, 2009). These changes in the Chihuahua desert of northern Mexico have greatly impacted the dynamics of this ecosystem. 
A more recent phenomenon that has altered fire regimes in the Chihuahua desert includes climate change. Climate change is exacerbating disturbance regimes and thereby accelerating vegetation change (Fulé, 2008). The rapid alterations in ecology as an outcome of climate change in tandem with non-native biotic factors may create a condition never before seen in evolutionary history (Ibid). The effects from climate change are not uniform throughout the world. A study conducted by Seager et al. (2007) ran climatic models to predict climatic changes for various regions and ecosystems. The findings revealed that the average of 19 climate models consistently predict increased drying within the Chihuahua desert of the southwestern United States and northern Mexico (Seager et al., 2007). These findings come as no surprise considering the severity of drought-like weather the Mexican Chihuahua desert has recently endured.

Increased understanding of fire ecology throughout the $20^{\text {th }}$ century has allowed land managers to reintroduce wildfire into natural ecosystems at perceived preColumbian disturbance regimes (Loucks, 1970). The hope is to restore ecosystems to their historical fire regimes as many studies suggest that these ecosystems are fire dependent (Wooton, 1916; Humphrey, 1958; McPherson, 1995). However, the intensity and frequency of fires and their subsequent effects are not the same as the pre-Columbian era. Historic fire patterns in the Chihuahua desert are characteristic of being low intensity and having a small spatial extent (Havstad \& James, 2010). These characteristics are no longer the case in the Chihuahua desert. Due to the aforementioned changes in this environment, the ecological and economical results of fire can now be devastating (Pyne, 1992). 
In 2011, Mexico experienced their worst drought and fire season within the past 70 years (Rhoda \& Burton, 2010). The lack of rain and frost throughout the 2010-2011 winter left plants dry and vulnerable to fire. The results were several mega-fires through the spring season in northern Mexico. One particular fire in April burned 250 square kilometers and required emergency response from the United States and Canada (Rhoda \& Burton, 2010). The Mexican government spent over $\$ 30$ million USD in combat efforts (Cárdenas, 2011), which accounted for nearly half of their annual budget of $\$ 65$ million allocated to combat wildfire (Rhoda \& Burton, 2010). The findings from Seager et al. (2007) as well as others (Gebow \& Halverson, 2005) suggest that the recent droughts within this region may become the new norm. If this is the case, the Chihuahua desert will face more catastrophic fire seasons, like 2011.

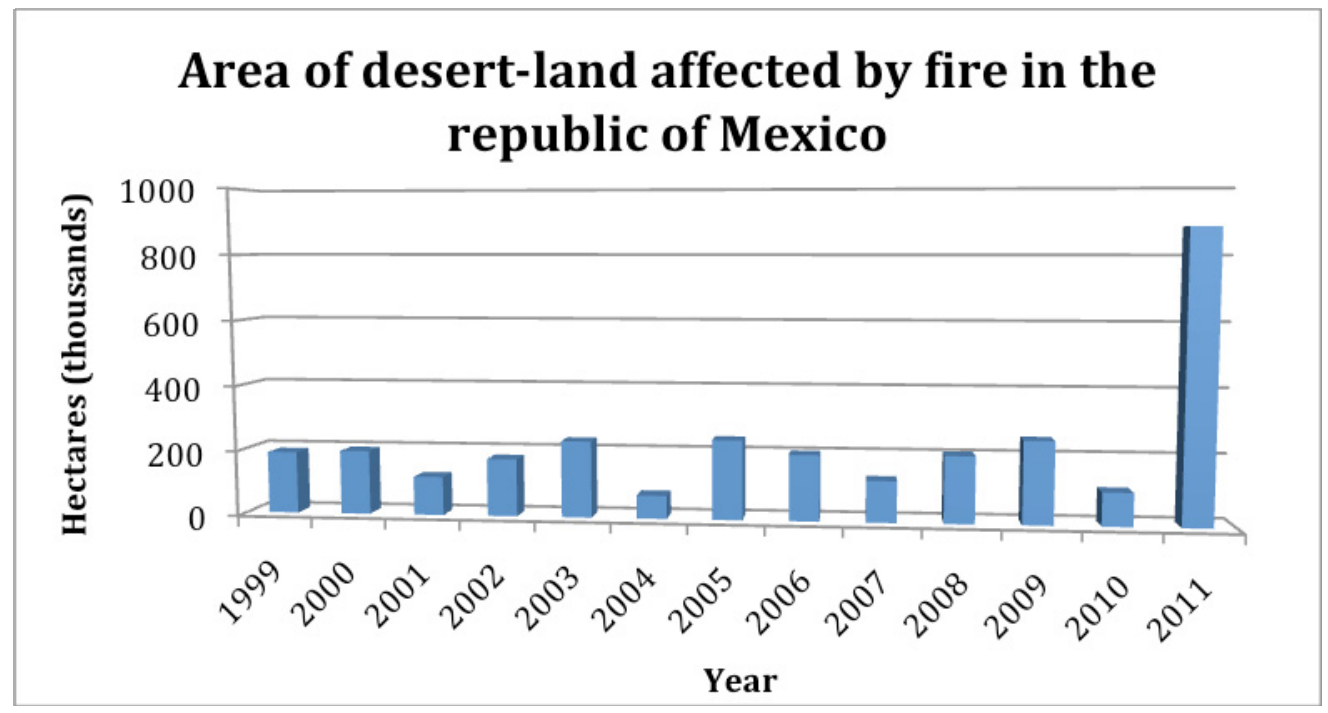

Figure 1: Total area of desert-land affected by fire annually (1999-2011) in the republic of Mexico (Comisión Nacional Forestal, 2011).

\subsection{Environmental Implications of Fire}

The accumulation of biomass from fire suppression and the naturalization of invasive plants in the environment have fires burning hotter, longer, and more frequently 
than pre-Columbian fires. The vegetation in the Chihuahua desert is not adapted nor is it dependent upon the intensity of current fires (Ansley, 2011). The ecosystem is historically adapted to fire, but since fire was removed for hundreds of years fuels have built up and age diversity within the ecosystem has disappeared (Ansley, 2011). There is now little to no age diversity within the Chihuahua desert because all individuals within each species have grown to maturity. When fires do occur, damage is vast and the ecosystem starts entirely from youth. Subsequently, ecosystem diversity plummets. Under normal fire regimes, a large number of species may die within the area affected by fire (fire scar), but will become re-colonized by neighboring cohorts from adjacent nonburned patches (Pianka, 1992). The natural cycle becomes disturbed when fuel builds up and fires spread further making re-colonization more difficult. Moreover, this cycle is retarded when fire is reintroduced into a climax ecosystem like the Chihuahua desert (Ansley, 2011). Fertility levels of older specimen are lower leaving post-fire recovery to be much slower in the face of catastrophic fire (Ibid). Without age diversity in an ecosystem ecological health suffers. The slow recovery of native species also provides an open niche for their displacement by invasive species.

There are also critical effects on soil stability that are caused from larger and more intense fires (Ansley, 2011). After fire, there is little to no vegetation left to hold the soil from wind and water erosion. The result is typical in all ecosystems after fire, but it is highly detrimental to desert ecosystems as erosion is already viewed as a large threat to desert ecosystems (Fleischner, 1994). Furthermore, many studies have found that fireinduced soils have decreased hydraulic conductivity (K) after burns (Doerr et al., 2000; 
Ravi et al., 2006; Ravi et al., 2009). The phenomenon causes the soil to repel water and lead to increased soil erosion.

Other important adverse soil effects of fire in the Chihuahua desert include the loss of soil organic matter and loss of soil seed banks in the shallow soil layers (Abella et al., 2009). The result is very important as seed banks represent the future potential for plant populations (Esque et al., 2010). Todd Esque et al. (2010) found seed bank mortality rates of $55-80 \%$ for species found in the Chihuahua desert. Other research suggests that seed damage is dependent upon the duration and intensity of fire temperature (Esque et al., 2010; McKell et al., 1962). Increased intensity of fire has negatively affected seed bank fecundity in the Chihuahua desert.

One of the most valuable environmental resources within the Chihuahua desert is the biological diversity in cacti, which are notoriously poorly adapted to fire (Oldfield, 1997). With increased temperature and intensity of fires, endangered cacti populations will likely decrease. Previous studies have found high mortality rates in many species of cacti after fire (Worthington \& Corral, 1987). A study by Thomas found cacti mortality to be significantly higher in years with dense annual vegetation from heavy rains (1991). These findings may suggest that ecosystems with uncharacteristically high fuel will have greater cacti mortality.

Other studies have found high rates of cacti mortality (over 50\%) in the presence of fire (Worthing \& Corral, 1987; Humphrey, 1963; Trabaud, 1987). The species Opuntia imbricata, which has been placed on the Norma Oficial Mexicana-059 list of endangered species by the Mexican government, was found to have a mortality rate of $70 \%$ in the presence of fire, according to a study by Worthington and Corral (1987). Also, cacti do 
not store seeds in a seed bank (Humphrey, 1974), which proves cacti to be even more vulnerable to fire. These threats are very important to consider in land management decisions as the country of Mexico has the greatest biological diversity and endemism of cacti in the world (Hernandez \& Godinez, 1994). Similarly, Mexico has the greatest number of endangered species of cacti in the world (Ibid).

The introduction of invasive species is another ecological threat, which is indirect, yet imminent. Livestock overgrazing has proven to be one of the most pervasive land use changes through the semi-arid deserts of North America (Brooks \& Pyke, 2002). The effect of overgrazing has been very influential on fire. The centuries of excessive grazing of forage plants has decimated populations of native grasses. The change has lead to the displacement of invasive species into the open niches of native grasses (Elton, 1958; Simberloff, 1995). These invasive grasses are able to utilize soil resources at faster rates than natives (Eissenstat \& Caldwell, 1988; Melgoza \& Nowak, 1991). Subsequently, invasive annual grasses that have become naturalized in this region now outcompete native annual grasses of the Chihuahua desert (Inouye, 1980; Pake, 1993; Brooks, 2000).

One genus of invasive grasses that has permeated the Chihuahua desert includes the genus of African love-grasses (Eragrostis sp.). These grasses proliferate with frequent fire and recover more quickly than native species after fire (Pase, 1971; Martin, 1983). Moreover, African love-grasses are believed to increase the risk of fire because they produce greater biomass than native grass species (Cox et al., 1990; Anable et al., 1992). The fire resiliency and aggressive nature of this genus presents a risk of a positive feedback of the proliferation of African love-grass and heightened intensity of fire (Anable et al., 1992). 


\subsection{Area of Interest}

Sierra La Mojonera is a natural protected area containing 9,201 hectares located on the border between the states of San Luis Potosí and Zacatecas in a region known as the 'altiplano' or high-plains of northern Mexico (Comisión Nacional de Áreas Naturales Protegidas, 1981). The region of the altiplano is located in the southeastern edge of the Chihuahua desert (Figure 2). Sierra La Mojonera contains a wealth of natural resources. Within the region there are roughly 25 endangered floral species and 7 endangered faunal species. Several different types of shrub and grassland vegetation types are present in SLM to support the variety of flora and fauna. In fact, this southeastern most portion of the Chihuahua desert is perceived as the quintessential example of cacti diversity. The region once provided a refuge from extreme climatic changes, which allowed for an array of speciation events (Rzedowski, 1991). The result was a high level of biological diversity and endemism in species, in particular cacti (Oldfield, 1997). The region is now considered one of the richest and oldest centers of plant evolution and speciation within all of North America (Johnston, 1977). 


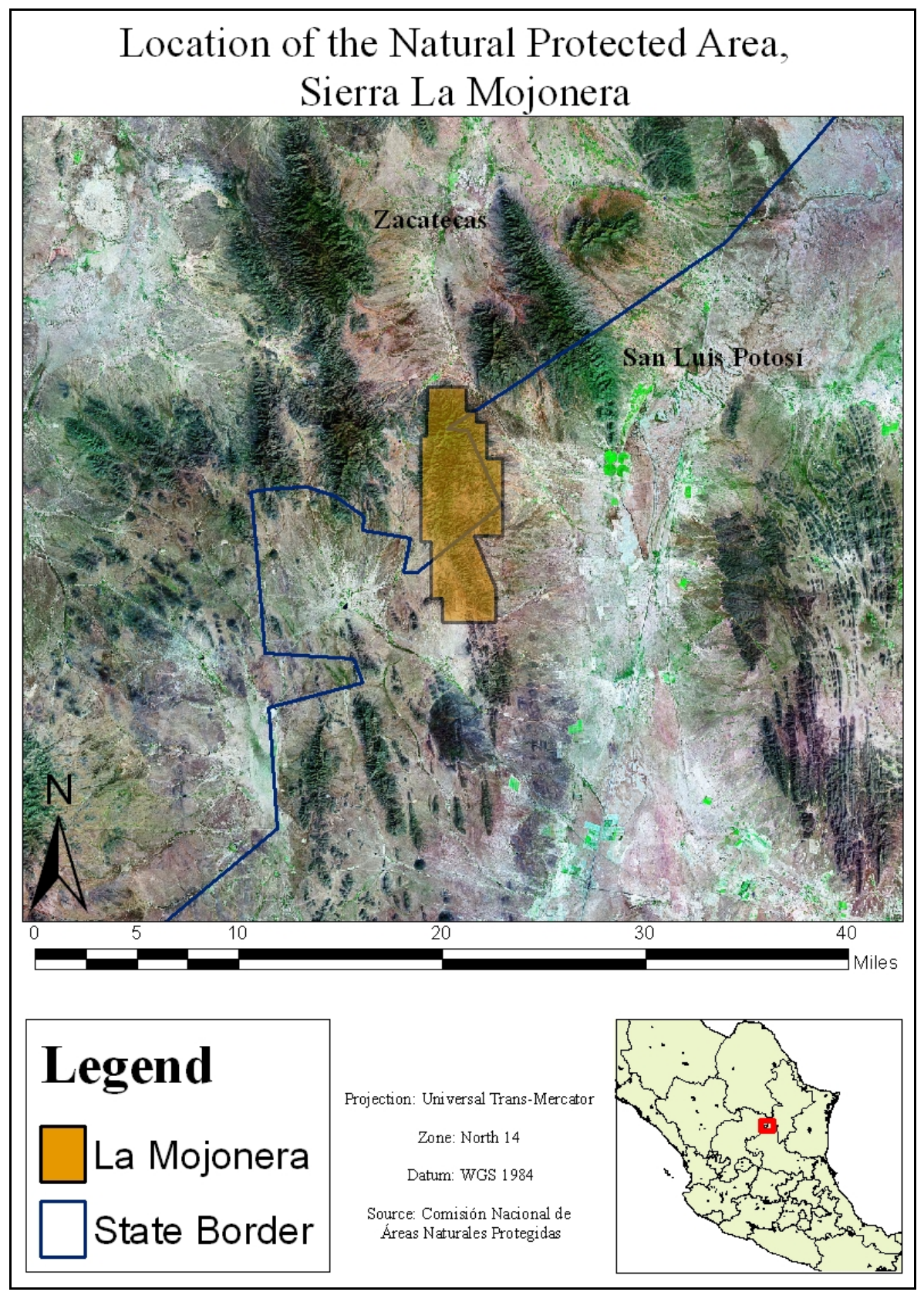

Figure 2: Map of the Natural Protected Area, SLM.

The altiplano region receives a mere $300-500 \mathrm{~mm}$ (11.75in. $-19.75 \mathrm{in}$.) of rainfall annually, with the majority of the precipitation coming in the summer months (Instituto Nacional de Estadística y Geografía, 2009). Subsequently, January through May is considered the dry season throughout the Chihuahua desert region in Mexico. During this period, many wildfires occur throughout the Mexican Chihuahua desert. 


\subsection{Current Environmental Management}

The SLM is managed by the Matehuala regional office of the Comisión Nacional de Áreas Naturales Protegidas (CONANP). The CONANP is a Mexican government agency under the advisement of the Secretaría de Medio Ambiente y Recursos Naturales (CONANP, 2011). The objective of CONANP is to manage the country's natural protected areas with an aim of reducing poverty and marginalization of rural communities present within the natural protected areas (CONANP, 2011). Although there are no inhabitants living within the borders of the SLM natural protected area, the land is jointly owned by 8 different ejidal communities. These ejidal communities live just outside of the natural protected area, but retain the property ownership and a voice in the management decisions carried out by CONANP for the SLM natural protected area. Ejidal land is land that was granted to individual communities by the Mexican government, but the government still retains legal ownership of the land (Hudson, 1991). The complicated and dynamic laws of ejido land can make management decisions difficult, but guarantees the ejido communities maintain a voice in land management decisions as well as employment opportunities through Temporary Employment Projects (PET) in the SLM natural protected area.

The CONANP carries out various PET projects designed to fulfill the objective of managing the SLM natural protected area. These projects are designed by the CONANP office and executed by members of the ejido communities. One of the main PET projects that are carried out every year is the development of firebreaks to mitigate the effects of wildfire. 
There are currently three different ejidos that are involved with projects to construct firebreaks. These same ejidos are involved in monitoring projects to spot the potential outbreak of fire. Table 1 provides a summary of past PET projects and their respective financial budget.

\begin{tabular}{|c|c|c|c|c|}
\hline Year & $\begin{array}{c}\text { Community } \\
\text { (Ejido) }\end{array}$ & Project type & $\begin{array}{c}\text { Financial allocation } \\
\text { (MXN pesos) }\end{array}$ & $\begin{array}{c}\text { Financial allocation } \\
\text { (US Dollars) }\end{array}$ \\
\hline 2010 & El Gallo & $\begin{array}{l}\text { Construction of } \\
\text { firebreaks and fire } \\
\text { monitoring }\end{array}$ & $139,270.08$ & $11,605.00$ \\
\hline 2010 & Huertecillas & $\begin{array}{l}\text { Construction of } \\
\text { firebreaks and fire } \\
\text { monitoring }\end{array}$ & $185,693.43$ & $15,474.00$ \\
\hline 2010 & Los Encinos & $\begin{array}{l}\text { Construction of } \\
\text { firebreaks and fire } \\
\text { monitoring }\end{array}$ & $139,270.08$ & $11,605.00$ \\
\hline 2011 & El Gallo & $\begin{array}{l}\text { Construction of } \\
\text { firebreaks and fire } \\
\text { monitoring }\end{array}$ & $144,000.00$ & $12,000.00$ \\
\hline 2011 & Huertecillas & $\begin{array}{c}\text { Construction of } \\
\text { firebreaks and fire } \\
\text { monitoring }\end{array}$ & $192,000.00$ & $16,000.00$ \\
\hline 2012 & Huertecillas & $\begin{array}{l}\text { Construction of } \\
\text { firebreaks and fire } \\
\text { monitoring }\end{array}$ & $198,866.00$ & $16,572.00$ \\
\hline 2012 & Los Encinos & $\begin{array}{c}\text { Construction of } \\
\text { firebreaks and fire } \\
\text { monitoring }\end{array}$ & $149,142.00$ & $12,428.00$ \\
\hline 2012 & El Tepetate & $\begin{array}{l}\text { Construction of } \\
\text { firebreaks and fire } \\
\text { monitoring }\end{array}$ & $149,142.00$ & $12,428.00$ \\
\hline
\end{tabular}

Table 1: Summary of projects and financial allocations for wildfire projects in the SLM natural protected area.

Current wildfire management decisions for the SLM are executed rather haphazardly. For each firebreak constructed there is a meeting conducted between the CONANP office and voluntary participants of the participating ejido community. Meetings generally last 2 hours to determine the general location and length of the 
firebreak. During this meeting a small group of men is also selected to provide fire vigilance for the SLM natural protected area.

The location and length of firebreaks are usually chosen based on accessibility and simplicity of construction. This is partly a result of the restrictive budget, but more importantly because of the lack of knowledge about best management practices within the discipline of wildfire management. These meetings are also centralized on the ideology of complete fire removal from the ecosystem due to catastrophic wildfires in the past. However, the continued suppression of fire from the ecosystem may be exacerbating catastrophic incidences of fire.

\subsection{Proposed Environmental Management}

Assessing fire behavior and risks can be very difficult because of heterogeneity in topography, vegetation types, and climate (Keane et al., 1998). Fire behavior is highly dependent upon changes in slope, aspect, fuel, and weather conditions (Ibid). The use of GIS technologies and fire modeling software can be used to assess the characteristics of fire based on environmental variables for best management practices in the field of fire management.

\subsection{Fire Modeling Programs}

Currently, there is a number of popular fire modeling programs available that incorporate various fire-spread models (Andrews, 2007). The point model is utilized in the Behave and BehavePLUS fire model programs. The Behave models and its point model are considered to be the most simplified programs because they do not track fire behavior over time or space (Andrews, 2012). As a result, several fire-models were 
released that feature the cellular automata $(\mathrm{CA})$ model to compensate for shortcoming in the point model.

The CA model has become the most commonly used model to simulate fire growth in fire modeling (Bodrožić, 2005). In this model, a two-dimensional rectangular matrix represents the fire model landscape (Kourtz \& O'Regan, 1971; Kourtz et al., 1977). Each cell within the landscape is analyzed as having homogenous conditions. Fire spread occurs from the transition from one burning cell to eight neighboring cells in a rectangular grid. Fire spread is thus limited to 8 directions and always results in an octagonal fire shape (Fire Research \& Management Exchange System, 2010). The cellular model simulates fire growth as a discrete process of individual ignitions across a regularly spaced grid landscape (Finney, 1998). The theory of percolation is used for calculating probabilities of transition in CA models (Kourtz \& O'Regan, 1971; Kourtz et al., 1977). The CA model is limited in its ability to accurately model the curve shape of fire-fronts due to its raster format. Moreover, current CA programs available, like those shown in Table 2, track fire behavior spatially, but do not track fire behavior over time and assume weather conditions are fixed (Bodrožić, 2005). 


\begin{tabular}{|c|c|c|c|c|c|c|c|}
\hline System & $\begin{array}{c}\text { Condition } \\
\text { (Variation } \\
\text { in time) }\end{array}$ & $\begin{array}{c}\text { Condition } \\
\text { (Variation } \\
\text { in space) }\end{array}$ & $\begin{array}{c}\text { Duration } \\
\text { specification }\end{array}$ & Input & Modeling & Output & $\begin{array}{l}\text { Computer } \\
\text { access }\end{array}$ \\
\hline $\begin{array}{l}\text { Behave } \\
\text { PLUS }\end{array}$ & Constant & Uniform & $\begin{array}{c}\text { Elapsed time } \\
\text { for size or } \\
\text { spread } \\
\text { distance }\end{array}$ & $\begin{array}{l}\text { Interactive } \\
\text { user input; } \\
\text { generally } \\
\text { ranges of } \\
\text { values }\end{array}$ & $\begin{array}{c}\text { Separate, } \\
\text { independent } \\
\text { calculation } \\
\text { for each cell } \\
\text { of a table or } \\
\text { point on a } \\
\text { graph }\end{array}$ & $\begin{array}{c}\text { Tables, } \\
\text { graphs, simple } \\
\text { diagrams }\end{array}$ & $\begin{array}{l}\text { Personal } \\
\text { computer }\end{array}$ \\
\hline FlamMap & Constant & $\begin{array}{l}\text { Variable } \\
\text { across the } \\
\text { landscape }\end{array}$ & $\begin{array}{c}\text { No time } \\
\text { duration in } \\
\text { the modeling }\end{array}$ & $\begin{array}{c}\text { Spatial (GIS) } \\
\text { fuel and } \\
\text { terrain data }\end{array}$ & $\begin{array}{c}\text { Separate, } \\
\text { independent } \\
\text { calculation } \\
\text { for each } \\
\text { point/pixel } \\
\text { on the } \\
\text { landscape } \\
\end{array}$ & $\begin{array}{l}\text { Map of } \\
\text { potential fire } \\
\text { behavior for } \\
\text { every point on } \\
\text { the landscape }\end{array}$ & $\begin{array}{l}\text { Personal } \\
\text { computer }\end{array}$ \\
\hline FARSITE & $\begin{array}{l}\text { Vary } \\
\text { diurnally } \\
\text { and by } \\
\text { day }\end{array}$ & $\begin{array}{l}\text { Variable } \\
\text { across the } \\
\text { landscape }\end{array}$ & $\begin{array}{l}\text { Hours/days } \\
\text { of active } \\
\text { burning. }\end{array}$ & $\begin{array}{l}\text { Spatial } \\
\text { (GIS), fuel, } \\
\text { terrain, etc. } \\
\text { data }\end{array}$ & $\begin{array}{c}\text { Fire growth } \\
\text { simulation }\end{array}$ & $\begin{array}{l}\text { Maps of fire } \\
\text { growth, } \\
\text { perimeter, } \\
\text { intensity, etc. }\end{array}$ & $\begin{array}{l}\text { Personal } \\
\text { computer }\end{array}$ \\
\hline FSPro & $\begin{array}{c}\text { Vary by } \\
\text { day }\end{array}$ & $\begin{array}{l}\text { Variable } \\
\text { across the } \\
\text { landscape }\end{array}$ & $\begin{array}{l}\text { Hours/days } \\
\text { of active } \\
\text { burning }\end{array}$ & $\begin{array}{l}\text { User-defined } \\
\text { fuel moisture } \\
\text { and wind }\end{array}$ & $\begin{array}{c}\text { Fuel } \\
\text { moisture and } \\
\text { wind } \\
\text { sequences } \\
\text { from } \\
\text { climatology }\end{array}$ & $\begin{array}{c}\text { Map of } \\
\text { probability of } \\
\text { the fire } \\
\text { reaching each } \\
\text { point by the } \\
\text { end of the } \\
\text { simulation } \\
\text { period }\end{array}$ & $\begin{array}{l}\text { 'High end' } \\
\text { computers } \\
\text { with internet } \\
\text { access by } \\
\text { authorized } \\
\text { analysts }\end{array}$ \\
\hline
\end{tabular}

Table 2: Summary of BehavePLUS, FlamMap, and FSPro fire modeling programs that use the CA surface fire growth model (Andrews, 2007). FARSITE included for comparison. 
The shortcomings of the CA model are answered by the incorporation of the Huygen's Principle (Finney, 1998). The CA model and its raster format are largely unsuccessful in reproducing two-dimensional shapes and growth patterns when the environmental variables become heterogeneous (Finney, 1998; French, 1992). In particular, the cellular model is inadequate in responding to environmental variables in a temporal manner, e.g. shift in wind speed. The number of neighboring cells can be increased to improve the fire shape, but the distortion will still remain (Fire Research \& Management Exchange System, 2010). The Huygen's Principle provides the vector or wave approach in which the fire front is propagated as a continuously expanding fire polygon (Anderson et al., 1982). Ultimately, the Huygen's Principle uses the fire environment at each vertex of the fire perimeter to dimension an elliptical fire wavelet at each time-step. Therefore, at each vertex the fire front is assumed to be independent of all others (Finney, 1998). The vector approach eliminates the need to estimate fire spread to the nearest cell. In the model, wind and slope vectors determine fire direction and shape while the size is determined by the spread rate and time-step (Finney, 1998).

Currently, FARSITE, FSPro, and Prometheus (Tymstra et al., 2010) fire models utilize the Huygen's Principle. FSPro provides all the same capabilities as FARSITE, but requires resources that were unattainable for this study. Prometheus uses the Canadian Forest Fire Danger Rating System, which uses vegetation-types in Canada. FARSITE uses the National Fire Danger Rating Systems and fire behavior prediction fuel models, which were developed by Rothermel (1972) using vegetation-types in the United States. Subsequently, FARSITE was chosen for this study as it contains fuel models for the Chihuahua desert. 


\subsection{FARSITE Fire Simulator}

The FARSITE system is the best fire modeling software because it attempts to integrate the many aspects of fire behavior into an all encompassing fire modeling program (Finney, 1998). By using terrain, weather, and fuel data to model fire spread through space and time, FARSITE provides unparalleled modeling opportunities. Moreover, FARSITE simulates models for surface fire spread (Rothermel, 1972), crown fire spread (Van Wagner, 1977), spotting (Albini, 1979), point source acceleration, and fuel moisture (Finney, 1998).

The FARSITE program can be used for simulations of past fires, simulation of current fires, or simulation of potential fires (Finney, 1994). Subsequently, FARSITE has been used to carry out a variety of different research objectives. Some applications include fire succession models (Keane et al., 1999), quantifying the difference between historic and current fire spread (Duncan \& Schmalzer, 2004), and assessing the effect of silvicultural and fuel treatments on potential fire behavior (Stephens, 1998). The FARSITE program has become one of the most widely used in the world and is the model used by many land management agencies in the United States, including the US Forest Service (Keane et al., 2000).

\subsubsection{Limitations}

Despite the efficacy of producing accurate fire models, the FARSITE modeling program contains several limitations. These limitations are largely the result of the assumptions the program makes when producing models. These assumptions are made throughout different algorithms of the FARSITE modeling program. 
The open wind data provided for the model are assumed to run parallel to the terrain and are assumed spatially constant. However, these values can vary in both speed and direction over time. Similarly, daily precipitation values are assumed to be uniform across the landscape.

Weather input data requires daily maximum and minimum temperature and humidity. The temperature and humidity observations are interpolated with a sine-curve (Rothermel et al., 1986). Thus, the model assumes maximum temperature and minimum humidity are coincident. Although it is likely true for most circumstances, it is likely incorrect during times of precipitation.

As previously mentioned, FARSITE uses the Huygen's Principle to simulate fire growth. The model assumes the pattern of fire spread is an elliptical wave (Finney, 1998). Previous studies suggest that this model is fairly accurate in homogenous conditions (Anderson et al., 1982; French, 1992) and in complex conditions (Sanderlin \& Sunderson, 1975). However, other studies suggest that FARSITE over-predicts the spread of fire (Rothermel, 1972). The problem may be contributed to inaccuracies within fuel moistures, fuel descriptions, and weather inputs. These inaccuracies may have the tendency to overestimate fire spread rate (Finney, 1998). The problem may be exacerbated with the following problem with the fire spread model; fire arrival and spread at a given point within the landscape are dependent upon the behavior and travel time en route to that particular location (Finney, 1998). Subsequently, any errors will accrue over distance and time within the model (Ibid). These errors will occur regardless of the accuracy in spatial and temporal data, but may become magnified by input errors (Ibid). 
Another limitation with FARSITE is the homogeneity within the fuel model. The model assumes each fuel model is homogenous and ignores potential variations (Finney, 1998). Therefore, if there is a discontinuity in fuel within the landscape, e.g. a large rock outcropping, the FARSITE model will not recognize this discrepancy. Also, the accuracy of the fuel model is highly dependent upon the accuracy of the fuel map (Massada et al., 2009). When fuel maps are not accurate, there is a large margin of error within the results (Ibid). It is therefore up to the user to assign fuel models that are spatially accurate and represent the proper land cover type.

\subsection{Previous FARSITE Studies}

The designing of a prescribed burn is a principal objective for many land managers when it comes to fire planning. The FARSITE output can be a very useful tool in the design of controlled burns as it was designed for planning and management of these fires (Finney, 1994). In fact, Finney and Andrews affirm that fire planning was the original objective and remains to be the most commonly used application for FARSITE (1999). A study by Omi et al. (1999) assessed the cost effectiveness of prescribed fires by developing a fuel model for before the implementation of prescribed fire treatments and after. Fire simulations through FARSITE estimated the difference in fire intensity and evaluate the effectiveness of prescribed fire (Omi et al., 1999). The results were used to guide all prescribed burning by land management agencies under the Department of Interior. FARSITE has also been used in several other studies to assist the planning of prescribed burns (Stratton, 2004).

Prescribed burns are a great way to reduce hazardous fuels, but other fuel reduction measures are often necessary. Fuel treatments are another common and highly 
effective tool to minimize fire hazard. Fuel treatments are considered to be any kind of change in the spatial arrangement of fuel to retard or cease the propagation of fire (Duguy et al., 2007). Common fuel treatments include the creation of water points, firebreaks, or various techniques of vegetative thinning (Van Wagtendonk, 1996; Stephens, 1998). Firebreaks have proven to be one of the most adequate and cost effective fuel management techniques (Mansourian, 2005; Finney 2001). The FARSITE model has proven to be an effective tool for testing and implementing effective fuel treatments (Van Wagtendonk, 1996; Stephens, 1998). There is no absolute standard for firebreak width or location as a consequence of variation in topography, prevailing winds, and vegetation. However, the use of FARSITE is an ideal program to test and implement the most effective firebreaks for a particular location (Mansourian, 2005). A FARSITE study conducted by Duguy et al. (2007) in the Spanish Mediterranean found firebreaks to be highly effective in the reduction of fire size. The study also suggested that FARSITE was a highly effective model for testing fuel treatments, including firebreaks.

The scope of FARSITE also includes the evaluation of fuels in their normal state within an ecosystem (Finney, 2001; Stephens, 1998; Stratton, 2004; Van Wagtendonk, 1996). One can use FARSITE to compare fire characteristics between various vegetation types and assess their relative fire risk. In a study by Yang et al. (2008) fuel/vegetation models were derived for different vegetation types within the Missouri Ozark Highlands of the Mark Twain National Forest. These fuel models were used to estimate fire behavior and determine which vegetation types are most susceptible to fire. The study by Yang et al. (2008) was used to help the U.S. Forest Service prioritize fire risks with 
National Forests. The findings revealed that vegetation type was one of the largest drivers on fire spread and intensity.

Mistry and Berardi (2005) in the Brazilian savanna used FARSITE to simulate

fire behavior in the dry season using FARSITE. The focus was to identify the relative risk of vegetation types, particularly during the high-risk dry season (Ibid). The majority of fires within the Brazilian savanna occur within a 3-month extreme dry season. Similarly, another study by Massada et al. (2009) aimed to identify the effect of extreme weather conditions on fire risk along the wildland urban interface of Wisconsin. In both of these studies the results were quite evident that seasonality and extreme weather conditions greatly increased the risk and severity of fire. Findings like these suggest the importance of evaluating seasonality on fire behavior and management.

\section{CHAPTER 3}

\section{RESEARCH METHODOLOGY}

\subsection{FARSITE Data Inputs}

Various fire simulation models can be used in tandem with GIS technologies to simulate various characteristics of a fire. The Program FARSITE, developed by Finney (1994), is a fire behavior and fire growth simulator program that incorporates both spatial and temporal information on topography, fuels, and weather.

As shown in Figure 3, the required spatial data inputs include elevation, slope, aspect, fuel model and canopy cover. Optional spatial data includes crown height, crown base height, and crown bulk density (Finney, 1998). All of these data need to be created as GIS raster themes. Elevation, slope, and aspect can be derived from a digital elevation 
model (DEM). Elevation data are used to calculate temperature and humidity via a computer algorithm throughout the entire landscape. Slope is used to calculate the rate of fire spread, while aspect is used to determine the incident solar radiation as well as transforming spread rates and directions from the surface landscape (Finney, 1998). The fuel model provides a physical description of the fuel within the landscape at the surface level. Canopy cover is used to determine the shading of surface level fuels. These values also affect the fuel moisture calculations and are used to reduce wind speed values (Albini \& Baughman, 1979). Crown height affects wind reduction in a similar manner and also determines starting point and trajectory of embers lofted by torching trees (Albini, 1979). Crown base height is used to determine the transition of fire from surface to crown fire (Van Wagner, 1977). Crown bulk density is used to determine the threshold for achieving an active crown fire (Ibid). When these files are overlapped, it attempts to create a digital representation of all real world spatial characteristics.

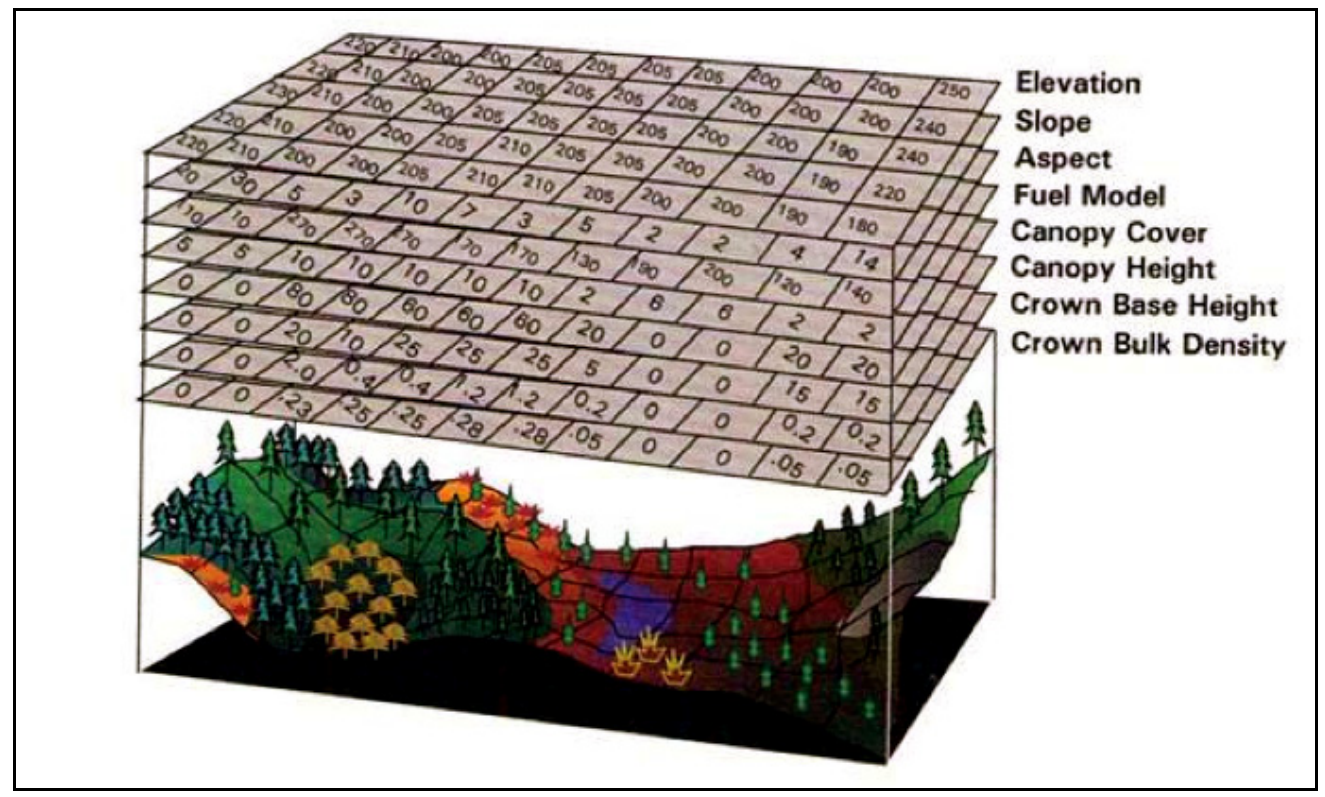

Figure 3: The five required and three optional spatial data files used in FARSITE (National Wildfire Coordinating Group, 2010). 
Weather data inputs require daily observations of minimum and maximum temperature, minimum and maximum humidity, precipitation and the elevation of recorded values as shown in Table 3 . These values are used to create a diurnal weather pattern throughout the landscape and determine the fuel moistures (Finney, 1998).

\begin{tabular}{|c|c|c|c|c|c|c|c|c|c|}
\hline & & & \multicolumn{2}{|c|}{ Hour } & \multicolumn{2}{|c|}{ Temperature } & \multicolumn{2}{|c|}{$\begin{array}{l}\text { Relative } \\
\text { Humidity }\end{array}$} & \multirow[b]{2}{*}{ Elevation } \\
\hline Month & Day & PPT & AM & PM & Min & Max & Max & Min & \\
\hline & & $* 100$ & & & \multicolumn{2}{|c|}{${ }^{\circ} \mathrm{C}$} & \multicolumn{2}{|c|}{ Percent } & Meters \\
\hline 7 & 19 & 0 & $6: 00$ & $15: 00$ & 9 & 26 & 65 & 28 & 1700 \\
\hline 7 & 20 & 0 & $6: 00$ & $15: 00$ & 10 & 27 & 62 & 25 & 1700 \\
\hline 7 & 21 & 0 & $6: 00$ & 15:00 & 9 & 25 & 54 & 27 & 1700 \\
\hline 7 & 22 & 10 & $6: 00$ & $15: 00$ & 8 & 26 & 57 & 31 & 1700 \\
\hline 7 & 23 & 0 & $6: 00$ & $15: 00$ & 12 & 23 & 58 & 26 & 1700 \\
\hline 7 & 24 & 0 & $6: 00$ & $15: 00$ & 9 & 27 & 57 & 27 & 1700 \\
\hline
\end{tabular}

Table 3: Required weather data format for FARSITE (Finney, 1998).

Temperature and humidity values are assumed to have an inverse relationship and are calculated via a cosine curve as shown in Table 4 (Rothermel et al., 1986). The user provides the daily maximum and minimum values, represented by the dots in Table 4 . These maximum and minimum values are then used to extrapolate all other temperature and humidity values. Temperature values are extrapolated throughout the landscape at a rate of $-1{ }^{\circ} \mathrm{C}$ per $100 \mathrm{~m}$ in elevation from the reference point. Humidity values are also extrapolated throughout the landscape, but derived from temperature values at a rate of $0.2 \%$ per 100 meters. The model of temperature/humidity interpolation and lapse rates are fixed algorithms within the FARSITE model (Rothermel et al., 1986). 


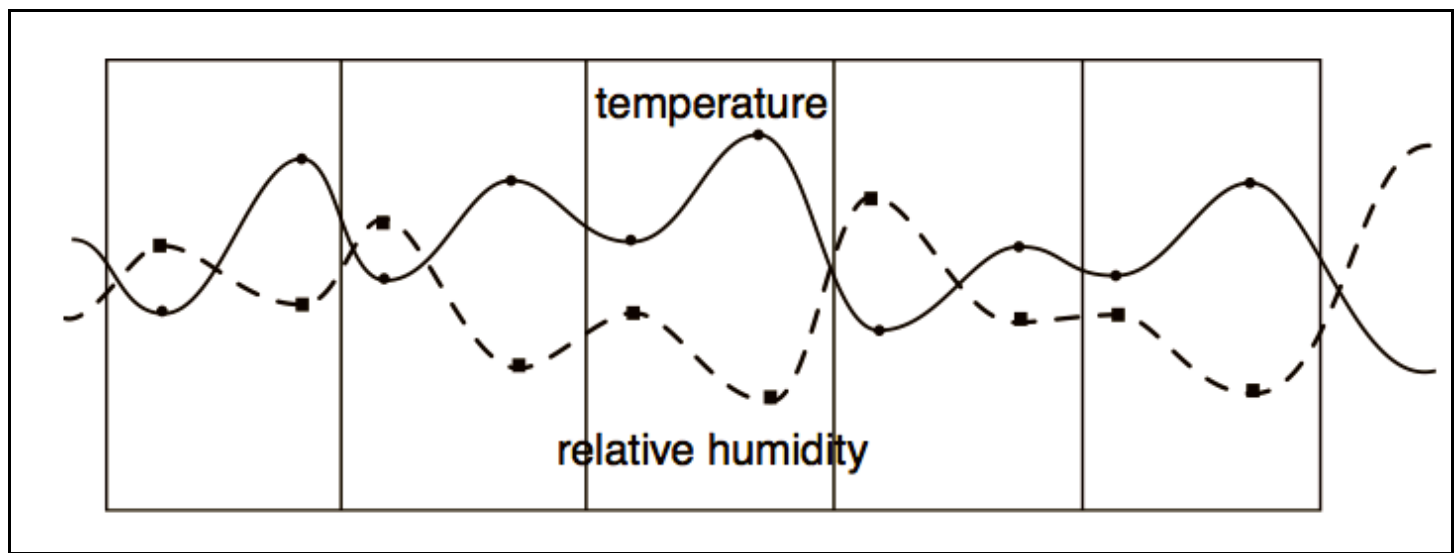

Table 4: Inverse pattern of temperature and relative humidity showing cosine interpolation over a 5-day period (Finney, 1998).

Wind data require values for open wind speed, wind direction, and cloud cover as shown in Table 5. Open wind speed and wind direction are used in the calculation of fire spread rate and direction, respectively (Finney, 1998). Cloud cover is used in tandem with canopy cover to determine solar irradiance (Ibid). These values are assumed to be uniform through the landscape just like the weather data.

\begin{tabular}{|c|c|c|c|c|c|}
\hline Month & Day & $\begin{array}{c}\text { Hour, } \\
\text { minute }\end{array}$ & $\begin{array}{c}\text { Open Wind } \\
\text { Speed }\end{array}$ & $\begin{array}{c}\text { Wind } \\
\text { Direction }\end{array}$ & Cloud cover \\
\hline & & & $(\mathrm{km} / \mathrm{h})$ & $\left({ }^{\circ} \mathrm{Az}\right)$ & (Percent) \\
\hline 6 & 27 & $0: 00$ & 0 & 65 & 0 \\
\hline 6 & 27 & $2: 00$ & 5 & 72 & 0 \\
\hline 6 & 27 & $3: 00$ & 6 & 74 & 0 \\
\hline 6 & 27 & $4: 00$ & 0 & 86 & 0 \\
\hline 6 & 27 & $5: 00$ & 10 & 127 & 20 \\
\hline 6 & 27 & $6: 00$ & 15 & 246 & 40 \\
\hline 6 & 27 & $7: 00$ & 17 & 224 & 10 \\
\hline
\end{tabular}

Table 5: Required wind data format for FARSITE (Finney, 1998).

The accuracy of the input data layers is very important for realistic predictions of fire growth (Keane et al., 1998; Finney, 1998). The fuel model is the key input for a FARSITE simulation and is often the most difficult dataset to obtain for fire managers. Many studies suggest that the fuel model accuracy is the limiting factor in the efficacy of 
wildfire modeling (Miller \& Yool, 2002; Arroyo et al., 2008; Mutlu et al., 2008; Finney, 1998). The FARSITE program uses the Rothermel fuel model, which was developed in 1968 and simulates fire spread at surface levels (Table 6), and the Huygens' principle (Richards, 1990) for calculating surface spread pattern.

The Rothermel fuel model (1972) uses the Northern Forest Fire Laboratory (NFFL) standardized fuel models that were designed in the middle 1970's (Albini, 1976). It is still one of the most commonly used fuel models and is used by a great deal of fire modeling programs, including FARSITE. The fuel model was composed of the original 13 different fuel types, which were designed for applications in the United States. Each fuel type classification is exclusively suitable for use in the same geographic location and should not be used out of context. Previous studies have revealed that when a fuel type has been adopted for use in a foreign system the results have been poor (Arroyo, 2008). In 2005, an additional 40 fuel models were created in part to increase the demand for fuel models in various fire behavior regions as shown in Table 6 .

\begin{tabular}{|c|c|c|c|c|c|c|c|c|c|c|c|}
\hline \multirow{2}{*}{$\begin{array}{l}\text { Fuel } \\
\text { Model } \\
\text { Code }\end{array}$} & \multicolumn{5}{|c|}{ Fuel load (t/ac) } & \multicolumn{3}{|c|}{$\mathrm{SAV}$ ratio $(1 / \mathrm{ft})$} & \multirow{2}{*}{$\begin{array}{c}\begin{array}{c}\text { Fuel } \\
\text { bed } \\
\text { depth }\end{array} \\
(\mathrm{ft})\end{array}$} & \multirow{2}{*}{$\begin{array}{c}\begin{array}{c}\text { Dead } \\
\text { fuel } \\
\text { moisture }\end{array} \\
\text { (percent) }\end{array}$} & \multirow{2}{*}{$\begin{array}{c}\begin{array}{c}\text { Heat } \\
\text { conten } \\
t\end{array} \\
\begin{array}{c}\text { (BTU/ } \\
\text { lb) }\end{array}\end{array}$} \\
\hline & $\begin{array}{l}1- \\
\mathrm{hr}\end{array}$ & $\begin{array}{l}10- \\
\mathrm{hr}\end{array}$ & $\begin{array}{l}100 \\
-\mathrm{hr}\end{array}$ & $\begin{array}{l}\text { Live } \\
\text { herb }\end{array}$ & $\begin{array}{c}\text { Live } \\
\text { wood }\end{array}$ & $\begin{array}{c}\text { Dead } \\
1-h r\end{array}$ & $\begin{array}{l}\text { Live } \\
\text { herb }\end{array}$ & $\begin{array}{c}\text { Live } \\
\text { wood }\end{array}$ & & & \\
\hline GR1 & $\begin{array}{l}0 . \\
1 \\
\end{array}$ & 0 & 0 & 0.3 & 0 & 2200 & 2000 & 9999 & 0.4 & 15 & 8000 \\
\hline GR2 & $\begin{array}{l}0 . \\
1 \\
\end{array}$ & 0 & 0 & 1 & 0 & 2000 & 1800 & 9999 & 1 & 15 & 8000 \\
\hline GR3 & $\begin{array}{c}0 . \\
1 \\
\end{array}$ & 0.4 & 0 & 1.5 & 0 & 1500 & 1300 & 9999 & 2 & 30 & 8000 \\
\hline GR4 & $\begin{array}{l}0 . \\
25 \\
\end{array}$ & 0 & 0 & 1.9 & 0 & 2000 & 1800 & 9999 & 2 & 15 & 8000 \\
\hline GR5 & $\begin{array}{l}0 . \\
4\end{array}$ & 0 & 0 & 2.5 & 0 & 1800 & 1600 & 9999 & 1.5 & 40 & 8000 \\
\hline GR6 & $\begin{array}{l}0 . \\
1\end{array}$ & 0 & 0 & 3.4 & 0 & 2200 & 2000 & 9999 & 1.5 & 40 & 9000 \\
\hline GR7 & 1 & 0 & 0 & 5.4 & 0 & 2000 & 1800 & 9999 & 3 & 15 & 8000 \\
\hline GR8 & $\begin{array}{c}0 . \\
5\end{array}$ & 1 & 0 & 7.3 & 0 & 1500 & 1300 & 9999 & 4 & 30 & 8000 \\
\hline
\end{tabular}




\begin{tabular}{|c|c|c|c|c|c|c|c|c|c|c|c|}
\hline GR9 & 1 & 1 & 0 & 9 & 0 & 1800 & 1600 & 9999 & 5 & 40 & 8000 \\
\hline GS1 & $\begin{array}{l}0 . \\
2\end{array}$ & 0 & 0 & 0.5 & 0.65 & 2000 & 1800 & 1800 & 0.9 & 15 & 8000 \\
\hline GS2 & $\begin{array}{l}0 . \\
5\end{array}$ & 0.5 & 0 & 0.6 & 1 & 2000 & 1800 & 1800 & 1.5 & 15 & 8000 \\
\hline GS3 & $\begin{array}{l}0 . \\
3\end{array}$ & 0.25 & 0 & 1.45 & 1.25 & 1800 & 1600 & 1600 & 1.8 & 40 & 8000 \\
\hline GS4 & $\begin{array}{l}1 . \\
9\end{array}$ & 0.3 & 0.1 & 3.4 & 7.1 & 1800 & 1600 & 1600 & 2.1 & 40 & 8000 \\
\hline SH1 & $\begin{array}{c}0 . \\
25\end{array}$ & 0.25 & 0 & 0.15 & 1.3 & 2000 & 1800 & 1600 & 1 & 15 & 8000 \\
\hline $\mathrm{SH} 2$ & $\begin{array}{l}1 . \\
35\end{array}$ & 2.4 & 0.75 & 0 & 3.85 & 2000 & 9999 & 1600 & 1 & 15 & 8000 \\
\hline SH3 & $\begin{array}{l}0 . \\
45\end{array}$ & 3 & 0 & 0 & 6.2 & 1600 & 9999 & 1400 & 2.4 & 40 & 8000 \\
\hline SH4 & $\begin{array}{c}0 . \\
85\end{array}$ & 1.15 & 0.2 & 0 & 2.55 & 2000 & 1800 & 1600 & 3 & 30 & 8000 \\
\hline SH5 & $\begin{array}{l}3 . \\
6\end{array}$ & 2.1 & 0 & 0 & 2.9 & 750 & 9999 & 1600 & 6 & 15 & 8000 \\
\hline SH6 & $\begin{array}{l}2 . \\
9\end{array}$ & 1.45 & 0 & 0 & 1.4 & 750 & 9999 & 1600 & 2 & 30 & 8000 \\
\hline SH7 & $\begin{array}{l}3 . \\
5\end{array}$ & 5.3 & 2.2 & 0 & 3.4 & 750 & 9999 & 1600 & 6 & 15 & 8000 \\
\hline SH8 & $\begin{array}{l}2 . \\
05\end{array}$ & 3.4 & 0.85 & 0 & 4.35 & 750 & 9999 & 1600 & 3 & 40 & 8000 \\
\hline SH9 & $\begin{array}{l}4 . \\
5\end{array}$ & 2.45 & 0 & 1.55 & 7 & 750 & 1800 & 1500 & 4.4 & 40 & 8000 \\
\hline TU1 & $\begin{array}{l}0 . \\
2\end{array}$ & 0.9 & 1.5 & 0.2 & 0.9 & 2000 & 1800 & 1600 & 0.6 & 20 & 8000 \\
\hline TU2 & $\begin{array}{c}0 . \\
95\end{array}$ & 1.8 & 1.25 & 0 & 0.2 & 2000 & 9999 & 1600 & 1 & 30 & 8000 \\
\hline TU3 & $\begin{array}{l}1 . \\
1\end{array}$ & 0.15 & 0.25 & 0.65 & 1.1 & 1800 & 1600 & 1400 & 1.3 & 30 & 8000 \\
\hline TU4 & $\begin{array}{c}4 . \\
5\end{array}$ & 0 & 0 & 0 & 2 & 2300 & 9999 & 2000 & 0.5 & 12 & 8000 \\
\hline TU5 & 4 & 4 & 3 & 0 & 3 & 1500 & 9999 & 750 & 1 & 25 & 8000 \\
\hline TL1 & 1 & 2.2 & 3.6 & 0 & 0 & 2000 & 9999 & 9999 & 0.2 & 30 & 8000 \\
\hline TL2 & $\begin{array}{l}1 \\
4\end{array}$ & 2.3 & 2.2 & 0 & 0 & 2000 & 9999 & 9999 & 0.2 & 25 & 8000 \\
\hline TL3 & $\begin{array}{c}0 . \\
5\end{array}$ & 2.2 & 2.8 & 0 & 0 & 2000 & 9999 & 9999 & 0.3 & 20 & 8000 \\
\hline TL4 & $\begin{array}{c}0 . \\
5\end{array}$ & 1.5 & 4.2 & 0 & 0 & 2000 & 9999 & 9999 & 0.4 & 25 & 8000 \\
\hline TL5 & $\begin{array}{l}1 . \\
15\end{array}$ & 2.5 & 4.4 & 0 & 0 & 2000 & 9999 & 1600 & 0.6 & 25 & 8000 \\
\hline TL6 & $\begin{array}{r}2 . \\
4 \\
\end{array}$ & 1.2 & 1.2 & 0 & 0 & 2000 & 9999 & 9999 & 0.3 & 25 & 8000 \\
\hline TL7 & $\begin{array}{l}0 . \\
3\end{array}$ & 1.4 & 8.1 & 0 & 0 & 2000 & 9999 & 9999 & 0.4 & 25 & 8000 \\
\hline TL8 & $\begin{array}{l}5 . \\
8\end{array}$ & 1.4 & 1.1 & 0 & 0 & 1800 & 9999 & 9999 & 0.3 & 35 & 8000 \\
\hline TL9 & $\begin{array}{l}6 . \\
65 \\
\end{array}$ & 3.3 & 4.15 & 0 & 0 & 1800 & 9999 & 1600 & 0.6 & 35 & 8000 \\
\hline
\end{tabular}




\begin{tabular}{|c|c|c|c|c|c|c|c|c|c|c|c|}
\hline SB1 & $\begin{array}{r}1 . \\
5\end{array}$ & 3 & 11 & 0 & 0 & 2000 & 9999 & 9999 & 1 & 25 & 8000 \\
\hline SB2 & $\begin{array}{r}4 . \\
5\end{array}$ & 4.25 & 4 & 0 & 0 & 2000 & 9999 & 9999 & 1 & 25 & 8000 \\
\hline SB3 & $\begin{array}{r}5 . \\
5\end{array}$ & 2.75 & 3 & 0 & 0 & 2000 & 9999 & 9999 & 1.2 & 25 & 8000 \\
\hline SB4 & $\begin{array}{r}5 . \\
25\end{array}$ & 3.5 & 5.25 & 0 & 0 & 2000 & 9999 & 9999 & 2.7 & 25 & 8000 \\
\hline
\end{tabular}

Table 6: Extended set of NFFL fire behavior fuel models (Scott, 2005).

\subsection{Methodology of Previous Studies}

According to the literature, essentially all studies use a DEM to define topographic variables such as slope, aspect and elevation (Finney, 1998). A number of studies (Miller \& Yool, 2002; Massada et al., 2009; Stephens, 1998) have used a 30meter DEM because they are highly available, adequately accurate, and generally free of charge. In fact, the National Aeronautics and Space Administration (NASA) have provided a freely available 30-meter DEM via their Advanced Spaceborne Thermal Emission and Reflection Radiometer (ASTER) program for over for 99\% of the globe (Tachikawa et al., 2011).

In early studies efforts to map vegetation and fuel types were carried out through field surveys (Arroyo et al., 2008). These studies have the potential of being highly accurate, but require a great deal of time and man-hours in the field and are cost prohibitive for large areas. With the advancement of technology, most studies use remotely sensed imagery to classify vegetation and fuels (Finney, 1998). Remotely sensed imagery can be analyzed through a supervised classification (Miller \& Yool, 2002; Stratton, 2004), unsupervised classification or a Normalized Difference Vegetation Index, or NDVI (Nonomura et al., 2007), or a combination of these methods to quantitatively classify various fuel types for use in FARSITE. Various satellite images 
including LandSat (Miller \& Yool, 2002), ASTER from NASA (Paz et al., 2011), LIDAR-Quickbird (Mutlu et al., 2008), Systéme Pour l'Observation de la Terre or SPOT (Castro \& Chuvieco, 1998), and others have been used to classify various vegetation types for use in FARSITE. Supervised classifications are recommended because they utilize advancements in remote sensing and technology while maintaining the advantage of having the field researcher in physical contact with the study area (Arroyo et al., 2008). When the researcher is unable to access their study area a non-supervised classification or NDVI should be used. A non-supervised classification allows a computer algorithm to examine the pixels in the image and aggregate them into various classes without training points, provided by the user is (Lillesand et al., 2008). A study by van Wagtendonk and Root used a non-supervised classification to identify 30 vegetation classes in Yosemite National Park (2003). When dealing with a vast area and varied vegetation, a non-supervised classification can yield better results.

The other method known as the NDVI can be very useful for classifying vegetation types. A NDVI is defined by the equation in figure 4. In figure 4, VIS stands for visible light and NIR stand for near infrared of spectral reflectance measurements (Lillesand, 2008). Thus, the NDVI distinguishes various land cover types based on their 'greenness'. This classification is not commonly used for developing fuel models in FARSITE, but was used in a study by Nonomura et al. (2007) to evaluate areas affected by a previous wildfire. A NDVI classification would be appropriate for assessing postfire damage as it assess the infrared reflection of vegetation. Moreover, NDVI helps compensate for alterations from changing illumination conditions such as surface slope, and aspect (Lillesand et al., 2008). 
$\mathrm{NDVI}=\frac{(\mathrm{NIR}-\mathrm{VIS})}{(\mathrm{NIR}+\mathrm{VIS})}$

Figure 4: Equation for calculating NDVI.

Throughout the continental United States, national parks have developed highly accurate land cover analyses and fuel models (Van Wagtendonk, 1997). NFFL fuel models have been mapped across the lower 48 states at 30 -meter resolution through a project known as LANDFIRE (LANDFIRE, 2007). Similar works have been carried out in other countries, such as Brazil, which has derived vegetation and fuel maps compatible for FARSITE (Mistry \& Berardi, 2005). These works streamline the data preparation process for FARSITE. When these sources are not available, the user must decide which fuel model to match each vegetation type or create custom fuel models.

Creating custom fuel models requires collecting data from fire behavior studies (Mistry \& Berardi, 2005). Site-specific fuel models can be created using the programs NEWMDL or TSTMDL, which are sub-models of the BEHAVE fire model (Burgan \& Rothermel, 1984). The program allows the user to input data on the quantity and characteristic of fuels for each vegetation type, which are then used to compute values that can be input into FARSITE (Mistry \& Berardi, 2005). However, this requires considerable data.

In the literature (Stratton, 2004; Mistry \& Berardi, 2005), custom fuel models were developed on the basis of considerable field data, anecdotal observations, and previously published work. As a result, many studies have used the standard fuel models (Schmidt et al., 2008; Massada et al., 2009; Paz et al., 2011; Stratton, 2004). 
Values for canopy cover have been gathered through various methodologies. Most works were developed based on field data, anecdotal observations, and previously published work (Stratton, 2004; Mistry \& Berardi, 2005). However, some works require more accurate values that can be retrieved through remote sensing. In one study, panchromatic digital orthophoto quarter quadrangles (DOQQs) have been used to estimate tree canopy cover (Miller \& Yool, 2002). The process involves the collection of training samples of canopy cover to train the computer algorithm. The process for assessing canopy cover is carried out in much the same way a supervised classification of land cover would be carried out.

Some studies were able to find automated wind and weather data from sources as close as $9 \mathrm{~km}$ from the study area (Schmidt et al., 2008). Meteorological data has been collected by local weather stations (Finney, 1998). Some studies have used multiple weather stations (Miller \& Yool, 2002).

\subsection{Data Collection}

\subsubsection{Topographic Data}

A 30M digital elevation model (DEM) provided by the Instituto Nacional de Estadística y Geografía (INEGI) was used to determine slope, aspect, and elevation.

\subsubsection{Fuel Model}

A 10-meter resolution SPOT multispectral satellite image taken on April 19th, 2008 was used to create a vegetation classification of SLM natural protected area. The image contained 4 bands, which included Red, Green, Blue, and Near Infrared. The image was orthorectified by the distributor, EADS Matra Systems \& Information and registered to the UTM coordinate system: Zone 14 North. 
Next, a radiometric correction was performed to mitigate the effects of atmospheric interferences from the satellite image. The electromagnetic radiation (ER) being captured by the satellite sensor has already passed through the earth's atmosphere twice and has been affected by phenomena known as absorption and scattering. Absorption occurs when ER interacts with gases including water vapor, ozone, and carbon dioxide. Scattering is the result from the interactions between ER and gas molecules and other airborne particulate matter (Cross, 2011). These effects reduce the contrast between pixels and can scatter ER causing values to be skewed by neighboring pixels (Kaufman, 1989).

The process of radiometric correction was performed through a conversion of digital numbers $(\mathrm{DN})$ to spectral radiance and then a conversion of spectral radiance to exoatmospheric reflectance as shown in Figure 5. The calibration from DN to spectral radiance is provided by the following expression for at-satellite spectral radiance,

Equation $1 \mathrm{~L} \lambda=$ Bias $+($ Gain $\mathrm{x}$ DN $)$, where

Bias- Spectral radiance of sensor for a DN of zero Gain- Gradient of the calibration DN- Digital numbers

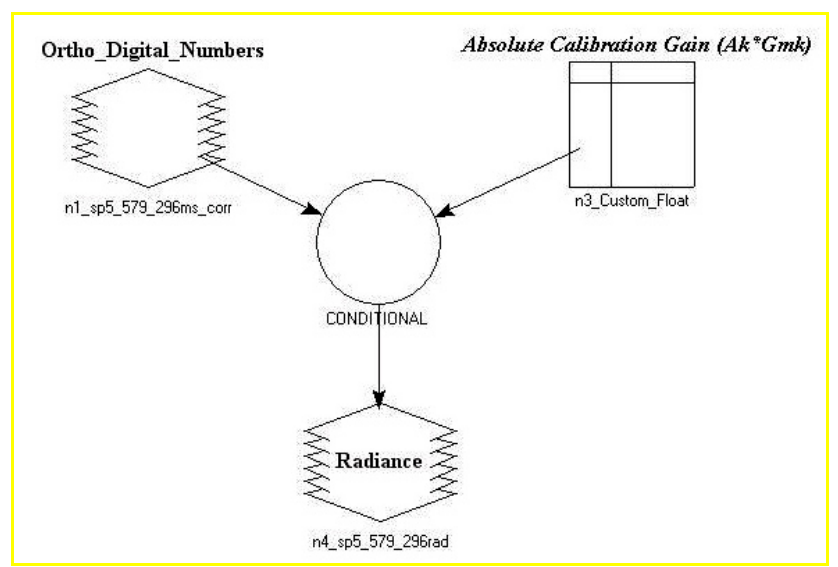

Figure 5: Model created in ERDAS Imagine 9.1 to convert DN values to spectral radiance. 
Exoatmospheric radiation was calculated through a model shown in Figure 6. The conversion of spectral radiance to exoatmospheric reflectance is given in the following expression,

Equation $2 \pi \cdot$ L.d $2 \rho=$ ESUN.cos(SZ), where

$\rho=$ unitless planetary reflectance at satellite (this takes values of $0-1$.) $\pi=3.141593$

$\mathrm{L}=$ Spectral radiance at sensor aperture $(\mathrm{mW} \mathrm{cm}-2$ ster-1 $\mu \mathrm{m}-1)$ $\mathrm{d} 2=$ Earth-Sun distance value squared in astronomical units $\mathrm{ESUN}=$ Mean solar exoatmospheric irradiance $(\mathrm{mW} \mathrm{cm}-2 \mu \mathrm{m}-1)$ $\mathrm{SZ}=$ sun zenith angle at time image was captured

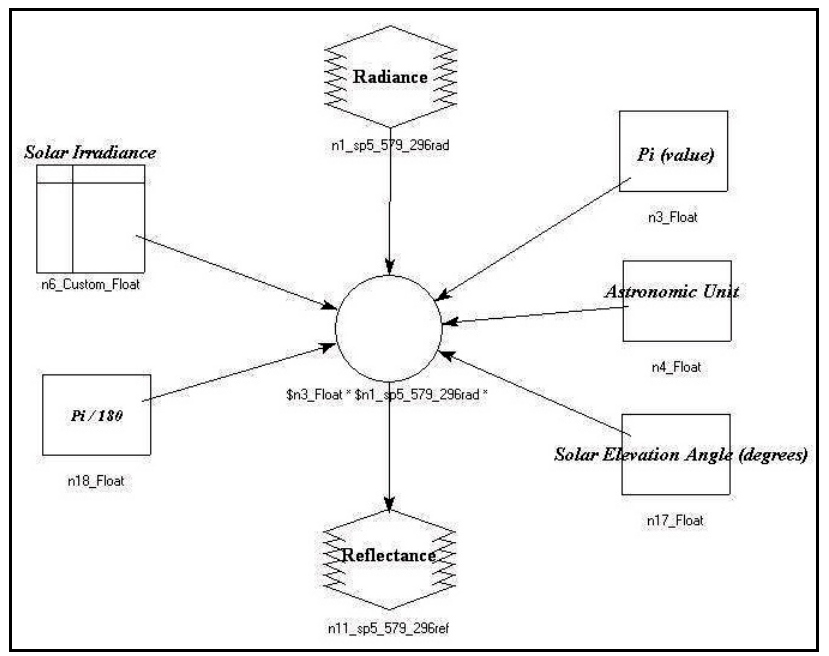

Figure 6: Model created in ERDAS Imagine 9.1 to correct for exoatmospheric reflectance.

Satellite imagery taken in mountainous regions often contains distortions that are referred to as topographic effects. The angle of the sun and the angles from the terrain can lead to changes in illumination and manipulate the brightness values in the satellite image (ERDAS, 1999). Shaded areas will show lower reflectance whereas sunny areas will show higher than expected reflectance. 
A Non-Lambertian model was produced in ERDAS Imagine 9.1 to correct for topographic effects as seen in Figure 7. A Non-Lambertian model known as the Minnaert correction method was used (Smith et al., 1980). The model takes into account that surfaces do not reflect incident solar light uniformly in all directions through the bidirectional reflectance distribution function (BRDF). The BRDF was developed to describe how reflectance varies upon topography in regards to the angle of incidence and observation (Riaño et al., 2003). A Minnaert constant is generated based on the topographic characteristics for each individual application (Murakami, 2007).

Subsequently, this model is more computationally rigorous, but is believed to be the most effective model at reducing the topographic effect on spectral signatures (ERDAS, 1999; Justice et al., 1981; Baker et al., 1991).

A total of 16 iterations were run with varying Minnaert constants. Based on visual interpretation, Minnaert values of 0.5 for all 4 spectral bands were chosen to be the most accurate.

The following equation is the Non-Lambertian Topographic model included in ERDAS Imagine 9.1 (Colby 1991):

Equation $3 \mathrm{BV}_{\text {normal }}=\left(\mathrm{BV}_{\text {observed } \lambda} \cos e\right) /\left(\cos ^{\mathrm{k}} i \cos ^{\mathrm{k}} e\right)$; where

$\mathrm{BV}_{\text {normali }}=$ Normalized brightness values

$\mathrm{BV}_{\text {observed }}=$ Observed brightness values

$\cos i=$ Cosine of the incidence angle

$\cos e=$ Cosine of the slope angle

$k=$ Minnaert constant 


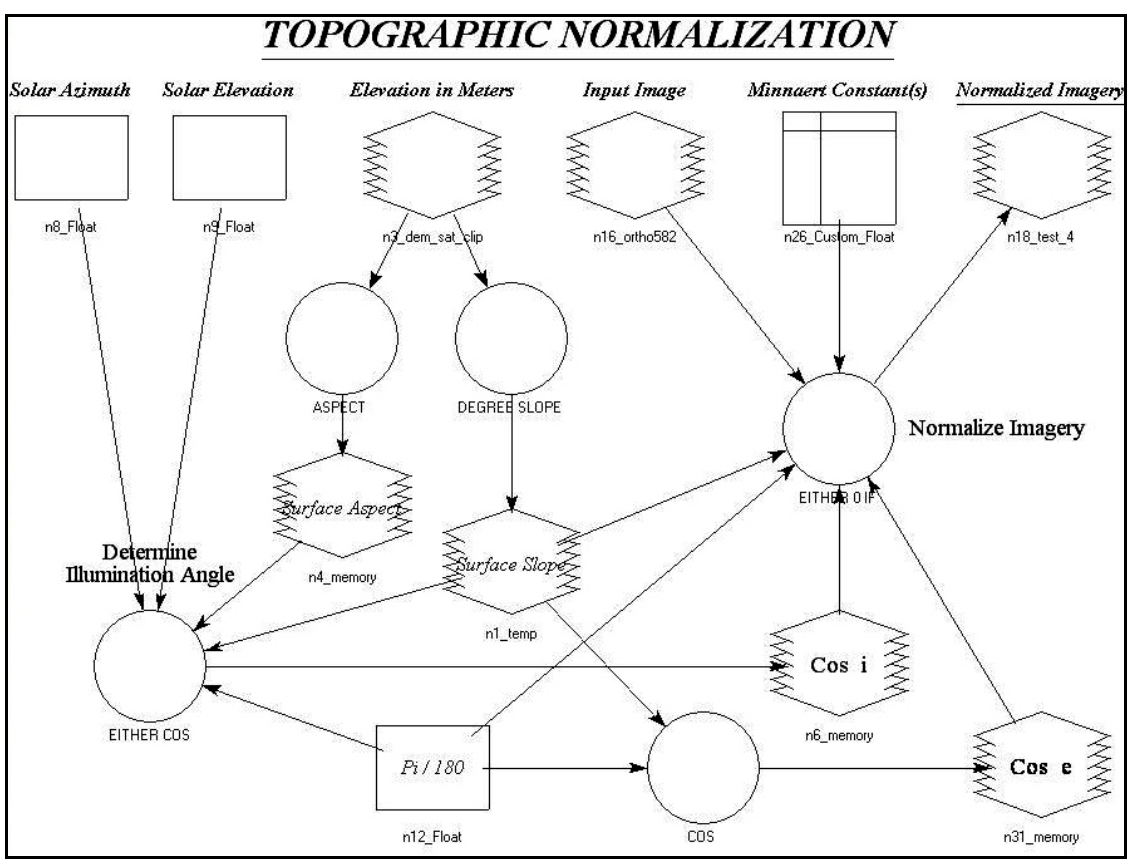

Figure 7: Non-Lambertian model included in ERDAS Imagine 9.1 to correct for topographic effects.

A Gaussian Maximum Likelihood supervised classification of the varying land cover types was performed. There are three basic steps involved in the supervised classification procedure (Lillesand et al., 2008). In the first step, the user identifies land cover types in advance through observation in the field (Keuchel et al., 2003). The user will collect various points known as 'training samples' as parameters for each land cover class of interest (Ibid). It is known as the training stage. Next, each pixel in the image is categorized into a particular land cover class that it most closely resembles. The step is known as the classification stage. Once the entire image has been categorized, the results are present in the output stage (Lillesand et al., 2008).

In this study, a parametric supervised classification method known as the Gaussian Maximum Likelihood (ML) algorithm using MultiSpec was carried out to identify a spectral signature for each set of training points (Richards \& Jia, 1999). The ML classifier evaluates the covariance and variance of each land cover category when 
classifying an unknown pixel. The algorithm thus assumes a Gaussian (normal) distribution for each category (Lillesand et al., 2008).

In my study, a total of seven different vegetation types were identified (Table 7) in accordance with the NFFL fire behavior fuel models (Table 6). From the seven different land cover types, a total of 188 training samples were collected in the field. The overall class performance was $92.3 \%$ and the Kappa statistic value was $87.2 \%$. Overall class performance, or overall accuracy, is calculated by dividing the total number of correctly classified pixels by the total number of pixels (Lillesand et al., 2008). Therefore, $92.3 \%$ of the pixels in the image of this study were classified correctly. The Kappa statistic measures the difference of actual agreement between reference data and an automated classifier and the chance agreement between the reference data and a random classifier (Lillesand et al., 2008). The kappa statistic is used to determine the percentage by which correctly identified pixels were correctly identified because of 'true' agreement or because of chance. As the true agreement approaches 1 and the chance approaches 0 , $\mathrm{k}$ will approach 1 (Lillesand et al., 2008). The kappa value of $87.2 \%$ in this study indicates that classification in this study was $87.2 \%$ better than a classification resulting from chance. The accuracy for each class, or producer's accuracy, is found in the $3^{\text {rd }}$ column of Table 7. Producer's accuracy describes the percent of area within a class that has been correctly indentified for that given class (Lillesand et al., 2008). All burnable vegetation types had producer's accuracy values equal to or above $93.6 \%$. However, agriculture and urban had producer's accuracy values of $71.3 \%$ and $81 \%$, respectively. The lower producer's accuracy values in the agriculture and urban classes can be contributed to the heterogeneity within the classes. Agricultural land may have a 
great deal of heterogeneity in spectral reflectance due to the variety of crop species present in the region. Different species such as corn and hay will have a different spectral reflectance. Moreover, different crop species may have different planting times, harvest times, and some may require irrigation while others may not (Oerke et al., 2010). Urban land also has a great deal of heterogeneity in spectral reflectance. Different buildings are constructed of different materials. As a consequence of the heterogeneity within these land-cover types, dividing them into sub-categories can yield better results (Lillesand et al., 2008). However, in this study agricultural land and urban areas are non-burnable. Further classification of these land cover types would be beyond the objective of this study. 


\begin{tabular}{|c|c|c|c|c|c|c|c|c|c|c|}
\hline \multicolumn{11}{|c|}{ TRAINING CLASS PERFORMANCE (Resubstitution Method) } \\
\hline \multicolumn{3}{|c|}{ Project } & \multirow{3}{*}{$\begin{array}{c}\text { Reference } \\
\text { Number } \\
\text { (Samples) }\end{array}$} & \multicolumn{7}{|c|}{ Number of Samples in Class } \\
\hline \multirow[b]{2}{*}{$\begin{array}{l}\text { Class } \\
\text { Name }\end{array}$} & \multirow[b]{2}{*}{$\begin{array}{l}\text { Class } \\
\text { No. }\end{array}$} & \multirow[b]{2}{*}{$\begin{array}{c}\text { Accuracy } \\
(\%)\end{array}$} & & 1 & 2 & 3 & 4 & 5 & 6 & 7 \\
\hline & & & & $\begin{array}{c}\text { Mod. } \\
\text { load } \\
\text { dry } \\
\text { shrub }\end{array}$ & Ag. & $\begin{array}{l}\text { Bare } \\
\text { ground }\end{array}$ & $\begin{array}{l}\text { Low load } \\
\text { dry shrub }\end{array}$ & $\begin{array}{l}\text { High } \\
\text { load dry } \\
\text { shrub }\end{array}$ & $\begin{array}{c}\text { Very } \\
\text { high load } \\
\text { dry shrub }\end{array}$ & Urban \\
\hline $\begin{array}{c}\text { Mod. load } \\
\text { dry } \\
\text { climate } \\
\text { shrub } \\
\text { (SH2) } \\
\end{array}$ & 1 & 93.7 & 857 & 803 & 0 & 0 & 28 & 14 & 1 & 11 \\
\hline $\begin{array}{l}\text { Agricult- } \\
\text { ure (NB3) }\end{array}$ & 2 & 71.3 & 17386 & 34 & $\begin{array}{c}124 \\
02\end{array}$ & 1086 & 789 & 0 & 0 & 3075 \\
\hline $\begin{array}{l}\text { Bare } \\
\text { ground } \\
\text { (NB9) }\end{array}$ & 3 & 96.5 & 14480 & 0 & 40 & 13979 & 0 & 0 & 0 & 461 \\
\hline $\begin{array}{c}\text { Low load } \\
\text { dry } \\
\text { climate } \\
\text { shrub } \\
\text { (SH1) }\end{array}$ & 4 & 93.6 & 3265 & 83 & 23 & 0 & 3056 & 0 & 0 & 103 \\
\hline $\begin{array}{l}\text { High load } \\
\text { dry } \\
\text { climate } \\
\text { shrub } \\
\text { (SH5) }\end{array}$ & 5 & 96.6 & 2716 & 50 & 0 & 0 & 0 & 2623 & 38 & 5 \\
\hline $\begin{array}{l}\text { Very high } \\
\text { load dry } \\
\text { climate }\end{array}$ & 6 & 97.4 & 61982 & 16 & 3 & 0 & 0 & 1317 & 60341 & 305 \\
\hline
\end{tabular}




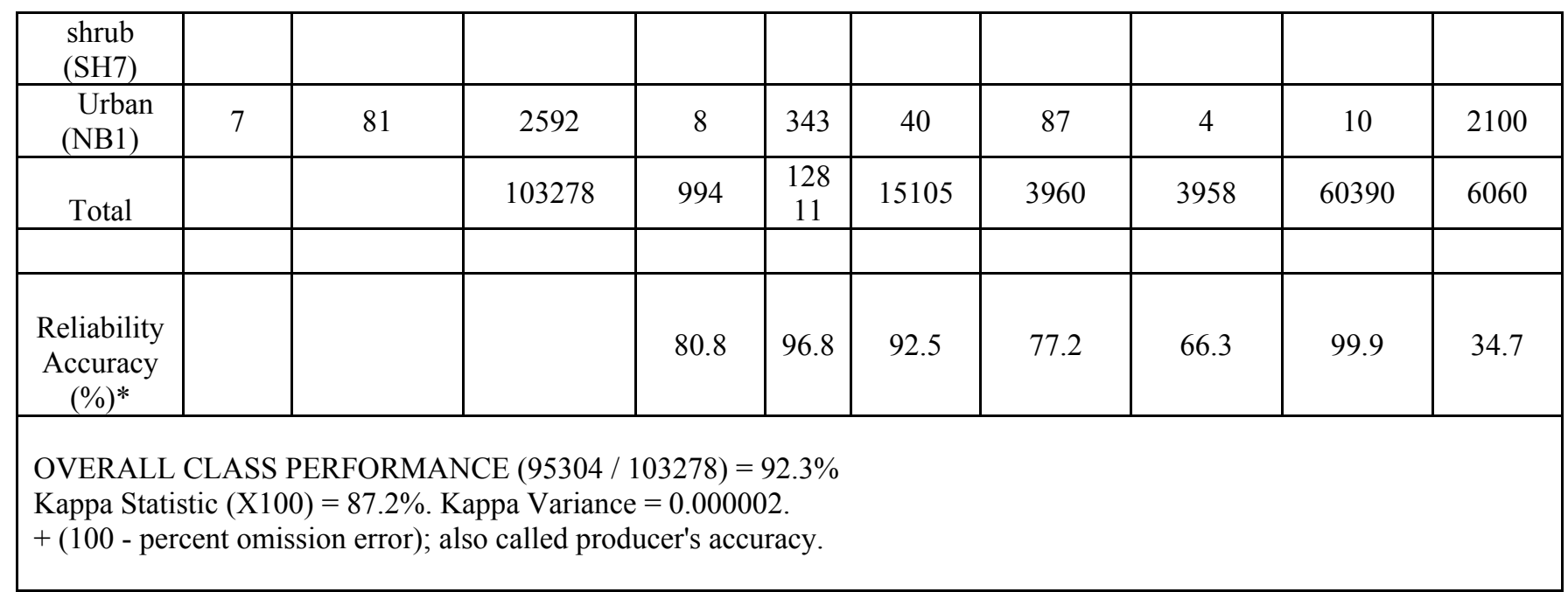

Table 7: Results of Gaussian Maximum Likelihood supervised classification. 


\subsubsection{Canopy Cover}

The default categories are: $1: 1-20 \%, 2: 21-50 \%, 3: 51-80 \%$, and $4: 81-100 \%$ (Finney, 1998). In the present study, the default category $1(1-20 \%)$ was used to classify all 7 fuel-model types. Canopy cover data can be generated through remote sensing sources similar to those used to determine the fuel model. However, a great deal of research suggests that throughout the various vegetation types of the Chihuahua desert canopy cover is consistently between $0-20$ percent.

A study by Warren et al. (1996) found honey mesquite (Prosopis glandulosa) and creosote bush (Larrea tridentata) dominated ecosystems within the Chihuahua desert to have between 9\%-16\% canopy cover. Similarly, a study by Molinar et al. (2002) found canopy cover values in the Chihuahuan Desert Rangeland Research Center to be consistently between $0 \%$ and $10 \%$. However, some extreme data values were as high as $20 \%$ canopy cover (Ibid). Other studies conducted in the Chihuahua desert have found very similar values (Khumalo et al., 2008; Ludwig et al., 2000).

\subsubsection{Meteorological Data}

Meteorological data were gathered from a live stream provided by the Secretaría de medio ambiente y recursos naturales (SEMARNAT). The SEMARNAT provides a live stream containing all necessary data every 10 minutes from the town of Matehuala, which lies 60 kilometers southeast of the study site, SLM.

\subsection{Methodology}

\subsubsection{Objective 1 Methodology}

The first objective of this study was to determine optimal width of current firebreaks. Current firebreaks in SLM protected area were simulated in FARSITE using 
the fire-barrier option to meet the exact specifications of each firebreak at 4 meters of width. The efficacy of each firebreak was tested by means of a fire simulation starting at 10:00 AM on the first and fifteenth day of each month and end at 11:00 PM on the sixteenth of each month for a 37-hour simulation. Weather and wind data was collected for the year 2003. The effectiveness of each firebreak was measured on the basis of its ability to completely stop the fire for the full 37-hour simulation. A 2:4 chi square test was conducted to test for any significant difference in the effectiveness of the 4 firebreaks currently located within the area of SLM.

\subsubsection{Objective 2 Methodology}

The second objective of this study is to determine which vegetation types/subecosystems within the protected area will experience the fastest rate of fire spread and which will experience the slowest rate of fire spread in the incidence of fire.

A total of 36 fire simulations were run in each of the 4 flammable vegetation types over a 6-hour time period with wind and weather data compiled from the year 2003. The fire simulations were carried out on the first, fifteenth and twenty-eighth day of each month beginning at 10:00 AM and ending at 4:00 PM for each vegetation type. Weather and wind data streams were the same for each vegetation type for each respective day. The size of each fire after 6 hours from ignition was recorded in hectares. A one-way analysis of variance (ANOVA) test was conducted to determine the statistical difference between the average sizes of fire for the four flammable vegetation types. A Bonferroni's test was executed to determine which means are significantly different. 


\subsubsection{Objective 3 Methodology}

The third objective of this study is to simulate prescribed burns to determine which month is the safest to implement prescribed burns based on seasonality.

A total of 6 fire simulations will be run for each month with wind and weather data compiled from the year 2003. Each fire simulations will be run on day 1, 15, and 28 for each month. The size of each fire after 24 hours from ignition was recorded in hectares. A 1-way ANOVA test was conducted to determine if there is significant difference in the average size of fire between each month for the year 2003. A Bonferroni's test was performed to determine which means are significantly different.

\subsubsection{Model Accuracy Evaluation}

In order to evaluate the accuracy of the FARSITE model for this study area, two fire simulations were run in conjunction with two fire scars from wildfires that occurred in SLM. Several other fires have occurred within the study area, but were poorly documented. In order to accurately assess the spread rate of wildfire, specific ignition and extinction times must be known.

On March 23, 2008 a fire ignited at approximately 10:00 AM and was extinguished at approximately 3:00 PM and burned 99.5 hectares. A fire simulation was conducted to best replicate the conditions from this fire on March 23, 2008. The simulation began at 10:00 AM and lasted until 3:00 PM on March 28. Weather and wind data from March 23, 2003 was used. The exact ignition point of the fire was unknown.

On April 12, 2011 a fire ignited at approximately 5:00 PM and was extinguished on April 13, 2011 at approximately 4:00 PM. The fire burned 286.4 hectares. A fire simulation was conducted to best replicate the conditions from this fire on April 12 and 
April 13, 2011. The simulation began at 5:00 PM on April 12 and lasted until on 4:00 PM on April 13. Weather and wind data from April 12 and April 13, 2003 was used. The exact ignition point of the fire was unknown.

\subsection{Limitations and Potential Errors}

The 10-meter resolution SPOT multispectral satellite image that was used for the supervised classification was taken on April 19th, 2008. However, the gathering of training samples in the field and supervised classification of the satellite image was carried out during the winter of 2011 and spring of 2012. Other this 4-year period, vegetation regimes could possibly change or shift (Miller \& Yool, 2002). Moreover, anthropogenic factors could disrupt or change land use. Since 2008, the Mexican Federal government has constructed a road and several agricultural fields have been extended by various ejidos. Other land use changes are possible.

Another potential inaccuracy in the supervised classification could result from anisotropic effects. Anisotropic effects are variations in spectral response, or uneven reflectance, that result from uneven surfaces (Tottrup, 2007). Although the NonLambertian Minnaert correction method was used to mitigate anisotropic effects, a single $\mathrm{K}$ value was chosen through visual inspection. Different slopes will have different impacts on the remotely sensed data. A pixel based analysis to determine the true value of $\mathrm{K}$ at various slopes would yield better results ( $\mathrm{Lu}$ et al., 2008).

A major limitation involving the standard NFFL fuel models deal with the initial objective of the NFFL fuel models. These fuel models were first programmed to exhibit fire behavior when wildfires pose the greatest control problems (Anderson, 1982). Therefore, these fuel models are customized for one season of the whole year. Fire 
characteristics resulting from NFFL fuel models might over-predict fire behavior during seasons of low fire concern. In other words, these over-predicted results will make it difficult to accurately assess the true risk of prescribed burns during seasons of low fire concern (Arroyo et al., 2008). In order to accurately assess fire hazard during seasons of low fire concern, custom fuel models would need to be designed that were based on fuel characteristics for that particular season.

In this study different vegetation types were identified and matched to the NFFL fuel models (Albini, 1976; Burgan \& Rothermel, 1984). The NFFL fuel models were designed to match ecosystems within the United States (Albini, 1976). The development of fuel models is a difficult and time consuming task, so there have been many efforts to design fuel models at wide geographic extents (Keane et al., 2001). However, fuels are complex and difficult to classify (Arroyo et al., 2008). Fuels are not spatially or temporally homogenous.

Fuel models are site specific. Each fuel model is only applicable for similar geographic locations and ecosystems. Previous studies have found when fuel-models are applied to foreign locations the results have been inaccurate (Arroyo et al., 2008). In this case of this study, NFFL fuel models designed for the Chihuahua desert in the southwestern United States, such as Arizona and Texas, were applied to the Chihuahua desert in San Luis Potosí, Mexico. Albeit, the ecosystem is the same, the geographic distance contributes to discrepancy.

FireFamilyPlus is a program that analyzes and summarizes databases of weather and fire occurrence data (Main et al., 1990). This program is able to calculate fire danger ratings, summarize fire and weather data streams, and make weather data compatible for 
input in FARSITE (Main et al., 1990). The use of FireFamilyPlus can streamline the process of weather data preparation for FARSITE users. However, FireFamilyPlus is only available for weather stations in the United States. FireFamilyPlus would simplify the process and allow for rapid and systematic preparation of weather data for fire simulations. For example, in a study conducted by Hollingsworth et al. a total of 2,000 fire simulations were conducted using FireFamilyPlus (2012). As the central limit theorem states 'the distribution of a normal population will approach a normal distribution as the sample size increases (Howell, 2010). An increase in fire simulations would increase the sample size for each population. As the sample sizes increase, the standard error of differences between the means would decrease (Howell, 2010). In this study, weather data was prepared for input in FARSITE manually. As a result, a limited number of fire simulations were run for each population.

\section{CHAPTER 4}

\section{RESULTS}

\subsection{Objective 1}

The first objective of this study was to assess the efficacy of three firebreaks located in three different communities of SLM: El Gallo, El Tepetate, and Los Encinos (Figure 8). Chi Square Analysis revealed that each firebreak stopped fire in all 24 firesimulations (Table 8 ). 
Firebreak Localities in Sierra La Mojonera Natural Protected Area Map created by John Brakeall
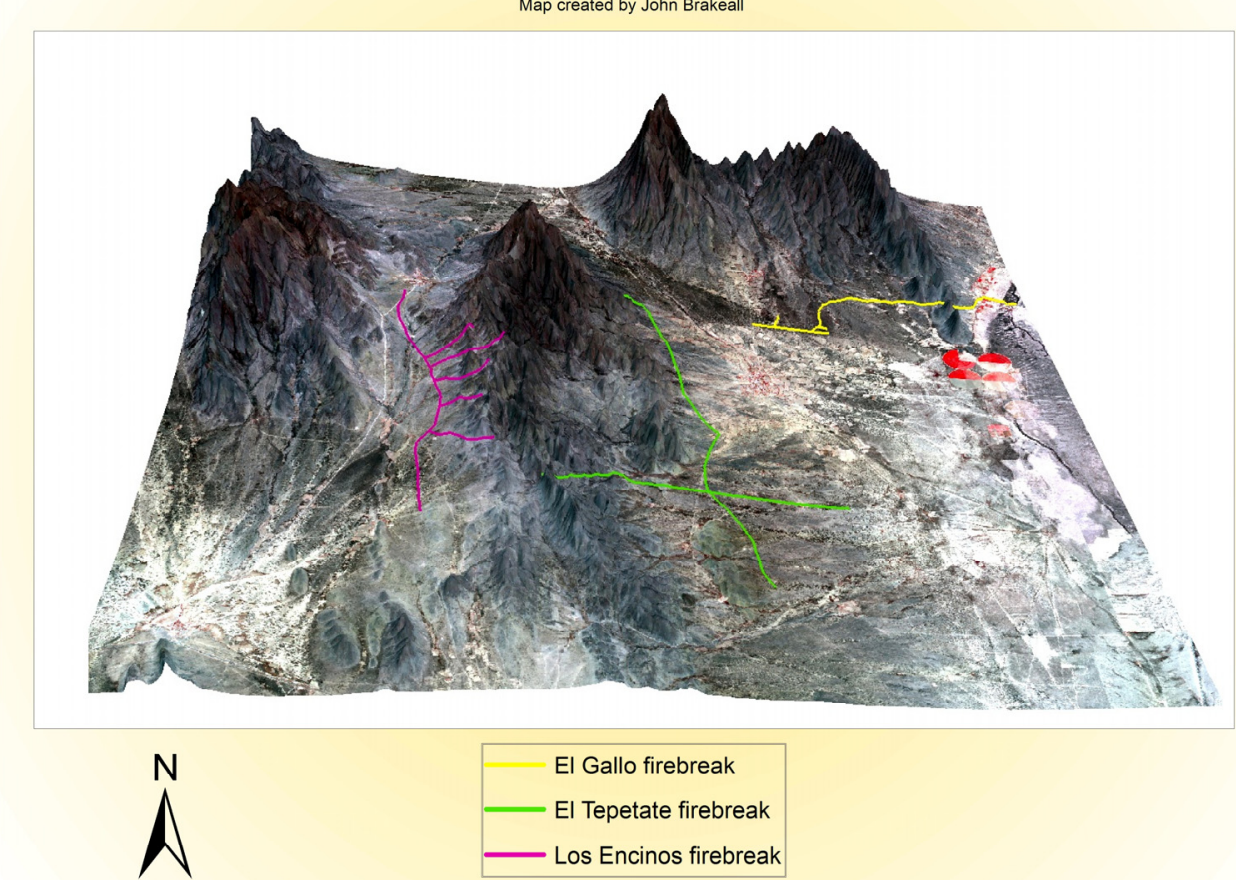

Coordinate System: WGS 1984 UTM Zone 14N

Figure 8: Map demonstrating localities of all three (3) firebreaks in SLM.

\section{Case Processing Summary}

\begin{tabular}{|c|c|c|c|c|c|c|}
\hline \multirow{2}{*}{ Firebreak } & \multicolumn{6}{|c|}{ Cases } \\
\cline { 2 - 7 } & \multicolumn{2}{|c|}{ Valid } & \multicolumn{2}{c|}{ Missing } & \multicolumn{2}{c|}{ Total } \\
\cline { 2 - 7 } & $\mathrm{N}$ & Percent & $\mathrm{N}$ & Percent & $\mathrm{N}$ & Percent \\
\hline El Gallo & 24 & $100.0 \%$ & 0 & $0.0 \%$ & 24 & $100.0 \%$ \\
El Tepetate & 24 & $100.0 \%$ & 0 & $0.0 \%$ & 24 & $100.0 \%$ \\
Los Encinos & 24 & $100.0 \%$ & 0 & $0.0 \%$ & 24 & $100.0 \%$ \\
\hline
\end{tabular}

Table 8: Summary of Chi Square Analysis for testing firebreak efficacy. All 3 firebreaks effectively stopped fire in $\% 100$ of simulations. 


\begin{tabular}{|l|c|c|c|c|}
\hline & El Gallo & EL Tepetate & Los Encinos & \multirow{2}{*}{ Total } \\
\cline { 2 - 4 } & Yes & Yes & Yes & \\
\hline 1-Jan & 1 & 1 & 1 & 3 \\
15-Jan & 1 & 1 & 1 & 3 \\
1-Feb & 1 & 1 & 1 & 3 \\
15-Feb & 1 & 1 & 1 & 3 \\
1-Mar & 1 & 1 & 1 & 3 \\
15-Mar & 1 & 1 & 1 & 3 \\
1-Apr & 1 & 1 & 1 & 3 \\
15-Apr & 1 & 1 & 1 & 3 \\
1-May & 1 & 1 & 1 & 3 \\
15-May & 1 & 1 & 1 & 3 \\
1-Jun & 1 & 1 & 1 & 3 \\
15-Jun & 1 & 1 & 1 & 3 \\
1-Jul & 1 & 1 & 1 & 3 \\
15-Jul & 1 & 1 & 1 & 3 \\
1-Aug & 1 & 1 & 1 & 3 \\
15-Aug & 1 & 1 & 1 & 3 \\
1-Sep & 1 & 1 & 1 & 3 \\
15-Sep & 1 & 1 & 1 & 3 \\
1-Oct & 1 & 1 & 1 & 3 \\
15-Oct & 1 & 1 & 1 & 3 \\
1-Nov & 1 & 1 & 1 & 3 \\
15-Nov & 1 & 1 & 1 & 3 \\
1-Dec & 1 & 1 & 1 & 3 \\
15-Dec & 1 & 1 & 1 & 3 \\
\hline Total & 24 & 1 & 1 & 3 \\
\hline
\end{tabular}

Table 9: Results of Chi Square Analysis for all three firebreaks.

The results suggest that all three firebreaks are sufficient enough to stop fire in all 12 months of the year. The average size of burnt area after the 23-hour fire simulations for El Gallo was 124.6 hectares. The average size of burnt area after the 23-hour fire simulations for El Tepetate was 82.5 hectares. The average size of burnt area after the 23 hour fire simulations for Los Encinos was 1.5 hectares. 


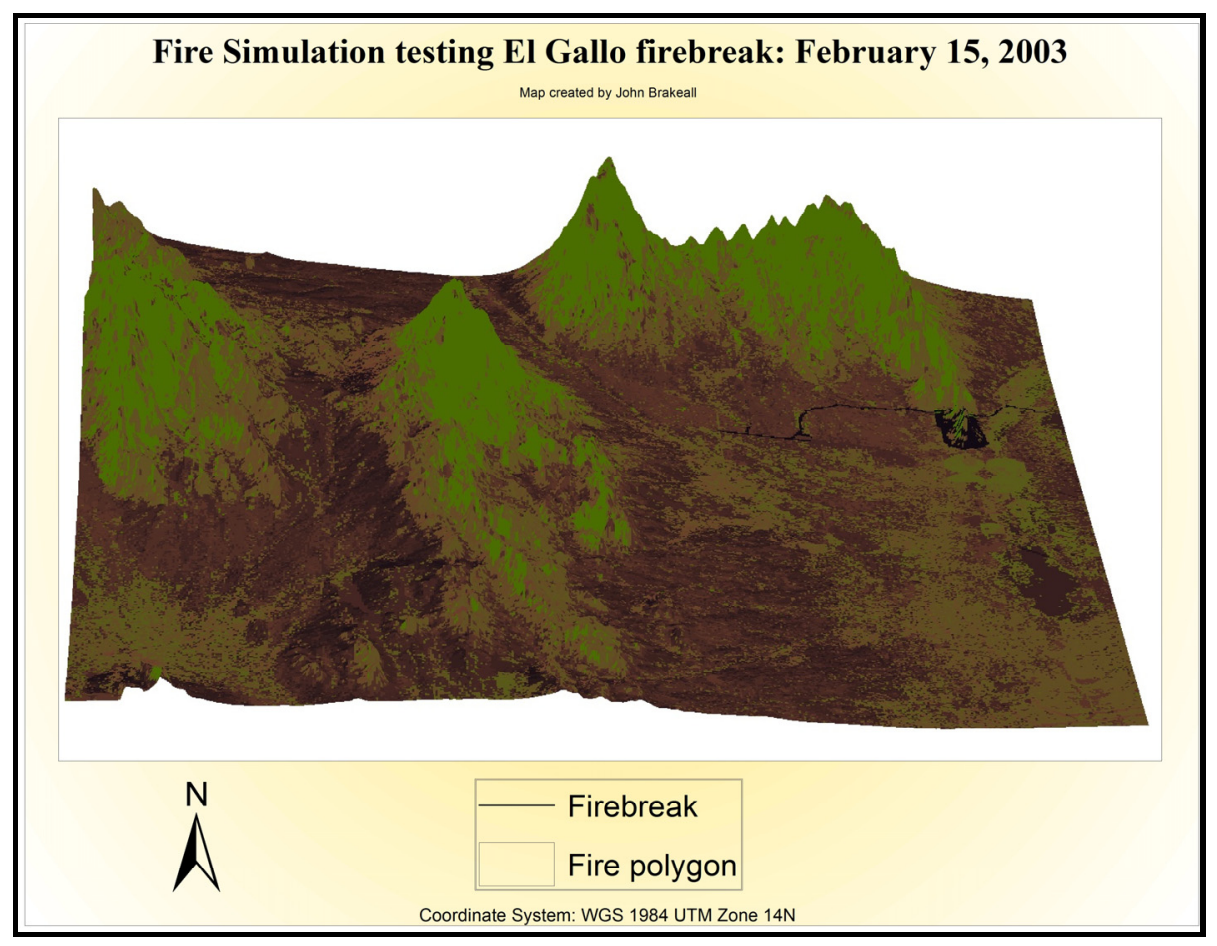

Figure 9: Map demonstrating the successful cessation of a fire simulation by El Gallo firebreak for February 15, 2003.

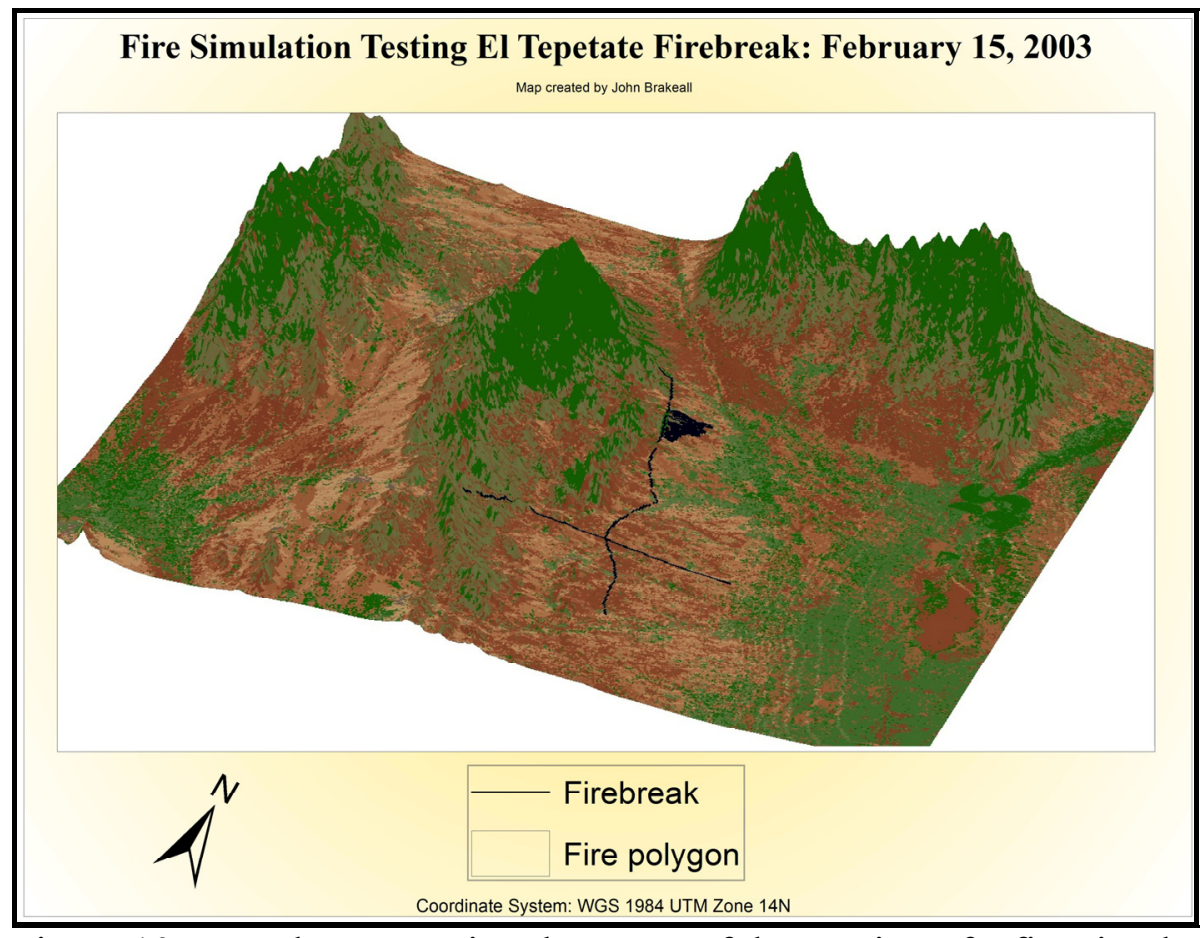

Figure 10: Map demonstrating the successful cessation of a fire simulation by El Tepetate firebreak for February 15, 2003. 


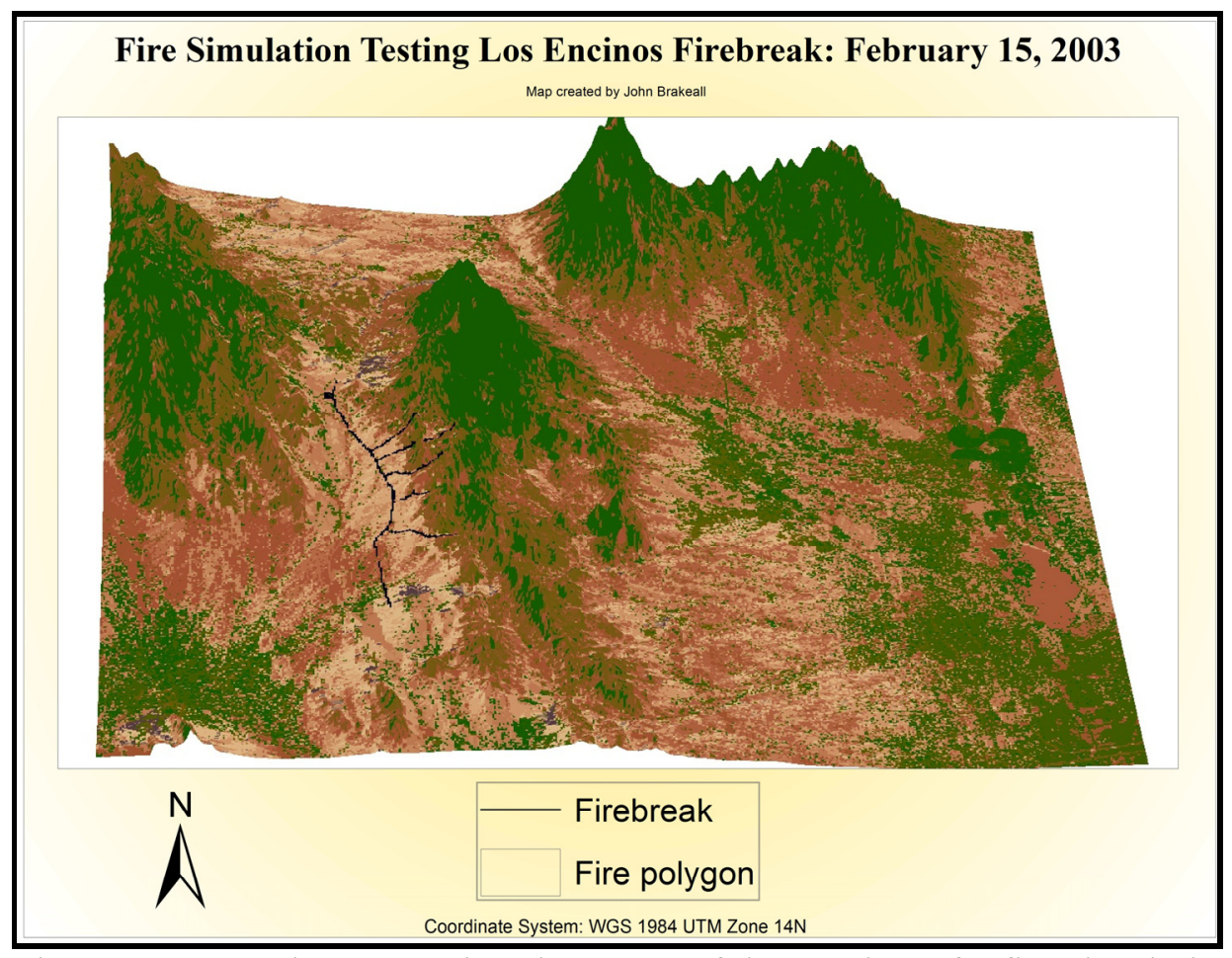

Figure 11: Map demonstrating the successful cessation of a fire simulation by Los Encinos firebreak for February 15, 2003.

\subsection{Objective 2}

The second objective of this study was to assess the rate of fire spread across the four flammable vegetation types: Very high load dry climate shrub/SH7, High load dry climate shrub/SH5, Moderate load dry climate shrub/SH2, and Low load dry climate shrub/SH1. Table 10 shows the minimum, maximum, mean, and standard deviation of area burnt in fire simulations between the four vegetation types.

Descriptive Statistics

\begin{tabular}{|c|c|c|c|c|c|}
\hline $\begin{array}{c}\text { Vegetation type/ } \\
\text { Fuel Model }\end{array}$ & $\mathrm{N}$ & $\begin{array}{c}\text { Minimum ha } \\
\text { burnt }\end{array}$ & $\begin{array}{c}\text { Maximum } \\
\text { ha burnt }\end{array}$ & $\begin{array}{c}\text { Mean ha } \\
\text { burnt }\end{array}$ & $\begin{array}{c}\text { Standard } \\
\text { Deviation }\end{array}$ \\
\hline SH7 & 48 & 14.80 & 212.80 & 96.7431 & 55.59832 \\
SH5 & 48 & 7.1 & 497.8 & 145.896 & 122.4364 \\
SH2 & 48 & 0.0 & 2.1 & 0.488 & 0.5927 \\
SH1 & 48 & 0.0 & 0.4 & 0.113 & 0.1044 \\
Valid N & 48 & & & & \\
(listwise) & & & & & \\
\hline
\end{tabular}

Table 10: Descriptive statistics generated from one-way ANOVA test. 
A one-way repeated measures ANOVA was conducted to compare the amount of area burnt during a 6-hour simulation across four vegetation types (Table 11). The conditions included vegetation type $\mathrm{SH} 7, \mathrm{SH} 5, \mathrm{SH}$, and $\mathrm{SH} 1$. There was a significant effect for the type of vegetation class burnt, Wilks' Lambda $=58.75, \mathrm{~F}(3,141)=71.69$, p $<.05)$

Multivariate Tests

\begin{tabular}{|c|c|c|c|c|c|c|c|}
\hline \multicolumn{2}{|l|}{ Effect } & Value & $\mathrm{F}$ & $\begin{array}{c}\text { Hypothesis } \\
\text { df }\end{array}$ & $\begin{array}{l}\text { Error } \\
\text { df }\end{array}$ & Sig. & $\begin{array}{c}\text { Partial } \\
\text { Eta } \\
\text { Squared }\end{array}$ \\
\hline \multirow{5}{*}{ Condition } & Pillai's Trace & .797 & 58.750 & 3.000 & 45.00 & .000 & .797 \\
\hline & Wilks' Lambda & .203 & 58.750 & 3.000 & 45.00 & .000 & .797 \\
\hline & Hotelling's & 3.917 & 58.750 & 3.000 & 45.00 & .000 & .797 \\
\hline & Trace & & & & & & \\
\hline & $\begin{array}{l}\text { Roy's Largest } \\
\text { Root }\end{array}$ & 3.917 & 58.750 & 3.000 & 45.00 & .000 & .797 \\
\hline
\end{tabular}

Table 11: Multivariate test that conclude significant differences between mean size of fire burned between all 4 vegetation types $(\mathrm{p}<.05)$.

Tests of Within-Subjects Effects

\begin{tabular}{|c|c|c|c|c|c|c|c|}
\hline \multicolumn{2}{|c|}{ Source } & $\begin{array}{l}\text { Type III } \\
\text { Sum of } \\
\text { Squares }\end{array}$ & df & $\begin{array}{l}\text { Mean } \\
\text { Square }\end{array}$ & $\mathrm{F}$ & Sig. & $\begin{array}{c}\text { Partial } \\
\text { Eta } \\
\text { Squared }\end{array}$ \\
\hline \multirow{3}{*}{ Condition } & $\begin{array}{l}\text { Sphericity } \\
\text { Assumed }\end{array}$ & 760981.393 & 3 & $\begin{array}{c}253660 \\
464\end{array}$ & 71.686 & .000 & 0.604 \\
\hline & $\begin{array}{l}\text { Greenhouse- } \\
\text { Geisser }\end{array}$ & 760981.393 & 1.127 & $\begin{array}{c}675401 \\
.645\end{array}$ & 71.686 & .000 & 0.604 \\
\hline & Huynh-Feldt & 760981.393 & 1.135 & $\begin{array}{c}670263 \\
.925\end{array}$ & 71.686 & .000 & 0.604 \\
\hline \multirow{5}{*}{$\begin{array}{c}\text { Error } \\
\text { (Condition) }\end{array}$} & Lower-bound & 760981.393 & 1.000 & $\begin{array}{c}760981 \\
393\end{array}$ & \multirow[t]{5}{*}{71.686} & \multirow[t]{5}{*}{.000} & \multirow[t]{5}{*}{0.604} \\
\hline & $\begin{array}{l}\text { Sphericity } \\
\text { Assumed }\end{array}$ & 498930.457 & 141 & $\begin{array}{c}3538.5 \\
14\end{array}$ & & & \\
\hline & $\begin{array}{l}\text { Greenhouse- } \\
\text { Geisser }\end{array}$ & 498930.457 & 52.955 & $\begin{array}{c}9421.7 \\
21\end{array}$ & & & \\
\hline & Huynh-Feldt & 498930.457 & 53.361 & $\begin{array}{c}9350.0 \\
51\end{array}$ & & & \\
\hline & Lower-bound & 498930.457 & 47.000 & $\begin{array}{c}10615 . \\
542\end{array}$ & & & \\
\hline
\end{tabular}

Table 12: Tests of Within-Subjects Effects showing degrees of freedom $(3,141)$ and $F$ test $(F=71.686)$ showing significant difference between vegetation types $(p<.05)$. 
A Bonferroni $t$ test was run to determine which means are significantly different (Table 13). All of the means were significantly different across the various vegetation types: $\mathrm{SH} 7$ vegetation type $(M=96.74, \mathrm{SD}=55.60), \mathrm{SH} 5$ vegetation type $(M=145.90$, $\mathrm{SD}=122.436), \mathrm{SH} 2$ vegetation type $(\mathrm{M}=0.488, \mathrm{SD}=0.5927), \mathrm{SH} 1$ vegetation type $(\mathrm{M}=$ 0.113, $\mathrm{SD}=0.1044)$. Follow-up pairwise comparisons using Bonferroni adjustment indicate that all conditions are significantly different from each other (Table 13).

\section{Pairwise Comparisons}

Measure: Vegetation types

\begin{tabular}{|c|c|c|c|c|c|c|}
\hline \multirow[t]{2}{*}{$\begin{array}{c}\text { (I) } \\
\text { Condition }\end{array}$} & \multirow[t]{2}{*}{$\begin{array}{c}(\mathrm{J}) \\
\text { Condition }\end{array}$} & \multirow[t]{2}{*}{$\begin{array}{c}\text { Mean } \\
\text { Difference (I-J) }\end{array}$} & \multirow[t]{2}{*}{$\begin{array}{l}\text { Std. } \\
\text { Error }\end{array}$} & \multirow[t]{2}{*}{ Sig. ${ }^{b}$} & \multicolumn{2}{|c|}{$\begin{array}{l}95 \% \text { Confidence Interval } \\
\text { for Difference }\end{array}$} \\
\hline & & & & & $\begin{array}{l}\text { Lower } \\
\text { Bound }\end{array}$ & $\begin{array}{l}\text { Upper } \\
\text { Bound }\end{array}$ \\
\hline \multirow{4}{*}{ SH7 } & SH5 & $-49.153^{*}$ & 11.631 & .001 & -81.192 & -17.113 \\
\hline & $\mathrm{SH} 2$ & $96.256^{*}$ & 7.958 & .000 & 74.336 & 118.176 \\
\hline & SH1 & $96.631^{*}$ & 8.013 & .000 & 74.558 & 118.703 \\
\hline & $\mathrm{SH} 7$ & $49.153^{*}$ & 11.631 & .001 & 17.113 & 81.192 \\
\hline \multirow[t]{3}{*}{ SH5 } & $\mathrm{SH} 2$ & $145.408^{*}$ & 17.606 & .000 & 96.913 & 193.904 \\
\hline & SH1 & $145.783^{*}$ & 17.659 & .000 & 97.141 & 194.426 \\
\hline & SH7 & $-96.256^{*}$ & 7.958 & .000 & -118.176 & -74.336 \\
\hline \multirow[t]{3}{*}{$\mathrm{SH} 2$} & SH5 & $-145.408^{*}$ & 17.606 & .000 & -193.904 & -96.913 \\
\hline & SH1 & $0.375^{*}$ & 0.076 & .000 & 0.166 & 0.584 \\
\hline & SH7 & $-96.631^{*}$ & 8.013 & .000 & -118.703 & -74.558 \\
\hline \multirow[t]{2}{*}{ SH1 } & SH5 & $-145.783^{*}$ & 17.659 & .000 & -194.426 & -97.141 \\
\hline & $\mathrm{SH} 2$ & $-0.375^{*}$ & 0.076 & .000 & -0.584 & -0.166 \\
\hline
\end{tabular}

Table 13: Pairwise comparisons test based on estimated marginal means. " signifies the mean difference is significant at the .05 level. ${ }^{\mathrm{b}}$ is adjustment for multiple comparisons: Bonferroni. 


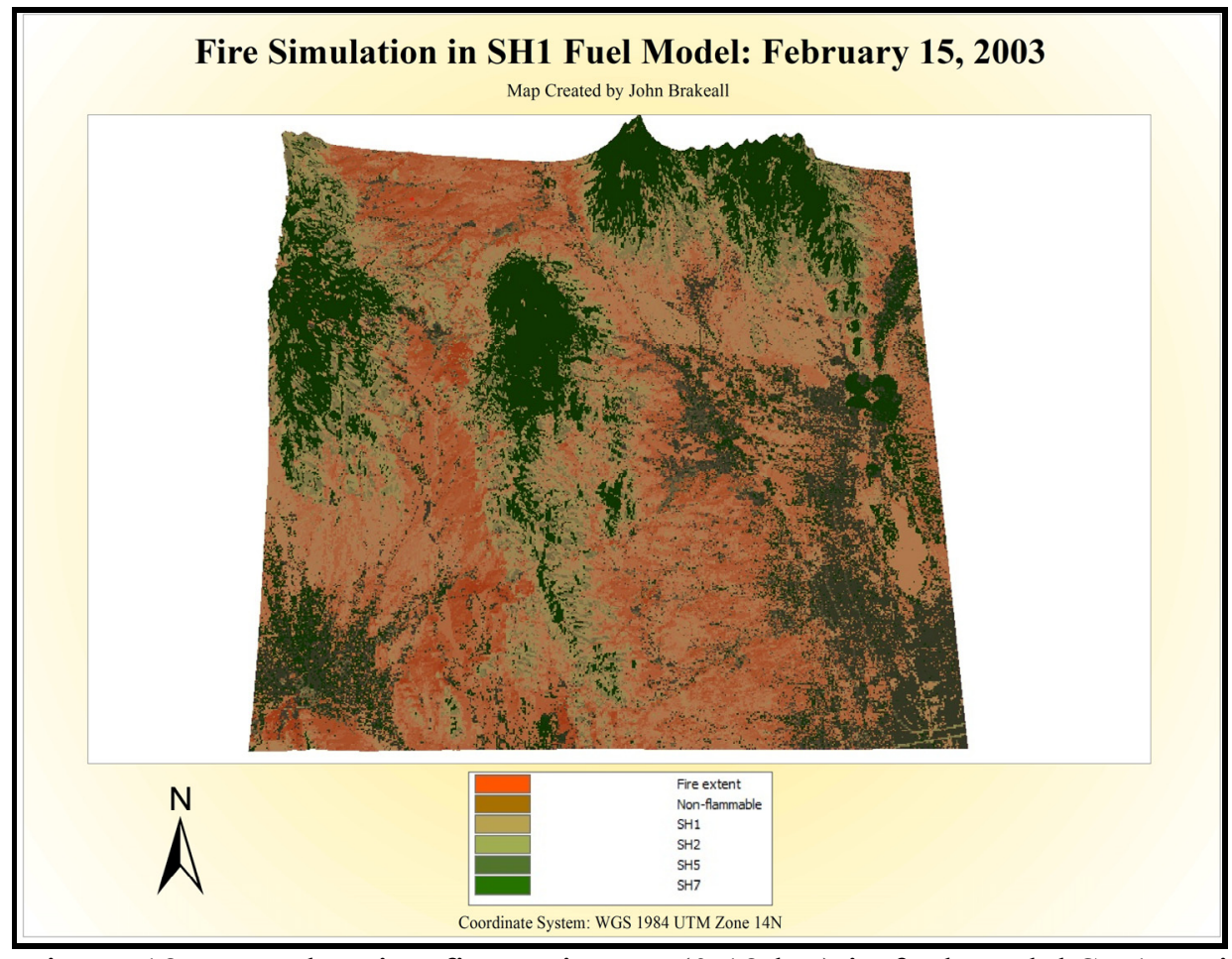

Figure 12: Map showing fire perimeter (0.12 ha.) in fuel model SH1 at site 2.

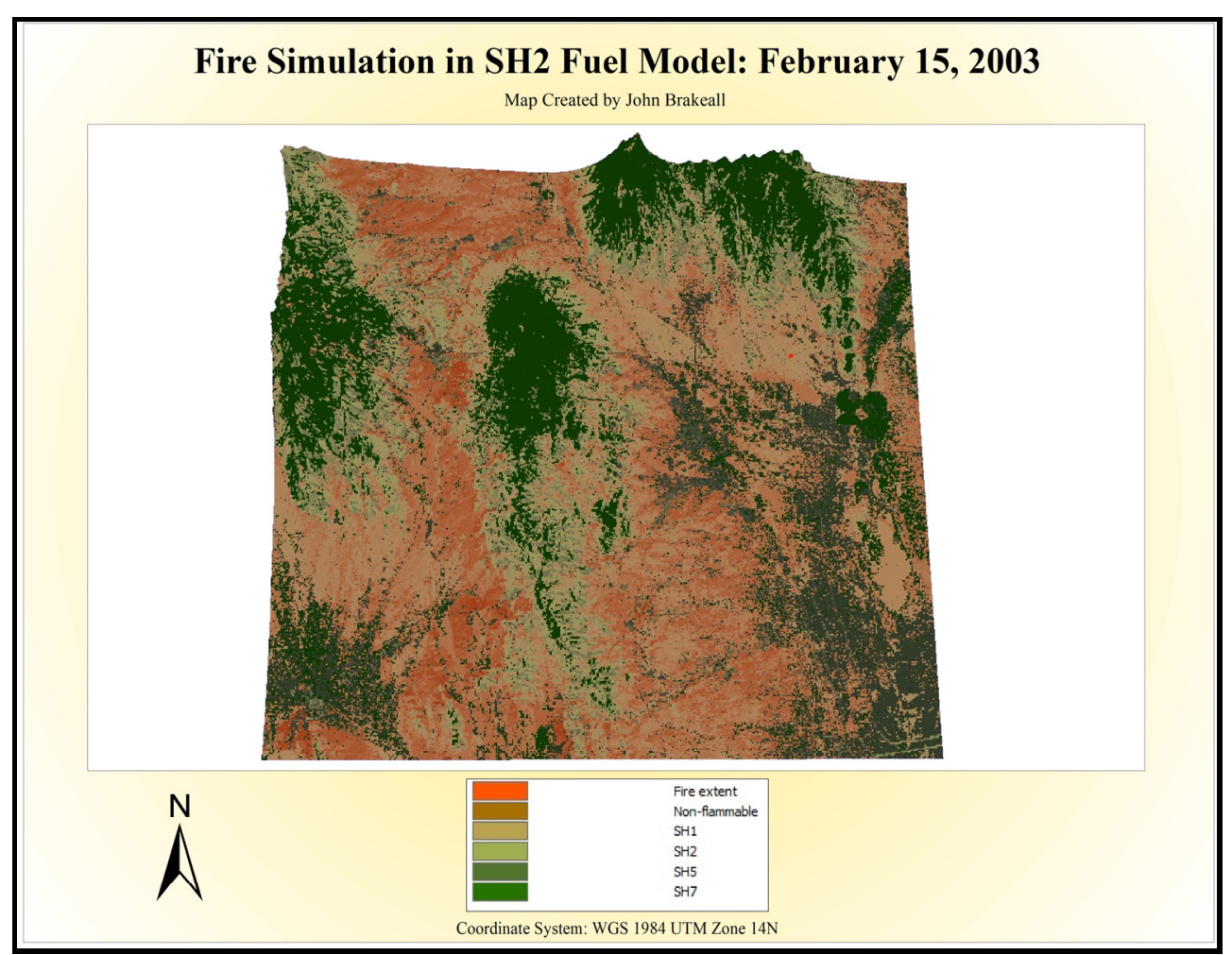

Figure 13: Map showing fire perimeter (0.43 ha.) in fuel model SH2 at site 2. 


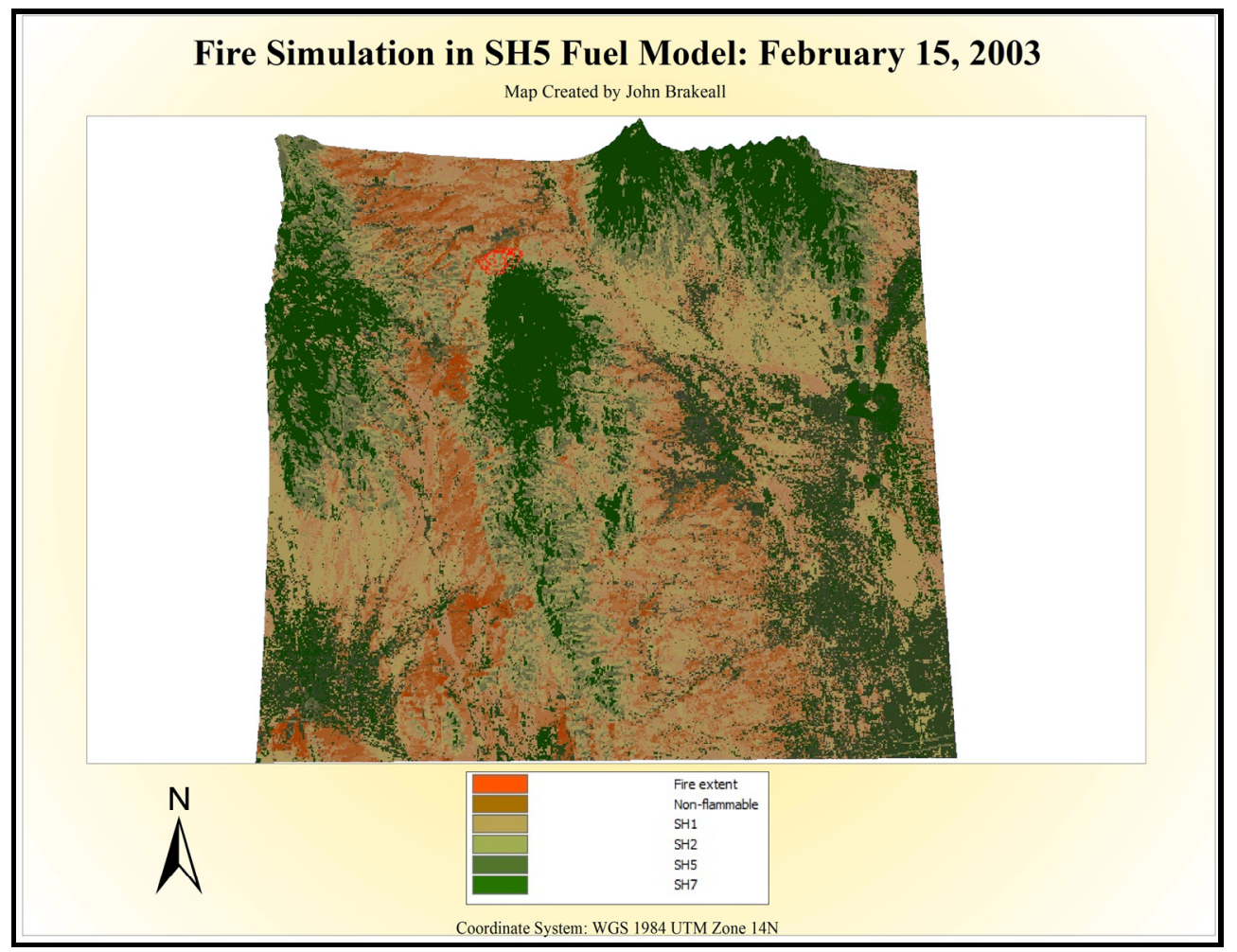

Figure 14: Map showing fire perimeter (160.33 ha.) in fuel model SH5 at site 2. 


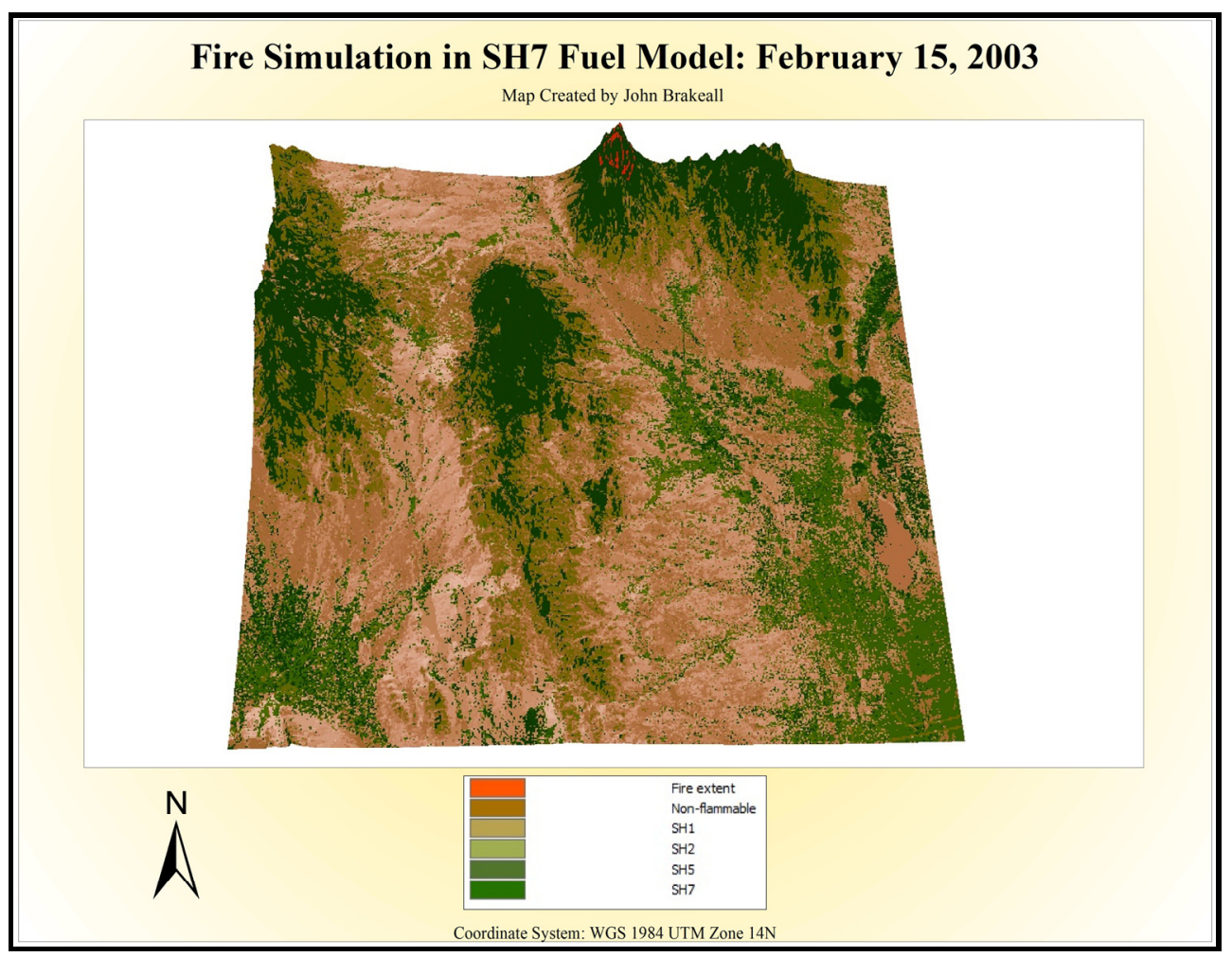

Figure 15: Map showing fire perimeter (145.102 ha.) in fuel model SH7 at site 2.

Biomass did not have a direct relationship on fire vulnerability as hypothesized. SH7 vegetation type has the largest amount of biomass with 6.9 tons of fine fuel per hectare, but experienced significantly slower fire burn rates than the SH5 vegetation type, which contains 6.5 tons of fine fuel per hectare $(p<.05)$. SH1 and SH2 vegetation types experienced an average burn size of less than 1 hectare after a 6-hour simulation with 0.113 and 0.488 hectares burnt, respectively.

Although there is significant difference in the average area burnt between all vegetation types, it seems as though the $\mathrm{SH} 1$ and $\mathrm{SH} 2$ vegetation types have low threat to fire. Meanwhile, the SH5 and SH7 vegetation types seem considerably more vulnerable to fire. 


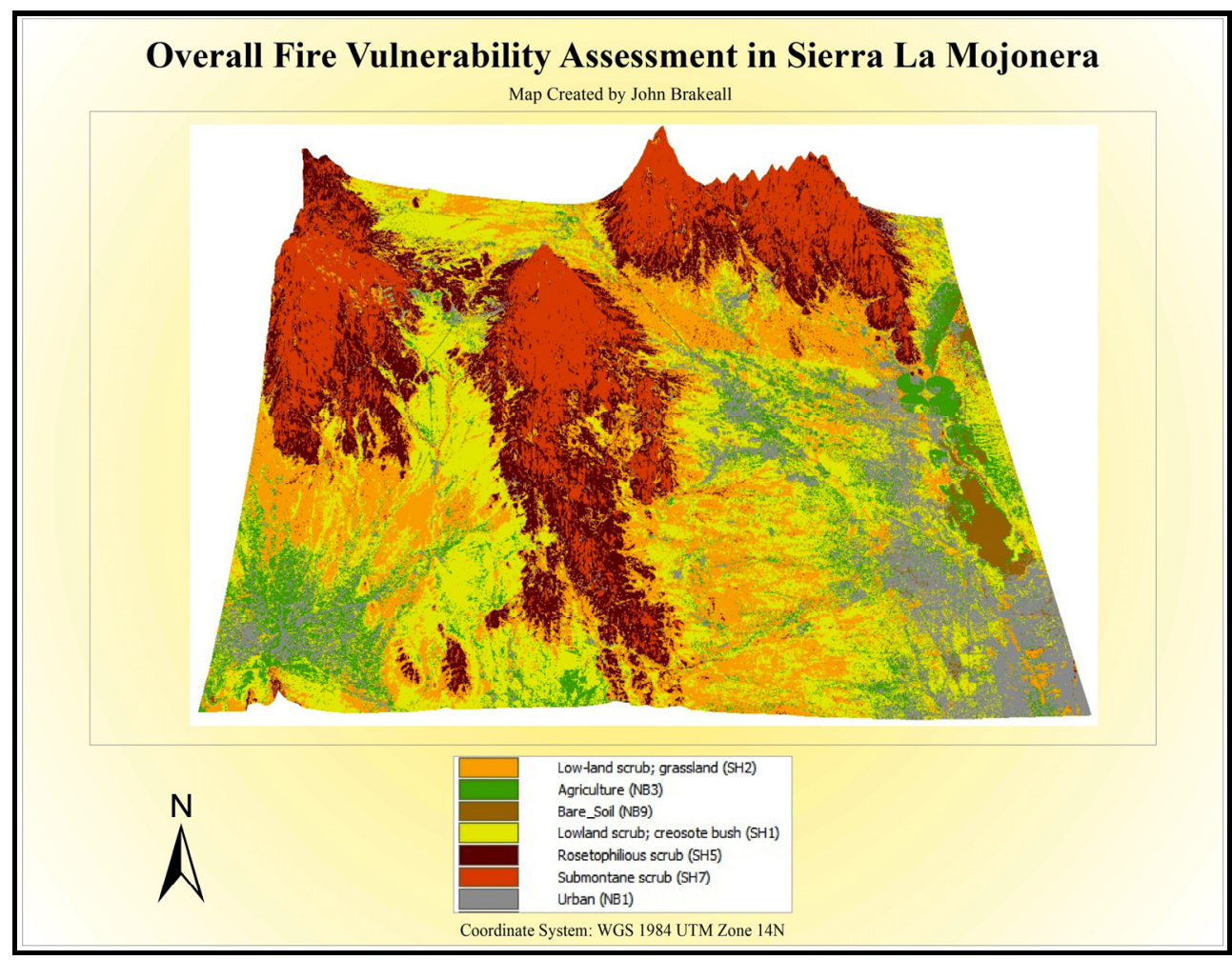

Figure 16: Overall fire vulnerability assessment in SLM based on vegetation type.

\subsection{Objective 3}

The third objective of this study was to assess the rate of fire spread across the twelve different months of the year: January February, March, April, May, June, July, August, September, October, November, and December. Table 14 shows the minimum, maximum, mean, and standard deviation values between the twelve months. The month of March experienced the fastest average rate of fire spread (117.250 ha.) during a 6-hour simulation while September experienced the slowest rate of fire spread (10.846 ha.) during a 6-hour simulation. 


\section{Descriptive Statistics}

\begin{tabular}{|c|c|c|c|c|c|}
\hline & $\mathrm{N}$ & Minimum & Maximum & Mean & Std. Deviation \\
\hline January & 24 & .1 & 290.20 & 82.1696 & 92.90761 \\
February & 24 & .1 & 497.8 & 107.746 & 134.0171 \\
March & 24 & .2 & 383.5 & 117.250 & 135.5641 \\
April & 24 & .0 & 384.5 & 82.367 & 114.8608 \\
May & 24 & .0 & 103.4 & 36.046 & 39.9752 \\
June & 24 & .0 & 87.9 & 25.346 & 29.0242 \\
July & 24 & .0 & 64.1 & 21.396 & 22.5281 \\
August & 24 & .0 & 79.2 & 24.200 & 27.4529 \\
September & 24 & .0 & 57.5 & 10.846 & 15.3560 \\
October & 24 & 0 & 127 & 34.08 & 45.971 \\
November & 24 & .1 & 270.7 & 82.833 & 94.0886 \\
December & 24 & .1 & 357.1 & 105.992 & 122.2301 \\
Valid N & 24 & & & & \\
(listwise) & & & & & \\
\hline
\end{tabular}

Table 14: Descriptive statistics generated from one-way ANOVA test.

A one-way repeated measures ANOVA was conducted to compare the amount of area burnt during a 6-hour simulation across the twelve months of the year (Table 15).

There was a significant effect for the type of vegetation class burnt, Wilks' Lambda = $1.189, \mathrm{~F}(11,253)=11.084, \mathrm{p}<.05)$

Multivariate Tests

\begin{tabular}{|r|c|c|c|c|c|c|}
\hline Effect & Value & $\mathrm{F}$ & $\begin{array}{c}\text { Hypothesis } \\
\mathrm{df}\end{array}$ & Error df & Sig. & $\begin{array}{c}\text { Partial } \\
\text { Eta } \\
\text { Squared }\end{array}$ \\
\hline $\begin{array}{c}\text { Pillai's } \\
\text { Trace } \\
\text { Wilks' } \\
\text { Lambda }\end{array}$ & .502 & $1.189^{\mathrm{b}}$ & 11.000 & 13.000 & .378 & .502 \\
Month $\begin{array}{c}\text { Hotelling' } \\
\text { s Trace } \\
\text { Roy's } \\
\text { Largest } \\
\text { Root }\end{array}$ & 1.006 & $1.189^{\mathrm{b}}$ & 11.000 & 13.000 & .378 & .502 \\
\hline
\end{tabular}

Table 15: Multivariate test that conclude significant difference between mean size of fire burned between all 4 vegetation types $(\mathrm{p}<.05)$. 
Tests of Within-Subjects Effects

Measure: Month

\begin{tabular}{|c|c|c|c|c|c|c|c|}
\hline \multicolumn{2}{|c|}{ Source } & $\begin{array}{c}\text { Type III Sum } \\
\text { of Squares }\end{array}$ & $\mathrm{df}$ & $\begin{array}{l}\text { Mean } \\
\text { Square }\end{array}$ & $\mathrm{F}$ & Sig. & $\begin{array}{l}\text { Partial } \\
\text { Eta } \\
\text { Squared }\end{array}$ \\
\hline \multirow{3}{*}{ Month } & $\begin{array}{l}\text { Sphericity } \\
\text { Assumed }\end{array}$ & 403474.75 & 11 & 36679.52 & 11.084 & .000 & .325 \\
\hline & $\begin{array}{l}\text { Greenhouse- } \\
\text { Geisser }\end{array}$ & 403474.75 & 2.162 & $\begin{array}{c}186626.3 \\
9\end{array}$ & 11.084 & .000 & .325 \\
\hline & Huynh-Feldt & 403474.75 & 2.394 & $\begin{array}{c}168535.1 \\
4\end{array}$ & 11.084 & .000 & .325 \\
\hline \multirow{5}{*}{$\begin{array}{c}\text { Error } \\
\text { (Month) }\end{array}$} & $\begin{array}{l}\text { Lower- } \\
\text { bound }\end{array}$ & 403474.75 & 1.000 & $\begin{array}{c}403474.7 \\
5\end{array}$ & \multirow[t]{5}{*}{11.084} & \multirow[t]{5}{*}{.003} & \multirow[t]{5}{*}{.325} \\
\hline & $\begin{array}{l}\text { Sphericity } \\
\text { Assumed }\end{array}$ & 837210.00 & 253 & 3309.13 & & & \\
\hline & $\begin{array}{l}\text { Greenhouse- } \\
\text { Geisser }\end{array}$ & 837210.00 & 49.725 & 16836.94 & & & \\
\hline & Huynh-Feldt & 837210.00 & 55.062 & 15204.80 & & & \\
\hline & $\begin{array}{c}\text { Lower- } \\
\text { bound }\end{array}$ & 837210.00 & 23.000 & 36400.44 & & & \\
\hline
\end{tabular}

Table 16: Tests of Within-Subjects Effects showing ( $\mathrm{df}=11,253 ; \mathrm{F}=11.084)$ significant difference between vegetation types $(\mathrm{p}<.05)$.

A Bonferroni $t$ test was run to determine which means are different (Table 16).

There was a significant effect for the type of vegetation class burnt, Wilks' Lambda = $58.75, \mathrm{~F}(3,141)=71.69, \mathrm{p}<.05$. Follow-up pairwise comparisons using Bonferroni adjustment indicate that all conditions are significantly different from each other.

The findings from this study suggest that there is no significant difference in mean area burnt between many of the months. However, the results show that there is significant difference between January and June, July, August, September. There is significant difference between March and June, July August, September. There is significant difference between May and September, December. There is significant difference between June and November. There is significant difference between July and November, December. There is significant difference between August and November. 
There is significant difference between September and November, December (Table 17).

\begin{tabular}{|c|c|c|c|c|c|c|}
\hline \multicolumn{7}{|c|}{ Pairwise Comparisons } \\
\hline \multicolumn{7}{|c|}{ Measure: Month } \\
\hline \multirow[t]{2}{*}{$\begin{array}{c}\text { (I) } \\
\text { Month }\end{array}$} & \multirow[t]{2}{*}{$\begin{array}{c}(\mathrm{J}) \\
\text { Month }\end{array}$} & \multirow{2}{*}{$\begin{array}{c}\text { Mean } \\
\text { Difference } \\
(\mathrm{I}-\mathrm{J})\end{array}$} & \multirow[t]{2}{*}{ Std. Error } & \multirow[t]{2}{*}{ Sig. $^{b}$} & \multicolumn{2}{|c|}{$\begin{array}{l}95 \% \text { Confidence Interval } \\
\text { for Difference }\end{array}$} \\
\hline & & & & & $\begin{array}{l}\text { Lower } \\
\text { Bound } \\
\end{array}$ & $\begin{array}{l}\text { Upper } \\
\text { Bound } \\
\end{array}$ \\
\hline \multirow{16}{*}{1} & 2 & -25.576 & 15.491 & 1 & -85.679 & 34.526 \\
\hline & 3 & -35.08 & 11.896 & 0.475 & -81.238 & 11.077 \\
\hline & 4 & -0.197 & 21.412 & 1 & -83.275 & 82.881 \\
\hline & 5 & 46.124 & 14.406 & 0.262 & -9.771 & 102.019 \\
\hline & 6 & $56.824^{*}$ & 13.645 & 0.025 & 3.882 & 109.766 \\
\hline & 7 & $60.774^{*}$ & 15.387 & 0.042 & 1.071 & 120.477 \\
\hline & 8 & $57.970^{*}$ & 14.282 & 0.032 & 2.556 & 113.383 \\
\hline & 9 & $71.324^{*}$ & 17.118 & 0.025 & 4.906 & 137.741 \\
\hline & 10 & 48.09 & 15.323 & 0.304 & -11.364 & 107.545 \\
\hline & 11 & -0.664 & 4.704 & 1 & -18.914 & 17.586 \\
\hline & 12 & -23.822 & 15.599 & 1 & -84.345 & 36.701 \\
\hline & 1 & 25.576 & 15.491 & 1 & -34.526 & 85.679 \\
\hline & 3 & -9.504 & 12.117 & 1 & -56.518 & 37.509 \\
\hline & 4 & 25.379 & 18.486 & 1 & -46.345 & 97.104 \\
\hline & 5 & 71.7 & 21.893 & 0.219 & -13.243 & 156.643 \\
\hline & 6 & 82.4 & 22.849 & 0.098 & -6.254 & 171.054 \\
\hline \multirow[t]{11}{*}{2} & 7 & 86.35 & 23.601 & 0.086 & -5.219 & 177.919 \\
\hline & 8 & 83.546 & 22.872 & 0.088 & -5.198 & 172.29 \\
\hline & 9 & 96.9 & 26.283 & 0.081 & -5.078 & 198.878 \\
\hline & 10 & 73.667 & 21.375 & 0.145 & -9.269 & 156.602 \\
\hline & 11 & 24.913 & 13.643 & 1 & -28.023 & 77.848 \\
\hline & 12 & 1.754 & 16.768 & 1 & -63.304 & 66.813 \\
\hline & 1 & 35.08 & 11.896 & 0.475 & -11.077 & 81.238 \\
\hline & 2 & 9.504 & 12.117 & 1 & -37.509 & 56.518 \\
\hline & 4 & 34.883 & 20.88 & 1 & -46.132 & 115.898 \\
\hline & 5 & 81.204 & 22.224 & 0.087 & -5.024 & 167.433 \\
\hline & 6 & $91.904^{*}$ & 22.485 & 0.03 & 4.662 & 179.146 \\
\hline \multirow[t]{6}{*}{3} & 7 & $95.854^{*}$ & 23.722 & 0.034 & 3.813 & 187.896 \\
\hline & 8 & $93.050^{*}$ & 22.822 & 0.031 & 4.502 & 181.598 \\
\hline & 9 & $106.404^{*}$ & 26.316 & 0.033 & 4.297 & 208.511 \\
\hline & 10 & 83.171 & 22.025 & 0.065 & -2.285 & 168.627 \\
\hline & 11 & 34.417 & 10.915 & 0.294 & -7.933 & 76.766 \\
\hline & 12 & 11.258 & 14.062 & 1 & -43.301 & 65.818 \\
\hline \multirow[t]{5}{*}{4} & 1 & 0.197 & 21.412 & 1 & -82.881 & 83.275 \\
\hline & 2 & -25.379 & 18.486 & 1 & -97.104 & 46.345 \\
\hline & 3 & -34.883 & 20.88 & 1 & -115.898 & 46.132 \\
\hline & 5 & 46.321 & 16.474 & 0.653 & -17.598 & 110.24 \\
\hline & 6 & 57.021 & 21.274 & 0.882 & -25.522 & 139.564 \\
\hline
\end{tabular}




\begin{tabular}{|c|c|c|c|c|c|c|}
\hline & 7 & 60.971 & 19.773 & 0.346 & -15.749 & 137.691 \\
\hline & 8 & 58.167 & 20.664 & 0.649 & -22.009 & 138.342 \\
\hline & 9 & 71.521 & 22.4 & 0.267 & -15.39 & 158.432 \\
\hline & 10 & 48.288 & 18.075 & 0.9 & -21.843 & 118.418 \\
\hline & 11 & -0.467 & 19.328 & 1 & -75.459 & 74.526 \\
\hline & 12 & -23.625 & 12.837 & 1 & -73.433 & 26.183 \\
\hline & 1 & -46.124 & 14.406 & 0.262 & -102.019 & 9.771 \\
\hline & 2 & -71.7 & 21.893 & 0.219 & -156.643 & 13.243 \\
\hline & 3 & -81.204 & 22.224 & 0.087 & -167.433 & 5.024 \\
\hline & 4 & -46.321 & 16.474 & 0.653 & -110.24 & 17.598 \\
\hline & 6 & 10.7 & 6.118 & 1 & -13.039 & 34.439 \\
\hline \multirow[t]{11}{*}{5} & 7 & 14.65 & 4.13 & 0.113 & -1.374 & 30.674 \\
\hline & 8 & 11.846 & 5.649 & 1 & -10.073 & 33.764 \\
\hline & 9 & $25.200^{*}$ & 6.439 & 0.046 & 0.216 & 50.184 \\
\hline & 10 & 1.967 & 6.889 & 1 & -24.761 & 28.695 \\
\hline & 11 & -46.788 & 14.043 & 0.191 & -101.275 & 7.7 \\
\hline & 12 & $-69.946^{*}$ & 17.598 & 0.04 & -138.226 & -1.665 \\
\hline & 1 & $-56.824^{*}$ & 13.645 & 0.025 & -109.766 & -3.882 \\
\hline & 2 & -82.4 & 22.849 & 0.098 & -171.054 & 6.254 \\
\hline & 3 & $-91.904^{*}$ & 22.485 & 0.03 & -179.146 & -4.662 \\
\hline & 4 & -57.021 & 21.274 & 0.882 & -139.564 & 25.522 \\
\hline & 5 & -10.7 & 6.118 & 1 & -34.439 & 13.039 \\
\hline \multirow[t]{11}{*}{6} & 7 & 3.95 & 3.103 & 1 & -8.091 & 15.991 \\
\hline & 8 & 1.146 & 1.287 & 1 & -3.849 & 6.141 \\
\hline & 9 & 14.5 & 4.912 & 0.472 & -4.559 & 33.559 \\
\hline & 10 & -8.733 & 6.26 & 1 & -33.02 & 15.553 \\
\hline & 11 & $-57.488^{*}$ & 14.274 & 0.035 & -112.868 & -2.107 \\
\hline & 12 & -80.646 & 21.287 & 0.063 & -163.24 & 1.948 \\
\hline & 1 & $-60.774^{*}$ & 15.387 & 0.042 & -120.477 & -1.071 \\
\hline & 2 & -86.35 & 23.601 & 0.086 & -177.919 & 5.219 \\
\hline & 3 & $-95.854^{*}$ & 23.722 & 0.034 & -187.896 & -3.813 \\
\hline & 4 & -60.971 & 19.773 & 0.346 & -137.691 & 15.749 \\
\hline & 5 & -14.65 & 4.13 & 0.113 & -30.674 & 1.374 \\
\hline \multirow[t]{6}{*}{7} & 6 & -3.95 & 3.103 & 1 & -15.991 & 8.091 \\
\hline & 8 & -2.804 & 2.473 & 1 & -12.4 & 6.792 \\
\hline & 9 & 10.55 & 3.591 & 0.488 & -3.384 & 24.484 \\
\hline & 10 & -12.683 & 6.154 & 1 & -36.56 & 11.193 \\
\hline & 11 & $-61.438^{*}$ & 15.488 & 0.04 & -121.531 & -1.344 \\
\hline & 12 & $-84.596^{*}$ & 20.829 & 0.032 & -165.413 & -3.779 \\
\hline \multirow[t]{9}{*}{8} & 1 & $-57.970^{*}$ & 14.282 & 0.032 & -113.383 & -2.556 \\
\hline & 2 & -83.546 & 22.872 & 0.088 & -172.29 & 5.198 \\
\hline & 3 & $-93.050^{*}$ & 22.822 & 0.031 & -181.598 & -4.502 \\
\hline & 4 & -58.167 & 20.664 & 0.649 & -138.342 & 22.009 \\
\hline & 5 & -11.846 & 5.649 & 1 & -33.764 & 10.073 \\
\hline & 6 & -1.146 & 1.287 & 1 & -6.141 & 3.849 \\
\hline & 7 & 2.804 & 2.473 & 1 & -6.792 & 12.4 \\
\hline & 9 & 13.354 & 4.692 & 0.603 & -4.849 & 31.557 \\
\hline & 10 & -9.879 & 5.511 & 1 & -31.261 & 11.502 \\
\hline
\end{tabular}




\begin{tabular}{|c|c|c|c|c|c|c|}
\hline & 11 & $-58.633^{*}$ & 14.818 & 0.041 & -116.125 & -1.142 \\
\hline & 12 & -81.792 & 21.302 & 0.055 & -164.441 & 0.858 \\
\hline & 1 & $-71.324^{*}$ & 17.118 & 0.025 & -137.741 & -4.906 \\
\hline & 2 & -96.9 & 26.283 & 0.081 & -198.878 & 5.078 \\
\hline & 3 & $-106.404^{*}$ & 26.316 & 0.033 & -208.511 & -4.297 \\
\hline & 4 & -71.521 & 22.4 & 0.267 & -158.432 & 15.39 \\
\hline & 5 & $-25.200^{*}$ & 6.439 & 0.046 & -50.184 & -0.216 \\
\hline \multirow[t]{11}{*}{9} & 6 & -14.5 & 4.912 & 0.472 & -33.559 & 4.559 \\
\hline & 7 & -10.55 & 3.591 & 0.488 & -24.484 & 3.384 \\
\hline & 8 & -13.354 & 4.692 & 0.603 & -31.557 & 4.849 \\
\hline & 10 & -23.233 & 9.199 & 1 & -58.925 & 12.458 \\
\hline & 11 & $-71.988^{*}$ & 17.66 & 0.031 & -140.507 & -3.468 \\
\hline & 12 & $-95.146^{*}$ & 23.22 & 0.029 & -185.24 & -5.052 \\
\hline & 1 & -48.09 & 15.323 & 0.304 & -107.545 & 11.364 \\
\hline & 2 & -73.667 & 21.375 & 0.145 & -156.602 & 9.269 \\
\hline & 3 & -83.171 & 22.025 & 0.065 & -168.627 & 2.285 \\
\hline & 4 & -48.288 & 18.075 & 0.9 & -118.418 & 21.843 \\
\hline & 5 & -1.967 & 6.889 & 1 & -28.695 & 24.761 \\
\hline \multirow[t]{11}{*}{10} & 6 & 8.733 & 6.26 & 1 & -15.553 & 33.02 \\
\hline & 7 & 12.683 & 6.154 & 1 & -11.193 & 36.56 \\
\hline & 8 & 9.879 & 5.511 & 1 & -11.502 & 31.261 \\
\hline & 9 & 23.233 & 9.199 & 1 & -12.458 & 58.925 \\
\hline & 11 & -48.754 & 15.345 & 0.277 & -108.294 & 10.786 \\
\hline & 12 & -71.913 & 20.528 & 0.126 & -151.562 & 7.737 \\
\hline & 1 & 0.664 & 4.704 & 1 & -17.586 & 18.914 \\
\hline & 2 & -24.913 & 13.643 & 1 & -77.848 & 28.023 \\
\hline & 3 & -34.417 & 10.915 & 0.294 & -76.766 & 7.933 \\
\hline & 4 & 0.467 & 19.328 & 1 & -74.526 & 75.459 \\
\hline & 5 & 46.788 & 14.043 & 0.191 & -7.7 & 101.275 \\
\hline \multirow[t]{11}{*}{11} & 6 & $57.488^{*}$ & 14.274 & 0.035 & 2.107 & 112.868 \\
\hline & 7 & $61.438^{*}$ & 15.488 & 0.04 & 1.344 & 121.531 \\
\hline & 8 & $58.633^{*}$ & 14.818 & 0.041 & 1.142 & 116.125 \\
\hline & 9 & $71.988^{*}$ & 17.66 & 0.031 & 3.468 & 140.507 \\
\hline & 10 & 48.754 & 15.345 & 0.277 & -10.786 & 108.294 \\
\hline & 12 & -23.158 & 12.744 & 1 & -72.606 & 26.289 \\
\hline & 1 & 23.822 & 15.599 & 1 & -36.701 & 84.345 \\
\hline & 2 & -1.754 & 16.768 & 1 & -66.813 & 63.304 \\
\hline & 3 & -11.258 & 14.062 & 1 & -65.818 & 43.301 \\
\hline & 4 & 23.625 & 12.837 & 1 & -26.183 & 73.433 \\
\hline & 5 & $69.946^{*}$ & 17.598 & 0.04 & 1.665 & 138.226 \\
\hline \multirow[t]{6}{*}{12} & 6 & 80.646 & 21.287 & 0.063 & -1.948 & 163.24 \\
\hline & 7 & $84.596^{*}$ & 20.829 & 0.032 & 3.779 & 165.413 \\
\hline & 8 & 81.792 & 21.302 & 0.055 & -0.858 & 164.441 \\
\hline & 9 & $95.146^{*}$ & 23.22 & 0.029 & 5.052 & 185.24 \\
\hline & 10 & 71.913 & 20.528 & 0.126 & -7.737 & 151.562 \\
\hline & 11 & 23.158 & 12.744 & 1 & -26.289 & 72.606 \\
\hline
\end{tabular}

Table 17: Pairwise comparisons test based on estimated marginal means. ${ }^{*}$ signifies the 
mean difference is significant at the .05 level. ${ }^{\mathrm{b}}$ is adjustment for multiple comparisons: Bonferroni.

\subsection{Model Accuracy Evaluation}

In order to assess the accuracy of the FARSITE model in this study, fire simulations were made to match fire scars from previous fires in SLM. The first fire assessed occurred on March 23, 2008 while the second fire occurred on April 12 and April 13, 2011.

The fire that occurred on March 23, 2008 burnt an area of 99.5 hectares (Figure 17). The fire was spotted around 11:00am in the morning and was believed to have started around 10:00am. The fire was fully extinguished by the local brigade by $3: 00 \mathrm{pm}$.

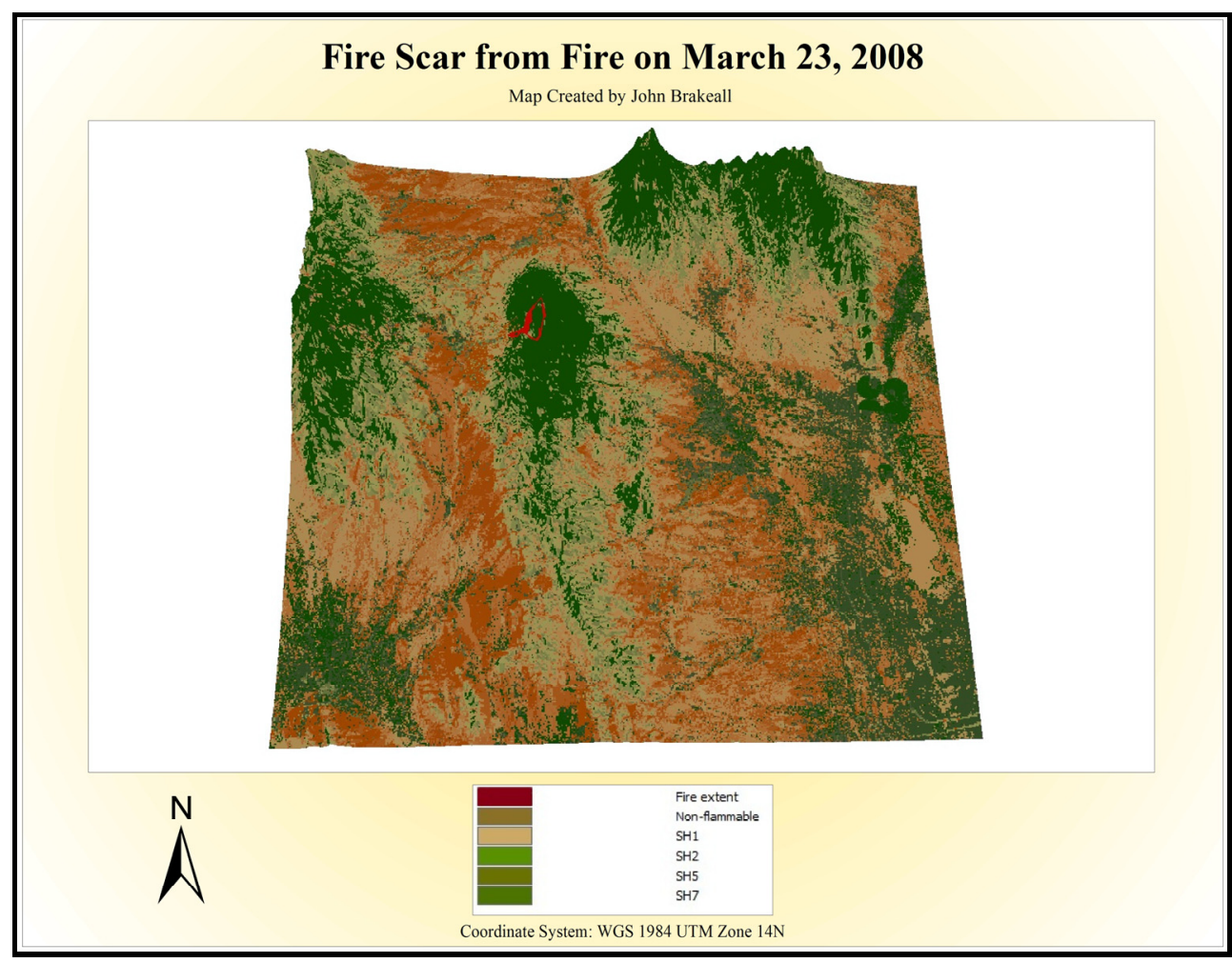

Figure 17: Actual extent of fire that occurred on March 23, 2008. Fire burned 99.5 hectares. 
A fire simulation using FARSITE was conducted for March 23, 2008 from 10:00am to 3:00pm (Figure 18). The simulation produced an area burnt of 229.6 hectares, which was $131 \%$ larger than the actual fire. These findings would suggest that the model is severely overestimating the rate of fire spread in SLM.

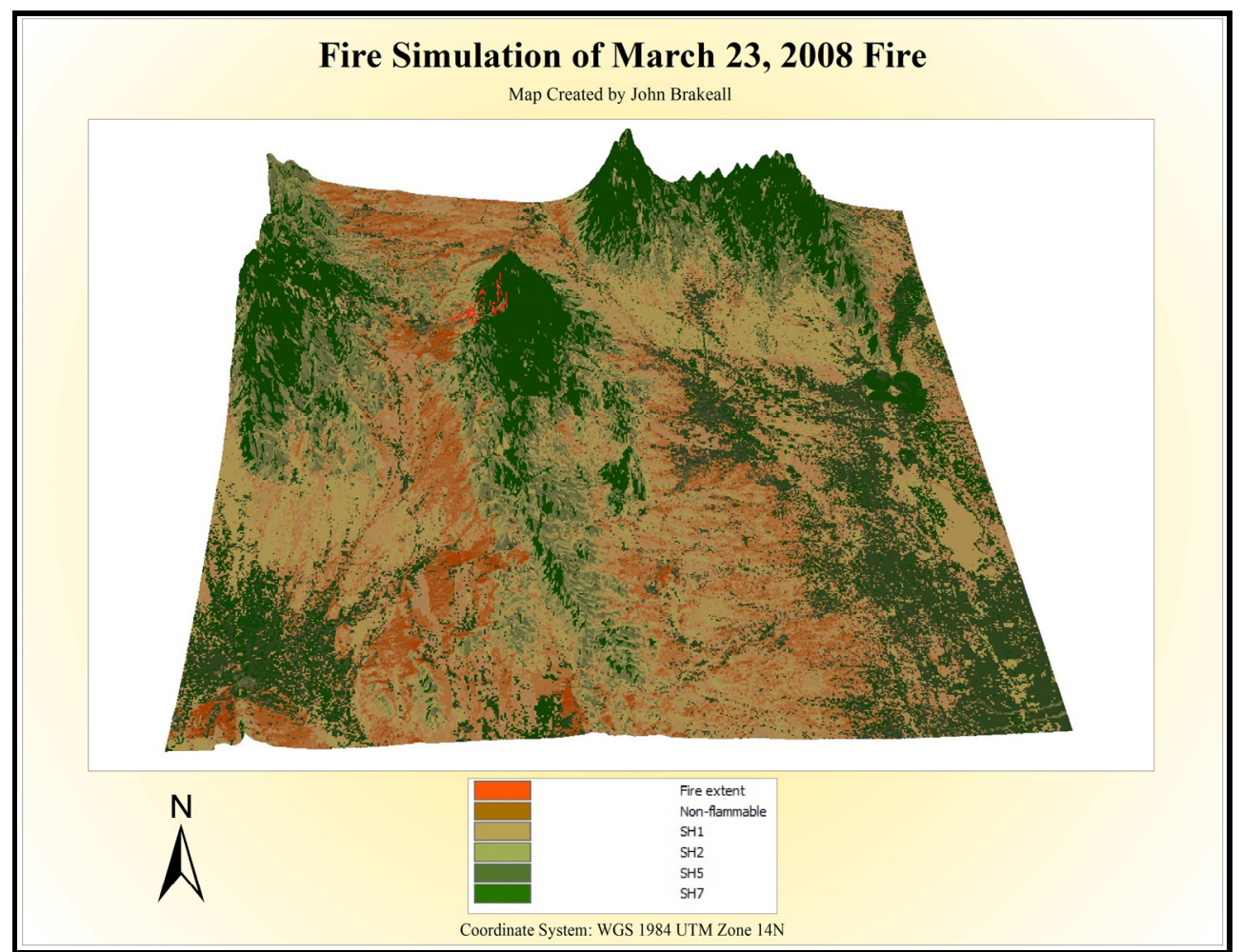

Figure 18: Simulation of fire that occurred on March 23, 2008. Simulated fire burned 229.6 hectares.

The issue of overestimation is common for the FARSITE program. As a result, an adjustment file can be added to tune the results to more accurately fit observed or expected results from the user. The FARSITE user's manual explains how the adjustment factor chosen should reciprocate the under or overestimation (Finney, 1998). For example, if the spread rate is double the expected, one should use an adjustment factor of 0.050 (Ibid). A second fire simulation was run for March 23, 2008 with an adjustment factor of 0.43 (Figure 19). The 0.43 value was chosen because it reciprocates the $131 \%$ 
overestimation of the simulation. The simulation with the 0.43 adjustment factor produced an area burnt of 52.2 hectares, which is $48 \%$ smaller than the actual area burnt (Figure 20).

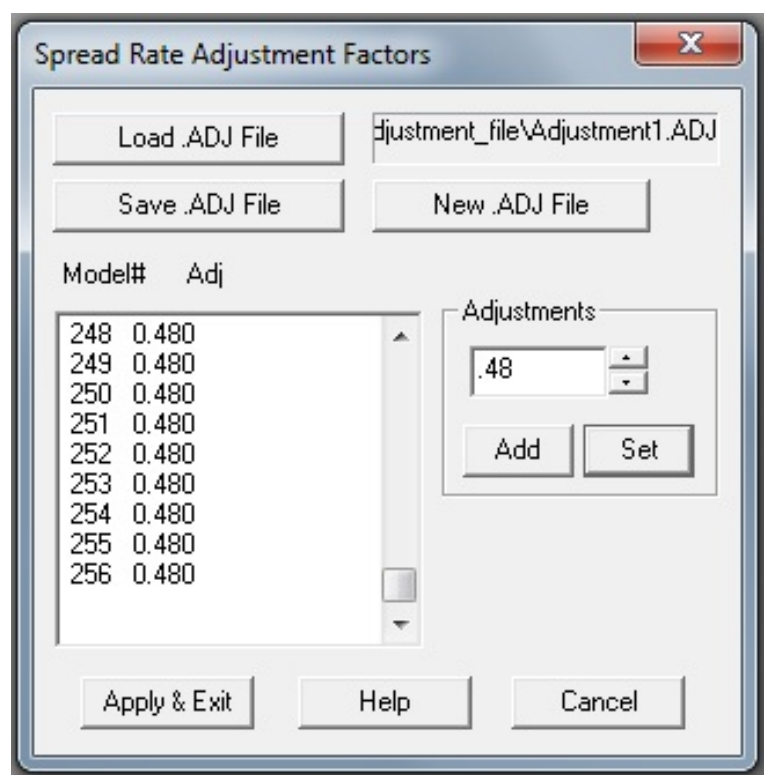

Figure 19: Spread rate adjustment file created for March 23, 2008 fire simulation. 


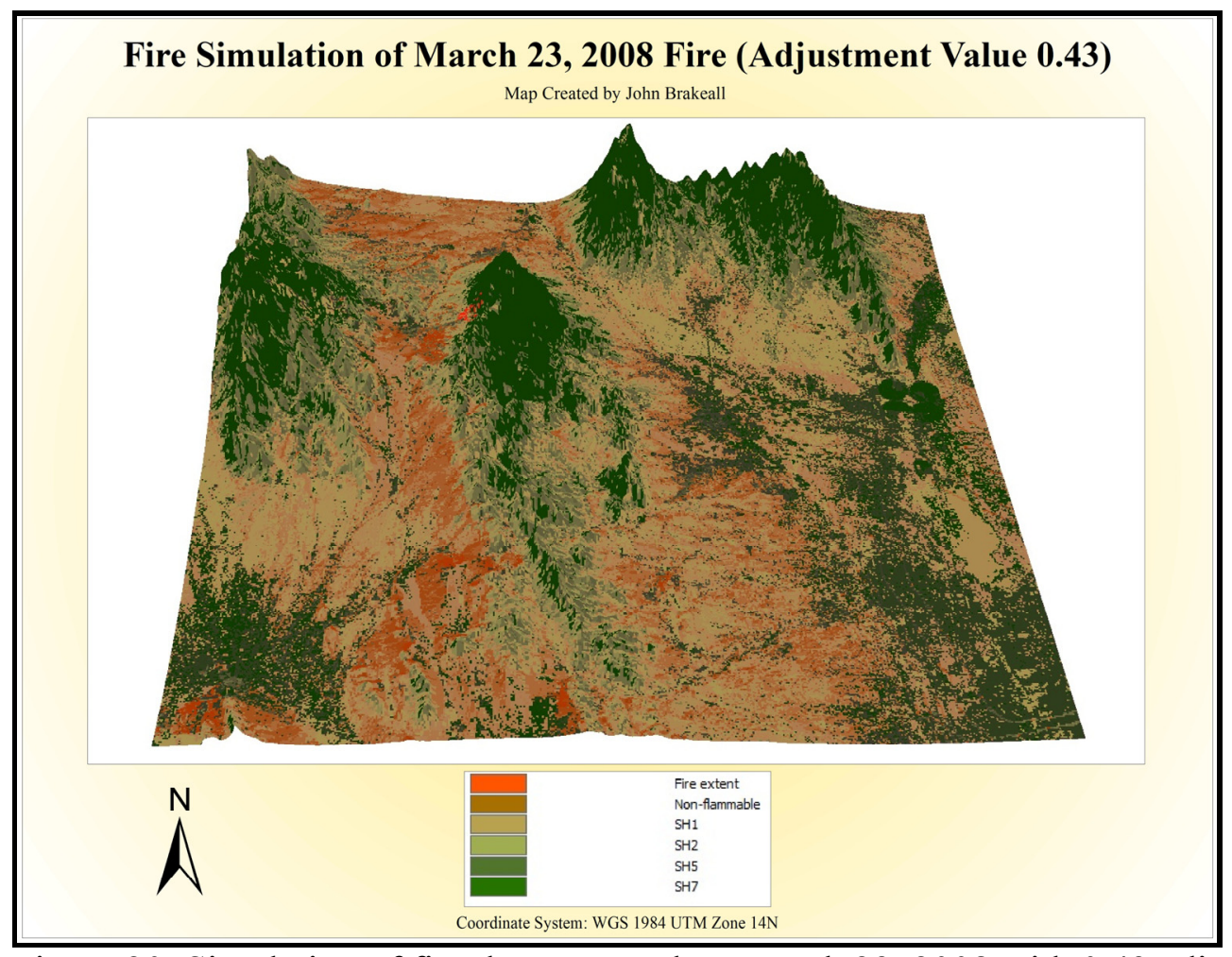

Figure 20: Simulation of fire that occurred on March 23, 2008 with 0.43 adjustment value. Simulated fire burned 52.2 hectares.

To better assess the accuracy of the FARSITE model in SLM, several iterations were run to find the best adjustment factor. In this study, ad adjustment factor of 0.55 proved to be the most effective. The actual fire burned 99.5 hectares and fire simulations using a 0.55 adjustment factor produce a fire of 100.7 hectares, which is an overestimation of $1.2 \%$ (Table 18$)$.

\begin{tabular}{|c|c|c|}
\hline \multicolumn{3}{|c|}{ Fire Simulation: March 23, 2008 } \\
\hline Adjustment factor & Fire size (hectares) & Accuracy \\
\hline 0.53 & 86.6 & $-13.0 \%$ \\
\hline 0.54 & 90.4 & $-9.1 \%$ \\
\hline 0.545 & 91.1 & $-8.4 \%$ \\
\hline 0.55 & 100.7 & $+1.2 \%$ \\
\hline 0.56 & 117.3 & $+17.9 \%$ \\
\hline
\end{tabular}

Table 18: Iterations with various adjustment factors for the March 23, 2008 fire. 
The fire that occurred on April 12/13, 2011 burnt an area of 286.4 hectares

(Figure 21). The fire was initiated around 5:00 PM in the evening on April 12, 2011 and was fully extinguished by the local brigade by 4:00pm on April 13, 2011 .

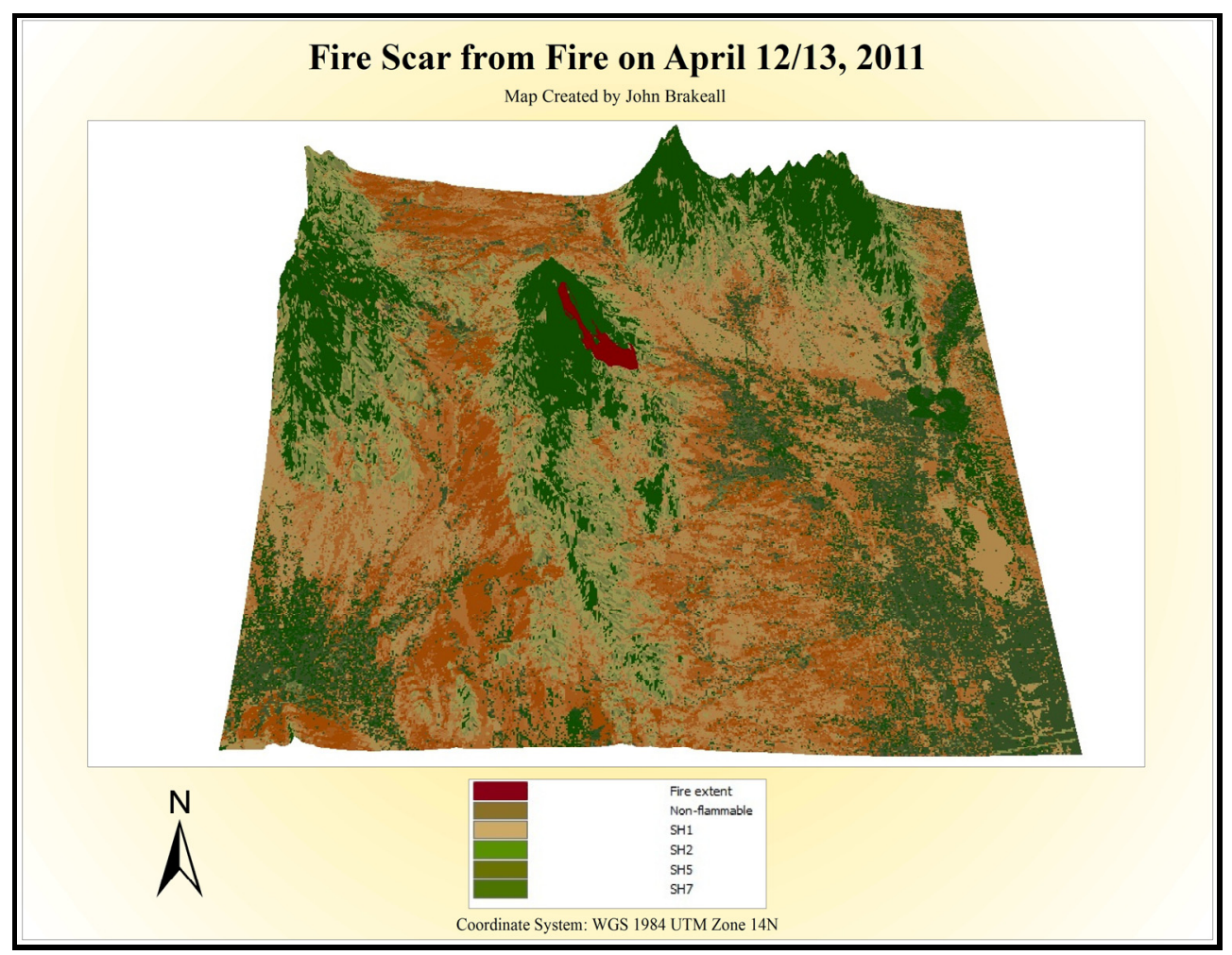

Figure 21: Actual extent of fire that occurred on April 12/13, 2011. Fire burned 286.4 hectares.

A fire simulation using FARSITE was conducted that started at 5:00pm on April 12, 2011 and lasted until 4:00pm on April 13, 2011 (Figure 22). The simulation produced an area burnt of 592.6 hectares, which was $107 \%$ larger than the actual fire. These findings would also suggest that the model is again severely overestimating the rate of fire spread in SLM. 


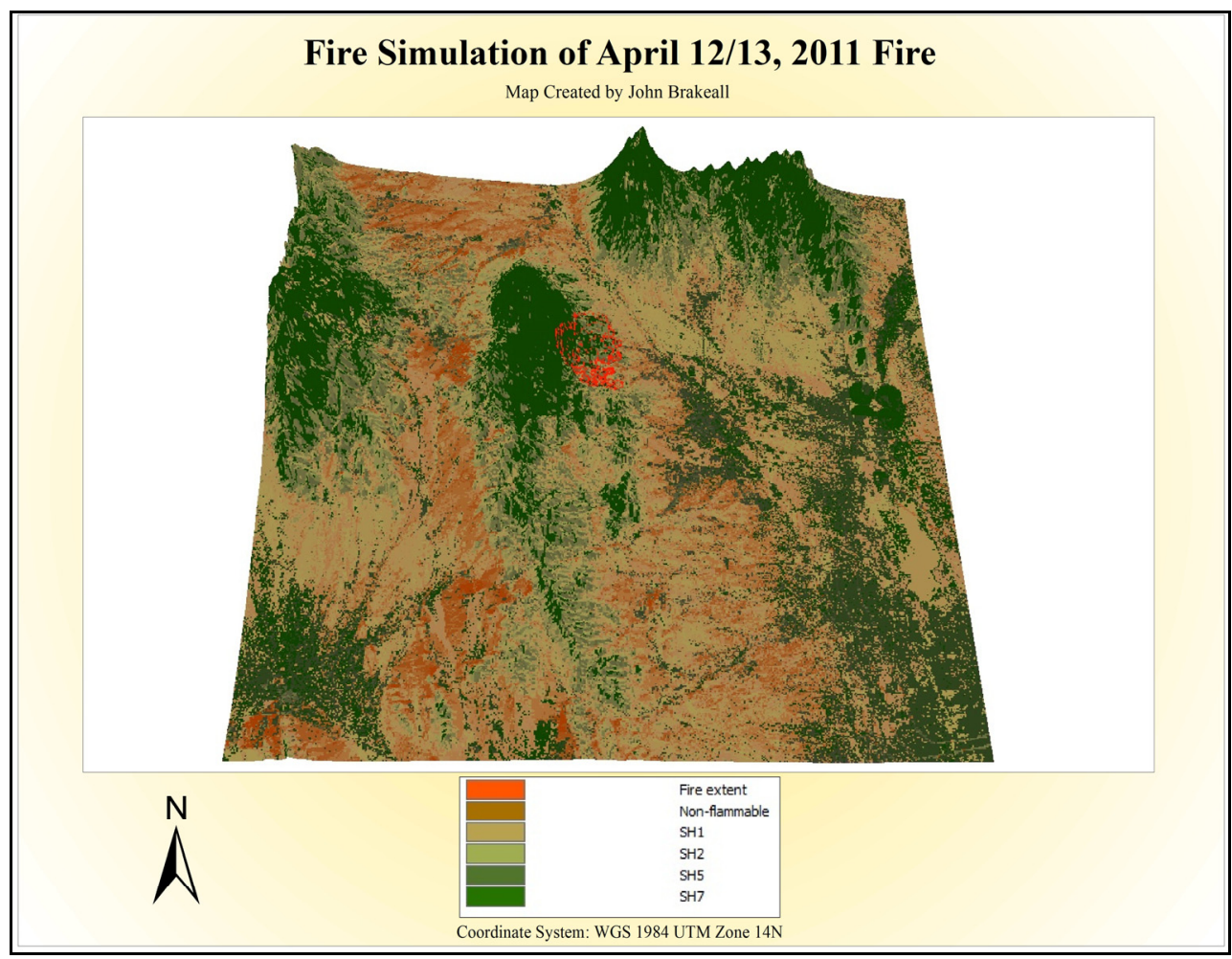

Figure 22: Simulation of fire that occurred on April 12/13, 2011. Simulated fire burned 592.6 hectares.

A second fire simulation was run for April 12/13, 2011 with an adjustment factor of 0.48 (Figure 23). The 0.48 value was chosen because it reciprocates the $107 \%$ over prediction of the simulation. The simulation with the 0.48 adjustment factor produced an area burnt of 222.1 hectares, which is $22 \%$ smaller than the actual area burnt. 


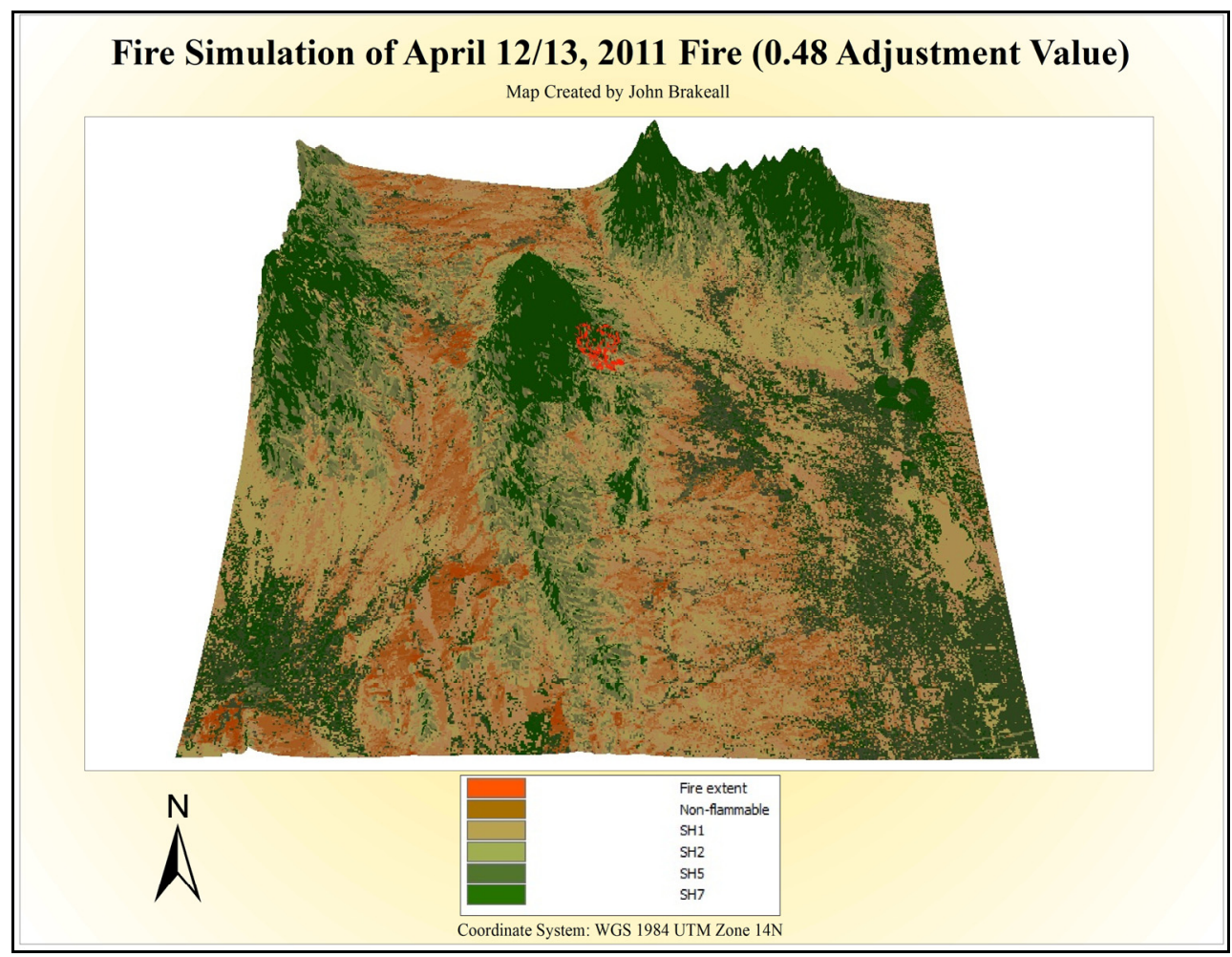

Figure 23: Simulation of fire that occurred on April 12/13, 2011 with 0.43 adjustment factor. Simulated fire burned 52.2 hectares.

To better assess the accuracy of the FARSITE model, several iterations were run to find the best adjustment factor. In this study, ad adjustment factor of 0.505 proved to be the most effective. The actual fire burned 286.4 hectares and fire simulations using a 0.505 adjustment factor produce a fire of 297.5 hectares, which is an overestimation of $3.9 \%$ (Table 19).

\begin{tabular}{|c|c|c|}
\hline \multicolumn{3}{|c|}{ Fire Simulation: April12/13, 2008 } \\
\hline Adjustment factor & Fire size (hectares) & Accuracy \\
\hline 0.48 & 222.1 & $-23.0 \%$ \\
\hline 0.49 & 234.2 & $-18.2 \%$ \\
\hline 0.5 & 250.5 & $-12.5 \%$ \\
\hline 0.505 & 297.5 & $+3.9 \%$ \\
\hline 0.51 & 298.6 & $+4.3 \%$ \\
\hline 0.52 & 335.4 & $+17.0 \%$ \\
\hline
\end{tabular}

Table 19: Iterations with various adjustment factors for the April 12/13, 2011 fire. 
The FARSITE fire model overestimated fire spread rates by $131 \%$ and $107 \%$ for the March 23, 2008 and April 12/13, 2011 fires, respectively. However, when an adjustment factor file of 0.55 and .505 were used, the FARSITE model overestimated fire spread rates by 1.2\% and 3.9\% for the March 23, 2008 and April 12/13, 2011 fires, respectively. These findings suggest that adjustment factor files can be used to accurately model fire, but must be precisely calibrated.

\section{CHAPTER 5}

\section{DISCUSSION AND CONCLUSION}

\subsection{Study Conclusions}

The results of this study suggest that firebreaks are 100\% effective at stopping fire. These are pleasing results for the management of SLM, especially considering the model overestimates fire, according to this study. However, the locality of these firebreaks also needs to be taken into consideration. The Los Encinos firebreak is located in a low-lying area that is mostly composed of $\mathrm{SH} 1$ or $\mathrm{SH} 2$ vegetation. The average size of fire after a 23 -hour simulation was 1.5 hectares. This would suggest that fire is not a threat in this area anyway. This firebreak was an abandoned road and was created during 2009 because the fire budget was tight. There is little vegetation in this area and the slope is not great. Firebreaks should only be constructed in areas where they will be effective.

This study will help SLM answer questions in regards to the efficacy of firebreaks against fires. However, there are many other factors that must be taken into consideration with these firebreaks. Primarily, making sure that firebreaks are located in areas that are fire prone is of great importance. The Los Encinos firebreak is located at the periphery of 
the town of Los Encinos, which serves as a great buffer against anthropogenic fires that may break out in the community. However, it is largely located in areas that contain SH1 and $\mathrm{SH} 2$ vegetation cover where the threat of fire is negligible. It is crucial to construct firebreaks in areas of SH5 or SH7 vegetation where fire actually poses a serious threat. Moreover, these firebreaks should be constructed in areas that are not easily accessible with trucks or all-terrain vehicles. All three firebreaks were constructed in areas that are relatively easy to access with a motorized vehicle. Meanwhile, many places within SLM have steep slopes and can only be accessed by traveling up to one hour by foot. These areas must be of high concern and priority for firebreaks as they would be the only resistance against high intensity wildfire.

The results revealed that the SH5 vegetation type experienced the fastest rate of fire spread. This did not correlate with the hypothesis of the study as the SH7 vegetation type was hypothesized to experience the fastest rate of fire spread. The SH7 vegetation type contains the most biomass with 6.9 tons of fire fuel per hectare. However, much of the biomass in this vegetation class is attributed to large shrubs and pine species like Pinyon pine (Pinus cembroides) and Ponderosa pine (Pinus ponderosa). In order for a canopy fire to develop in these species, it would require a considerable amount of time. Pine forests contain a great deal of secondary growth, or 'wood', which takes considerable time to burn. Perhaps the 6-hour simulations that were run in this study did not provide sufficient time for crown fires to develop in the SH7 vegetation model. Even if the crown fires did develop, the spread rate may not be an accurate way to assess damage. The fires that occurred in the SH7 vegetation may have consumed more biomass, but less area. 
The results revealed that the month of March experienced the fastest rate of fire spread $(M=117.250)$. This did not exactly correlate with the hypothesis of the study as April was expected to experience the fastest rate of fire spread $(\mathrm{M}=82.367)$. The average daily temperature in April $\left(19.60^{\circ} \mathrm{C}\right)$ is warmer than March $\left(16.52^{\circ} \mathrm{C}\right)$. However, the average rainfall is substantially higher in April $\left(0.86 \mathrm{~mm}_{\text {day }}{ }^{-1}\right)$ than March $(0.58 \mathrm{~mm}$ day $\left.^{-1}\right)$. It is difficult to assess the exact effect of weather data, as the FARSITE algorithm is complex. However, the FARSITE user's manual summarizes some of the complexities of the FARSITE model. The trends of higher humidity with lower temperatures leads to decreased fire intensity (Finney, 1998). This is confirmed by the findings in this study. March had the greatest average size of fire (117.250 ha.) followed by February (107.746 ha.) and December (105. 992 ha.). Upon further review, these findings correlate with the literature. The dry winter is the most vulnerable season for large, catastrophic fires. The month of March is the most vulnerable.

The results of this study also reveal that September experienced the slowest average rate of fire spread (10.846 ha.). The average daily temperature in September is $19.59^{\circ} \mathrm{C}$, which is $18.6 \%$ higher than the March average (Servicio Meteorológical Nacional, 2010). However, the average rainfall in September of $2.81 \mathrm{~mm} \mathrm{day}^{-1}$ is $384 \%$ higher than the $0.58 \mathrm{~mm} \mathrm{day}^{-1}$ in March (Ibid). This $384 \%$ increase in precipitation would have a substantial effect on fuel moisture. September, a month of high humidity, is the most ideal time to implement prescribed burns and March, a month of low humidity, is the month most vulnerable to large catastrophic fire. 


\subsection{Limitations of Results}

The study area in this study had complex topography. Many areas were flat while some of the mountains had slopes as great as $49^{\circ}$. As a result, there were likely considerable anisotrophic effects in the satellite image used in this study. Anisotrophic effects are variations in the spectral response of a complex surface (Tottrup, 2007). Due to anisotrophic effects, a non-Lambertian Minnaert's topographic correction was carried out. The results of this topographic correction can have minimal efficacy when surfaces have great complexity like in this study (Ibid). Linear mixture modeling (LMM) would be an ideal method for correcting anisotrophic effects in images that contain pixels of mixed composition, like in this study (Ibid). LMM is a measure that corrects surface level reflectance per pixel. The end result is a set of images that contain corrected reflectance values for each individual pixel in the image (Ibid).

The FARSITE model grossly over-predicted fire rate spread in this study without a spread rate adjustment file. This may lead one to believe that the FARSITE model and its fuel models cannot be applied to SLM or the Chihuahua desert of Mexico. However, this may not be true. The adjustment file allows the user to calibrate the rate of fire spread for each fuel model based on observed or predicted fire patterns within the study area. The adjustment file is a floating-point value $(>0)$ that is multiplied by the rate of fire spread and is used commonly in FARSITE applications to tune fuel models (Davis et al., 2010). The adjustment factors of 0.55 and 0.505 most accurately simulated fires from March 23, 2008 and April12/13, 2008, respectively. This suggests that an adjustment factor could be used to accurately model fire in SLM, but further work must be conducted in order to calibrate precise adjustment factors for each fuel model. More iterations would 
need to be made within each vegetation type to find the best value for each fuel model. In future studies I will employ the model accuracy evaluation first to find appropriate adjustment values for each vegetation class.

The FARSITE program requires users to manually find adjustment factors through trial and error. The FARSITE program should create a type of recursive algorithm that continuously compiles values until the desired output value is reached. This would allow fire management professionals to accurately find adjustment factors in a timelier manner.

The FARSITE model grossly over-predicted fire rate spread in this study. This is a common issue with the FARSITE model (Finney, 1998). As stated in the FARSITE user's manual, all fuel models tend to over-predict fire spread rate (Rothermel, 1972). Simulating fire over large distances or time often over predicts fire size due to the coarse spatial and temporal scale of the data (Ibid). The model assumes homogeneity when there may be small-scale variables that would slow or stop fire. This is an inherent problem with the model. Many studies use data with a resolution of 30-meter, as the data can generally be obtained free of charge. However, other studies have been conducted using high-resolution data with prominent results. In particular, a study by Mutlu et al. was conducted that integrated 2.5-meter resolution QuickBird and LIDAR data (2008). The cost of the data was $\$ 36,536$, but lead to significantly more accurate results (Ibid). The cost of the data was significantly less than the cost of land lost due to fire (Ibid). Accurate data may be expensive, but can be justified, as it is essential to the accuracy of FARSITE results. The findings from this study suggest that SLM should consider obtaining higher quality data in order to retrieve more accurate results from FARSITE fire modeling. 
The fuel data in the study were obtained on the basis of an image from 2008, while the meteorological data was from 2003. The discretion in the fuel models, as well as the temporal discrepancies between the satellite image from 2008 and meteorological data from 2003 are significant sources of potential error. A current satellite image is necessary because a recent fire would consume the fuel in the area and render the area incombustible from fire.

In this study, model accuracy was assessed on the basis of total area burned.

Future research will need to measure the exact shape and location of the simulated fire vs. the actual fire and use that as an additional metric of accuracy.

\subsection{Closing Remarks}

Mexico is the fifth most biologically diverse country in the world (Groombridge \& Jenkins, 2002) and the most biologically diverse in cacti (NPS, 2002). Wildfire has been a primary threat to ecology in Mexico and studies suggest that wildfires will pose a greater threat in the future with the exacerbation of climate change (Gebow \& Halverson, 2005). With this increasing threat, wildfire management in Mexico needs to adapt new technologies in an effort to make best management decisions with limited resources. FARSITE stands at the forefront of fire modeling in the United States as it integrates many aspects of fire behavior that other programs neglect and should be used as a management tool in Mexico (Keane et al., 2000).

This study provides a solid foundation for wildfire management with innovative geospatial technologies and, in particular, FARSITE fire modeling in SLM and CONANP of Mexico. Further research and work needs to be done in order to obtain more accurate results. It is imperative that future forest fires are well documented and 
simulated in FARSITE to better calibrate adjustment factors to reflect wildfire in SLM.

Ideally, custom fuel models should be created for the various vegetation types throughout SLM. 


\section{REFERENCES}

Abella, S.R.; Engel, E.C.; Lund, C.L.; Spencer, J.E. (2009). Early post-fire plant establishment on a Mojave Desert burn. Faculty Publications, SEPA, 72.

Agee, J.K.; Bahro, B.; Finney, M.A.; Omi, P.N.; Sapsis, D.B.; Skinner, C.N.; van Wagtendonk, J.W.; Weatherspoon, C.P. (2000). The use of shaded fuelbreaks in landscape fire management. Forest Ecology and Management, 127, 55-66.

Albini, F.A. (1976). Estimating wildfire behavior and effects (General Technical Report INT-30). Ogden, Utah: Intermountain Forest and Range Experiment Station, USDA Forest Service.

Albini, F.A. (1979). Spot fire distance from burning trees- a predictive model (General Technical Report INT-56). Ogden, Utah: Intermountain Forest and Range Experiment Station, USDA Forest Service.

Albini, F.A. \& Baughman, R.G. (1979). Estimating windspeeds for predicting wildland fire behavior (Forest Service Research Paper INT-221). Ogden, Utah: Intermountain Forest and Range Experiment Station, USDA Forest Service.

Anable, M.E.; McClaran, M.P.; Ruyle, G.B. (1992). Spread of introduced Lehmann's lovegrass (Eragrostis lehmanniana Nees.) in southern Arizona, USA. Biological Conservation, 61, 181-188.

Anderson, D.H.; Catchpole, E.A.; DeMestre, N.J.; Parkes, T. (1982). Modeling the spread of grass fires. Journal of Australian Mathematical Society, 23, 451-466.

Andrews, P.L. (2007) BehavePlus fire modeling system: Past, present, and future. In 'Proceedings of 7th Symposium on Fire and Forest Meteorological Society'. 23-25 October 2007, Bar Harbor, Maine.

Andrews, Pat. Personal communication. July 30, 2012.

Ansley, Jim. Personal communication. November 1'2011.

Arroyo, L.A.; Pascual, C.; Manzanera, J.A. (2008). Fire models and methods to map fuel types: The role of remote sensing. Forest Ecology and Management, 256, 1239-1252.

Associated Press. (February 8, 2009). 108 Killed in Deadliest-ever Australian Wildfires. Retrieved from: $<$ http://www.ap.org $>$

Baker, J.; Briggs, S.; Gordon, V.; Jones, A.; Settle, J.; Townshend, J.; Wyatt, B. (1991). Advances in classification for land cover mapping using SPOT HRV imagery. International Journal of Remote Sensing, 12(5), 1071-1085. 
Bodrožić, L; Marasović, J; Stipaničev, D. (2005). Fire Modeling in Forest Fire Management. Proceedings of International Conference CEEPUS Spring School Engineering for the Future, Kielce, Poland.

Brooks, M.L. (2000). Competition between alien annual grasses and native annual plants in the Mojave Desert. American Midland Naturalist, 144, 92-108.

Brooks, M. L. \& Pyke, D.A. (2001). Proceedings of the Invasive Species Workshop: The Role of Fire in the Spread and Control of Invasive Species (Miscellaneous Publication No. 11). Tallahassee, FL: Tall Timbers Research Station.

Burgan, R. \& Rothermel, R.C. (1984). BEHAVE: Fire Behavior Prediction and Fuel Modeling System-FUEL Subsystem (Rep. No. GTR INT-167). Ogden, Utah: Intermountain Forest and Range Experiment Station, USDA Forest Service.

Cárdenas, L. (December 16, 2011) Cuesta 394 mdp combate de incendios. Reforma, p 12.

Castro, R. \& Chuvieco, E. (1998). Modeling forest fire danger from geographic information systems. Geocarto International, 13, 15-23.

Chihuahuan Desert Education Coalition. (November 12, 2011) About: The Chihuahuan Desert- Hot Spot for Conservation in North America. Retrieved from: $<$ http://www.chihuahuandesert.org/cdecaboutus.html $>$

Cohan, L. \& Burnett, H.S. (September 10, 2008). In Order to Extinguish Forest Fires, Don't Let Logging Burn Out (Brief Analysis No. 631). National Center for Policy Analysis.

Colby, J. D. (1991). Topographic Normalization in Rugged Terrain. Photogrammetric Engineering \& Remote Sensing 57, 5, 531-537.

Commission for Environmental Cooperation. (November 7, 2011) Regional alliance to promote conservation and sustainable use of Chihuahuan desert grasslands. Retrieved from: <http://www.cec.org/Page.asp?PageID=122\&ContentID=3147>

Comisión Nacional de Áreas Naturales Protegidas. (1981)."Decreto por el que por causa de interés publico se establece zona de protección forestal y refugio de la fauna silvestre, la región conocida como Sierra La Mojonera localizada en el Municipio de Vanegas, S.L. P., dentro de una superficie aproximada de 9,251,500 Has." Sierra La Mojonera. 
Comisión Nacional de Áreas Naturales Protegidas. (November 2, 2011). Quienes Somos? Comisión Nacional de Áreas Naturales Protegidas. Retrieved from: $<\mathrm{http}: / /$ www.conanp.gob.mx/quienes_somos/>

Comisión Nacional Forestal. (2011). Reporte semanal de resultados de incendios forestales.

Cox, J.R.; Ruyle, G.B.; Roundby, B.A. (1990). Lehmann lovegrass in southeastern Arizona: biomass production and disappearance. Journal of Range Management, 43, 367-372.

Cross, J. (September 14, 2011). Radiometric Correction of Satellite Images: When and Why Radiometric Correction is Necessary. The University of Toledo. Retrieved from: $<$ http://remotesensing.utoledo.edu/pdfs/less2/Lesson04NQ.pdf $>$

Davis, B.; Miller, C.; Parks, S. (2010) Retrospective Fire Modeling: Quantifying the Impacts of Fire Suppression (Technical Report: RMRS-GTR-236. Rocky Mountain Research Station, Colorado: United States Forest Service.

Doerr, S.H.; Shakesby, R.A.; Walsh, R.P. (2000). Soil water repellency; its causes, characteristics and hydro-geomorphological significance. Earth-Science Reviews, 51, 33-65.

Duguy, B.; Alloza, J.; Vallejo, R.; Roder, A.; Hill, J. (2007). Modeling the effects of landscape fuel treatments on fire growth and behavior in a Mediterranean landscape (eastern Spain). International Journal of Wildfire, 16, 619-632.

Duncan, B.W. \& Schmalzer, P.A. (2004). Anthropogenic influences on potential fire spread in a pyrogenic ecosystem of Florida, USA. Landscape Ecology, 19, 153-165.

Eissenstat, D.M., \& Caldwell, M.M. (1988). Competitive ability is linked to rates of water extraction. Oecologia, 75, 1-7.

Elton, C.S. (1958). The ecology of invasions by animals and plants. London, United Kingdom: Methuen.

ERDAS, Inc. (1999). ERDAS Field Guide. Fifth Edition. Atlanta, Georgia: Headquarters, ERDAS, Inc.

Esque, T.C.; Young, J.A.; Tracy, R.C. (2010). Short-term effects of experimental fires on a Mojave Desert seed bank. Journal of Arid Environments, 74, 1302-1308.

Findley, J. S. \& Caire, W. (1974). The status of mammals in the northern region of the Chihuahuan Desert (Transactions and Proceedings Series, 3). Alpine Texas: United States National Park Service. 
Finney, M.A. (1994). Modeling the spread and behavior of prescribed natural fires. In Proceedings of the twelfth conference on fire and forest meteorology, edited by J. D. Cohen, J. M. Saveland, and D. D. Wade, 138-43. Bethesda, MD: Society of American Foresters.

Finney, M.A. (1998). FARSITE: Fire Area Simulator- Model Development and Evaluation (Research Paper RMRS-RP-4) Ogden, Utah: Rocky Mountain Research Station, USDA Forest Service.

Finney, M.A. \& Andrews, P.L. (1999). FARSITE: A Program for Fire Growth Simulation. Fire Management, 59(2), 13-15.

Finney, M.A. (2001). Design of regular landscape fuel treatment patterns for modifying fire growth and behavior. Forest Science, 47(2), 219-228.

Fire Research \& Management Exchange System. (2010). Unit 1: Introduction Geospatial Fire Analysis, Interpretation, \& Application. S-495 Geospatial Fire Analysis Interpretation Application, 13.

Fleischner, T. L. (1994). Ecological costs of livestock grazing in western North America. Conservation Biology, 8, 629-644.

Food and Agriculture Organization of United Nations. (2001). Global forest fire assessment 1990-2000 (Forest Resources Assessment-WP 55). Rome: Food and Agriculture Organization.

French, I.A. (1992). Visualization techniques for the computer simulation of bushfires in two dimensions. M.S. thesis, University of New South Wales, Australian Defense Force Academy, 140.

Fulé, P.Z. (2008). Does It Make Sense to Restore Wildland Fire in Changing Climate. Restoration Ecology, 16(4), 526-531.

Gebow, B.S. \& Halvorson, W.L. (2005). Managing fire in the Northern Chihuahuan Desert: A Review and Analysis of the Literature (Open-File Report. 2005-1157). Flagstaff, Arizona: Southwest Biological Science Center, United States Geological Survey.

Green, L.R. (1977). Fuelbreaks and other fuel modification for wildland fire control. (Agricultural Handbook: 499). Washington D.C.: United States Forest Service.

Groombridge, B. \& Jenkins, M.D. (2002). World Atlas of Biodiversity. University of Los Angeles, CA: California Press. 
Havstad, K.M. \& James, D. (2010). Prescribed burning to affect a state transition in a shrub-encroached desert grassland. Journal of Arid Environments, 74, 1324-1328.

Hernandez, H.M. \& Godinez, H.A. (1994). Contribucion al conocimiento de las cactaceas Mexicanas amenazadas. Acta Botánica Mexicana, 26, 33-52.

Hollingsworth, L.T.; Kurth, L.L.; Parresol, B.R.; Ottmar, R.D.; Prichard, S.J. (2012). A comparison of geospatially modeled fire behavior and fire management utility of three data sources in the southeastern United States. Forest Ecology and Management, 273, 43-49.

Howell, D.C. (2010). Statistical Methods for Psychology ( $7^{\text {th }}$ edition). Belmont, CA: Wadsworth.

Hoyt, C.A. (2002).The Chihuahuan Desert: Diversity at Risk (Endangered Species Bulletin Volume 27. No. 2). Fort Davis, Texas: Chihuahuan Desert Research Institute.

Humphrey, R.R. (1958). The desert grassland: a history of vegetational change and an analysis of causes. Botany Review, 24, 193-252.

Hudson, B. (1991). Business and the Law: The Future of Mexico's Ejido System Likely to Remain Uncertain. Business Mexico, 5, 34.

INEGI. (2009). Prontuario de información geográfica municipal de los Estados Unidos Mexicanos. "Matehuala, San Luis Potosí. Clave geoestadística 24020.

Ingalsbee, T. (2010). Getting Burned: A Taxpayer's Guide to Wildfire Suppression Costs. Eugene, Oregon: Firefighters United for Safety, Ethics, and Ecology.

Inouye, R.S. (1980). Density-dependent germination response by seeds of desert annuals. Oecologia, 46, 235-238.

Johnston, M.C. (1977). Brief resume of botanical, including vegetational, features of the Chihuahuan Desert region with special emphasis on their uniqueness (Transactions and Proceedings Series No. 3. 335-359). Alpine, TX: U.S. Department of Interior, National Parks Service.

Justice C.O., Wharton S.W., Holben B.N. (1981). Application of digital terrain data to quantify and reduce the topographic effect on Landsat data. International Journal of Remote Sensing, 2(3), 213-230.

Kaufman, Y.J. (1989). The atmospheric effect on remote sensing and its correction.

Keane, R.E., Garner, J. L., Schmidt, K.M., Long, D. G., Menakis, J.P., Finney, M.A. (1998). Development of the Input Data Layers for the FARSITE Fire Growth Model 
for the Selway-Bitterroot Wilderness Complex, USA General Technical Report RMRS-GTR-3. 121). Ugden, Utah: USDA Forest Service.

Keane, R.E., Morgan, P. J., White, D. (1999). Temporal patterns of ecosystem processes on simulated landscapes in Glacier National Park, Montana, USA. Landscape Ecology, 14, 311-329.

Keane, R.E., Mincemoyer, S.A., Schmidt, K.M., Long, D.G., Garner, J.L. (2000). Mapping vegetation and fuels for fire management on the Gila National Forest Complex, New Mexico (General Technical Report RMRS-46-CD). Rocky Mountain Research Station, Missoula, MT: Unite States Forest Service.

Keane, R.E., Burgan, R.E., Van Wagtendonk, J.W. (2001). Mapping wildland fuels for fire management across multiple scales: Integrating remote sensing, GIS, and biophysical modeling. International Journal of Wildland Fire, 10, 301-319.

Keuchel, J., Naumann, S., Heiler, M., Siegmund, A. (2003). Automatic Land Cover Analysis for Tenerife by supervised classification using remotely sensed data. Remote Sensing of Environment, 86, 530-541.

Khumalo, G.; Holechek, J; Thomas, M; Molinar, F. (2008). Soil Depth and Climatic Effects on Desert Vegetation Dynamics. Rangeland Ecology Management, 61, 269274.

Kourtz, P. \& O'Reagan, W.G. (1971). A model for a small forest fire to simulate burned and burning areas for use in a detection model. Forensic Science International, 17(2), 163-169.

Kourtz, P.; Nozaki, P.; O'Regan, W. (1977). Forest fires in the computer- A model to predict the perimeter location of a forest fire (Inf. Rep. FF-X-65). Ottawa, Ontario: Fisheries and Environment Canada.

LANDFIRE. (2007). Landscape Fire and Resource Management Planning Tools Project. LANDFIRE Project. U.S. Department of Agriculture, Forest Service. Retrieved from: $<$ http://www.landfire.gov/index.php $>$

Loucks, O. (1970). Evolution of diversity, efficiency and community stability. American Zoologist, 10, 17-25.

Lillesand, T.M.; Kiefer, R.W.; Chipman, J.W. (2008). Remote Sensing and Image Interpretation (Sixth Edition). Untited States of America: John Wiley and Sons, Inc.

Liu, Y.; Stanturf, J.; Godrick, S. (2010). Trends in Global Wildfire Potential in a Changing Climate. Forest Ecology and Management, 259, 685-697. 
Lu, D.; Ge, H.; He, S.; Xu, A.; Zhou, G.; Du. H. (2008). Pixel-based Minnaert Correction Method for Reducing Topographic Effects on a Landsat 7 ETM Image. Photogrammetric Engineering \& Remote Sensing, 74(11), 1343-1350.

Ludwig, J.A.; Muldavin, E.; Blanche, R.K. (2000). Vegetation Change and Surface Erosion in Desert Grasslands of Otero Mesa, Southern New Mexico: 1982-1995. American Midland Naturalist, 144(20), 273-285.

Main, W.A.; Paananen, D.M.; Burgan, R.E. (1990). FIREFAMILY 1988 (General Technical Report NC- 138) St. Paul, MN: North Central Forest Experiment Station, United States Forest Service.

Mansourian, S.; Vallauri, D.; Dudley, N. (2005). Forest Reforestation in Landscapes: Beyond Planting Trees. New York: Springer.

Martin, S.C. (1983). Responses of semidesert grasses and shrubs to fall burning. Journal of Range Management, 36, 604-610.

Massada, A.B.; Radeloff, V.C.; Stewart, S.I.; Hawbaker, T.J. (2009). Wildfire risk in the wildland-urban interface: A simulation study in northwestern Wisconsin. Forest Ecology and Management, 258, 1990-1999.

McKell, C.M., Wilson, A.M., Kay, B.L. (1962). Effective burning of rangelands infested with medusahead. Weeds, 10, 125-131.

McPherson, G.R. (1995). The role of fire in the desert grass- lands. The Desert Grassland. Tucson, AZ: University of Arizona Press.

MEA. (2005). Millennium ecosystem assessment: ecosystems and human well-being: desertification synthesis. Washington, DC: World Resources Institute.

Melgoza, G. \& Nowak. R.S. (1991). Competition between cheatgrass and two native species after fire: Implications from observations and measurements of root distribution. Journal of Range Management, 44, 27-33.

Miller, J.D. \& Yool, S.R. (2002). Modeling fire in semi-desert grassland/oak woodland: the spatial implication. Ecological Modeling, 153(3), 229-245.

Mistry, J. \& Berardi, A. (2005). Assessing Fire Potential in a Brazilian Savanna Nature Reserve. Biotropica, 37(3): 439-451.

Molinar, F.; Holechek, J.; Galt, D.; Thomas, M. (2002). Soil Depth Effects on Chihuahuan Desert Vegetation. Western North American Naturalist, 62(3): 300-306. 
Murakami, T. (2007). Comparison of Minnaert Constants Based on Multi-Temporal SPOT/HRV Data for Three Forest Types. 新潟大学農学部研究報告 第 60 巻1号.

Mutlu, Muge; Popescu, Sorin C.; Zhao, Kaiguang. (2008). Sensitivity analysis of fire behavior modeling with LIDAR-derived surface fuel maps. Forest Ecology and Management, 256, 289-294.

National Parks Service. (May 25, 2009) Chihuahuan Desert Network. Inventory and Monitoring Program. Retrieved from: <http://science.nature.nps.gov/im/units/chdn/>

National Wildfire Coordinating Group. (January 1, 2010) Unit 7: Mid-term Geospatial Fire Analysis using FARSITE: Introduction to FARSITE (Unit 7: Lesson 1). Retrieved from:

$<$ http://www.frames.gov/portal/server.pt/community/fire_behavior/212/s-495/2840>

Nicholson, S.E.; Tucker, C.J.; Ba, M.B. (1998). Desertification, drought, and surface vegetation: an example from the West African Sahel. American Meteorological Society, 79, 815-29.

Nonomura, A.; Masuda, T.; Moriya, H. (2007). Wildfire damage evaluation by merging remote sensing with a fire area simulation model in Naoshima, Kagawa, Japan. Landscape \& Ecological Engineering, 3, 109-117.

Oerke, E.; Gerhards, R.; Menz, G.; Sikora, R. (2010). Precision Crop Protection- The Challenge and Use of Heterogeneity. Springer: New York.

Oldfield, S. (1997). Cactus and Succulent Plants. (Status Survey and Conservation Action Plan). Gland, Switzerland and Cambridge, UK: International Union and Conservation of Nature and Natural Resources.

Omi, P.N. (1996). The role of fuel breaks. In: Proceedings of the 17th Forest Vegetation Management Conference. Redding, CA. 89-96.

Omi, P.N.; Rideout, D.B.; Botti, S.J. (1999). An Analytical Approach for Assessing the Cost-Effectiveness of Landscape Prescribed Fires (General Technical Report. PSWGTR-173). Fort Collins, CO: Western Forest Fire Research Center, United States Forest Service.

Pake, C.E. (1993). Sonoran Desert annual plants: empirical tests of models of coexistence and persistence in a temporally variable environment. Ph.D. Dissertation, University of Arizona, Tucson.

Pase, C.P. (1971). Effect of a February fire on Lehmann lovegrass. Journal of Range Management, 24, 454-456. 
Paz, S.; Carmel, Y.; Jahshan, F.; Shoshany, M. (2011). Post-fire analysis of pre-fire mapping of fire risk: A recent case study from Mt. Carmel, Isreal. Forest Ecology and Management, 262, 1184-1188.

Peters, D.P., Gibbens, R.P. (2006). Plant communities in the Jornada Basin: the dynamic landscape. In: Havstad, K.M., Huenneke, L.F., Schlesinger, W.H. (Eds.), Structure and Function of a Chihuahuan Desert Ecosystem: the Jornada Basin Long-Term Ecological Research Site. New York, NY: Oxford University Press.

Phillips, A.R. (1974). Summary of avian resources of the Chihuahuan desert region (Transactions and Proceedings Series, 3, 617-620). Alpine, TX: National Parks Service.

Pianka, E. R. (1992). Fire Ecology. Disturbance, spatial heterogeneity, and biotic diversity: Fire succession in arid Australia. Research and Exploration, 8, 352-371.

Pronatura, The Nature Conservancy, The World Wildlife Fund. (2004). Ecoregional Conservation Assessment $f$ the Chihuahuan Desert (Second Edition). Colorado Springs: The Nature Conservancy.

Pyne, S.J. (1992). Fire in America, a cultural history of wildland and rural fire. New York, NY: Princeton University Press.

Pyne, S.J. (2001). Fire: A brief History. Washington Press: Seattle.

Ravi, S.; D’Odorico, P.; Herbert, B.; Zobeck, T.; Over, T. (2006). Enhancement of wind erosion by fire-induced water repellency. Water Resources Research, 42, 11422.

Ravi, S.; D’Odorico, P.; Wang, L.; White, C.; Okin, G.; Macko, S.; Collins, S. (2009). Post-Fire Resource Redistribution in Desert Grasslands: A Possible Negative Feedback on Land Degradation. Ecosystems, 12, 434-444.

Rhoda, R. \& Burton, T. (2010). Geo-Mexico: the geography and dynamics of modern Mexico. British Columbia, Canada: Sombrero books.

Richards, G.D., (1990). An elliptical growth mode of forest fire front and its numerical solution. Int. J. Numerical Methods in Engineering, 30, 1163-1179.

Richards, J. A. \& Jia, X. (1999). Remote sensing digital image analysis: An introduction (3rd ed.). Berlin: Springer.

Richards, N. \& Hay, I. (2007). Prescribed Burning. Encyclopedia of Environment and Society. Thousands Oaks, CA: SAGE Publications. 
Riaño, D; Chuvieco, E; Salas, J; Aguado, I. (2003). Assessment of Different Topographic Corrections in Landsat-TM Data for Mapping Vegetation Types. IEEE Transactions on Geoscience and Remote Sensing, 41(5), 2-14.

Rodríguez-Trejo, D.A. (2008). Fire Regimes, Fire Ecology, and Fire Management in Mexico. Ambio, 37(7), 548.

Rothermel, R.C. (1972). A mathematical model for predicting fire spread in wildland fuels. (Report No. RP INT-115). Ogden, UT: United States Forest Service.

Rothermel, R.C, R.A. Wilson, G.A. Morris, and S.S. Sackett. (1986). Modeling moisture content of fine dead wildland fuels input to the BEHAVE fire prediction system (Research Paper INT-359). Ogden, Utah: Intermountain Research Station United States Forest Service.

Rzedowski, J. (1991). El endemismo en la flora fanerógamica mexicana: una apreciación analítica preliminar. Acta Botánica Mexicana, 15, 47-64.

Rzedowski, J. (2006). Vegetación de México (1 ra Edición digital). Mexico, Mexico: Comisión para el Conocimiento y Uso de la Biodiversidad.

Sanderlin, J.C. \& Sunderson, J.M. (1975). A simulation for wildland fire managment planning support, FIREMAN, Volume II. Prototype models for FIREMAN: PART II (Contract No. 231-343, Spec. 222. 249). Campaign Fire Evaluation. United Kingdom: Cambridge University Press.

Sauer, C.O. (1950). Grassland climax, fire and man. Journal of Range Management, 3, $16-21$.

Schmidt, D.A.; Taylor, A.H.; Skinner, C.N. (2008). The influence of fuel treatment and landscape arrangement on simulated fire behavior, Southern Cascade range, California. Forest Ecology and Management, 255, 3170-3184.

Scott, J.H. \& Burgan, R.E. (2005). Standard Fire Behavior Fuel Models: A Comprehensive Set for Use with Rothermel's Surface Fire Spread Model (General Technical Report RMRS-GTR-153). Fort Collins, CO: Rocky Mountain Research Station, United States Forest Service.

Seager, R., M. F. Ting, I. M. Held, Y. Kushnir, J. Lu, G. Vecchiet al. (2007). Model projections of an imminent transition to a more arid climate in southwestern North America. Science, 316, 1181-1184.

Servicio Meteorológico Nacional (2010). Sequía. Retrieved from: $<$ http://smn.cna.gob.mx/index.php?option=com_content\&view=article\&id=236\&Itemi $\mathrm{d}=74>$ 
Simberloff, D. (1995). Why do introduced species appear to devastate islands more than mainland areas? Pacific Science, 49, 87-97.

Smith, J.A.; Lin, T.L.; Ranson, K.J. (1980). The Lambertian assumption and Landsat data. Photogram. Photogrammetric Engineering \& Remote Sensing, 46, 1183-1189.

Stephens, S.L. (1998). Evaluation of the effects of silviculture and fuel treatments on potential fire behaviour in the Sierra Nevada mixed- conifer forests. Forest Ecology and Management, 105, 21-35.

Stratton, D.R. (2004). Assessing the Effectiveness of Landscape Fuel Treatments on Fire Growth and Behavior. Forestry, 5(2004), 32-40.

Tachikawa, T.; Kaku, M.; Iwasaki, A.; Gesch, D.; Oimoen, M; Zhang, Z.; Danielson J.; Krieger, T.; Curtis, B.; Haase J.; Abrams, M.; Crippen, R.; Carabajal C. (2011). ASTER Global Digital Elevation Model Version 2 - Summary of Validation Results (ASTER GDEM V2 Validation Summary Report). Sioux Falls, SD: Aster GDEM Validation Team.

Thomas, P. A. (1991). Response of succulents to fire: a review. International Journal of Wildland Fire, 1(1), 11-22.

Tottrup, C. (2007). Forest and Land Cover Mapping in a Tropical Highland Region. Photogrammetric Engineering \& Remote Sensing, 73(9), 1057-1065.

Trabaud, L. (1987). Fire and survival traits of plants. In: Trabaud, L., ed. Role of fire in ecological systems. Hague, The Netherlands: SPB Academic Publishers.

Tymstra, C; Bryce, R.W.; Wotton, B.M.; Taylor, S.W.; Armitage, O.B. (2010). Development and Structure of Prometheus: The Canadian Wildland Fire Growth Simulation Model (Information Report NOR-X-417). Edmonton Alberta: Canadian Forest Service.

United Nations Convention to Combat Desertification. (1992). Report of the United Nations Conference on Environment and Development: Agenda 21, Chapter 12. (Technical report 151/26 Vol. II). Rio de Janiero, Brazil: United Nations

United States Fire Administration. (July 12, 2012). Trend in Overall Fire Deaths (20042008). Federal Emergency Management Agency. Retrieved from: $<$ http://www.usfa.fema.gov/statistics/estimates/trend_overall.shtm>

Van Wagner, C.E. (1977). Conditions for the start and spread of crown fire. Canadian Journal of Forest Research, 7, 23-24. 
Van Wagtendonk, J.W. (1996). Use of a deterministic fire growth model to test fuel treatments. Centers for Water and Wildland Resources, 2, 1155-1166.

Van Wagtendonk, J.W. (1997). Use of thermatic mapper imagery to map fuel models. Proceedings of the 13th Conference of Fire and Forest Meteorology. In press.

Van Wagtendonk, J.W. \& Root, R.R., (2003). The use of multitemporal Landsat normalized difference vegetation index (NDVI) data for mapping fuels models in Yosemite National Park, USA. International Journal of Remote Sensing, 24, 16391651.

Warren, A.; Holechek, J.; Cardenas, M. (1996). Honey mesquite influences on Chihauhuan desert vegetation. Journal of Range Management, 49, 46-52.

West, S. (2000). Northern Chihuahuan Desert Wildflowers. Helena, Montana: Falcon.

Williams, J.T. (2004). Managing fire-dependent ecosystems: We need a public lands policy debate. Fire Management Today, 64(2), 6-11.

Wooton, E.O., 1916. Carrying Capacity of Grazing Ranges in Southern Arizona (USDA Bulletin No. 367, Professional Paper). Washington, D.C.: Government Printing Office.

World Wildlife Fund. (October 24, 2011). Chihuahuan Desert: Protecting the Balance of a Desert. Where we Work. Retrieved from: <http://www.worldwildlife.org/what/ wherewework/chihuahuandesert/>

Worthington, R.D., \& Corral, R.D. (1987). Some Effects of Fire on Shrubs and Succulents in a Chihuahuan Desert Community in the Franklin Mountains, El Pas County, Texas. Contributed Papers of the Second Symposium on Resources of the Chihuahuan Desert Region. Chihuahuan Desert Research Institute.

Yang, J.; He, H.S.; Shifley, S.R. (2008) Spatial Controls of Occurrence and Spread of Wildfires in the Missouri Ozark Highlands. Ecological Applications, 18(5), 12121225 . 


\section{APPENDIX}

NFFL Fuel Model Photographs and SLM Photographs 

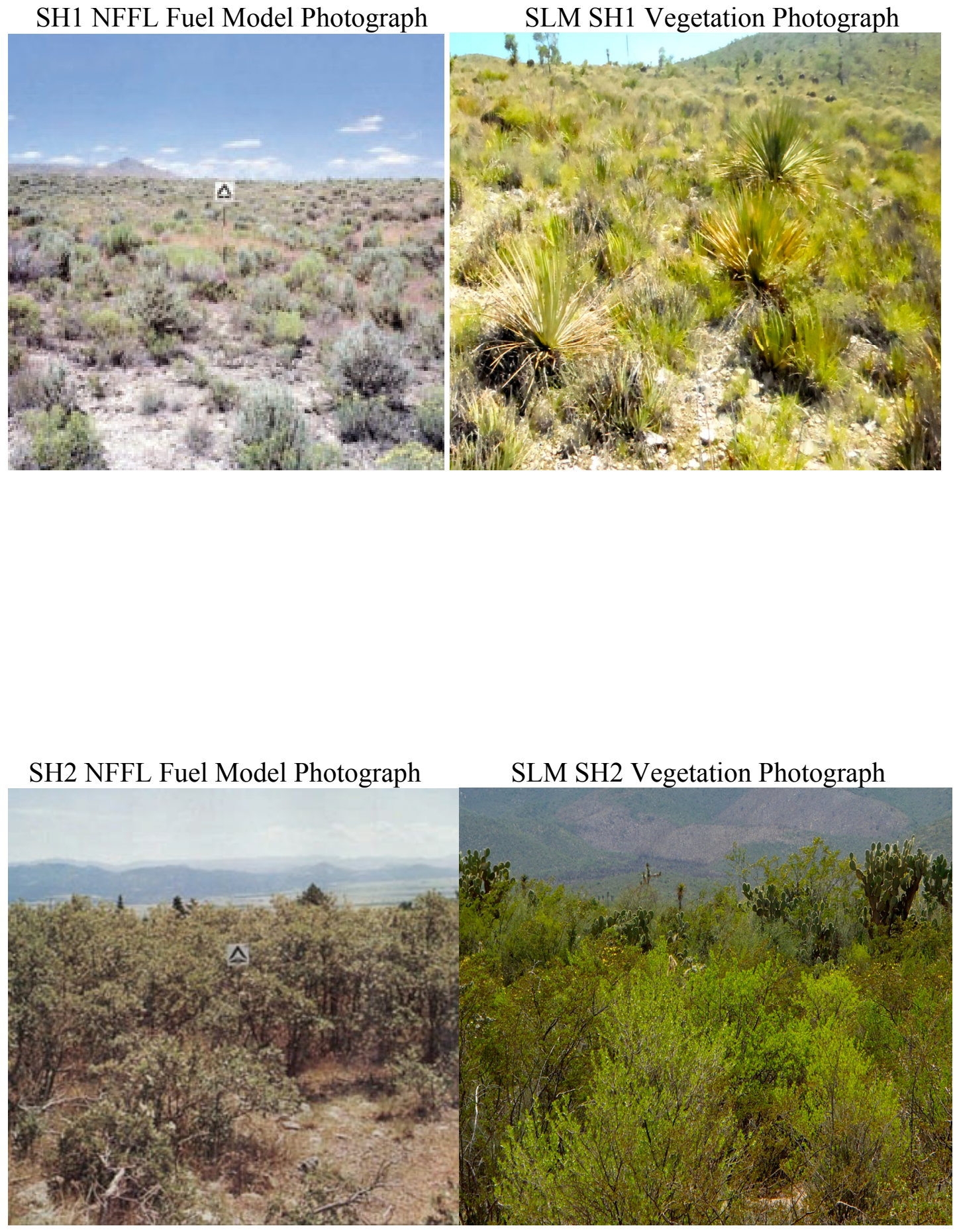


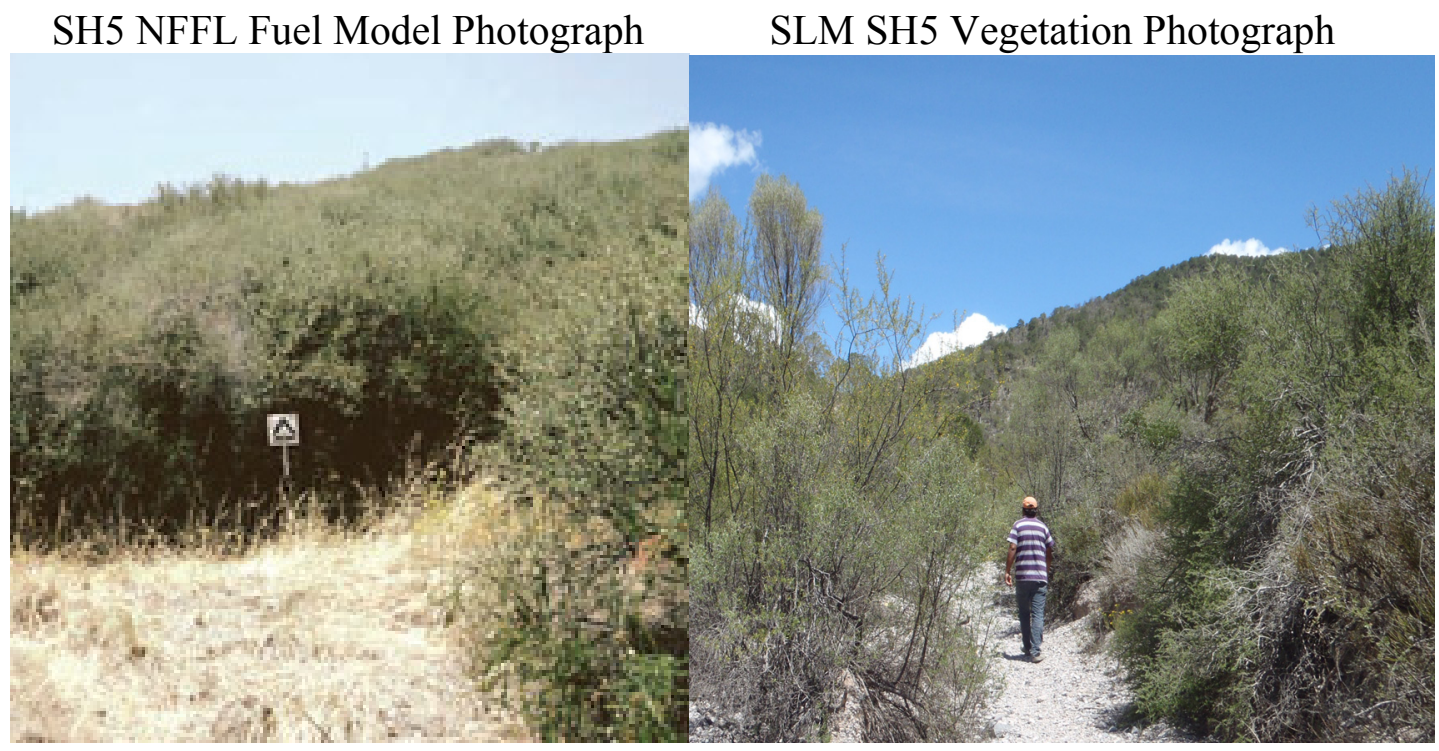

SH7 NFFL Fuel Model Photograph

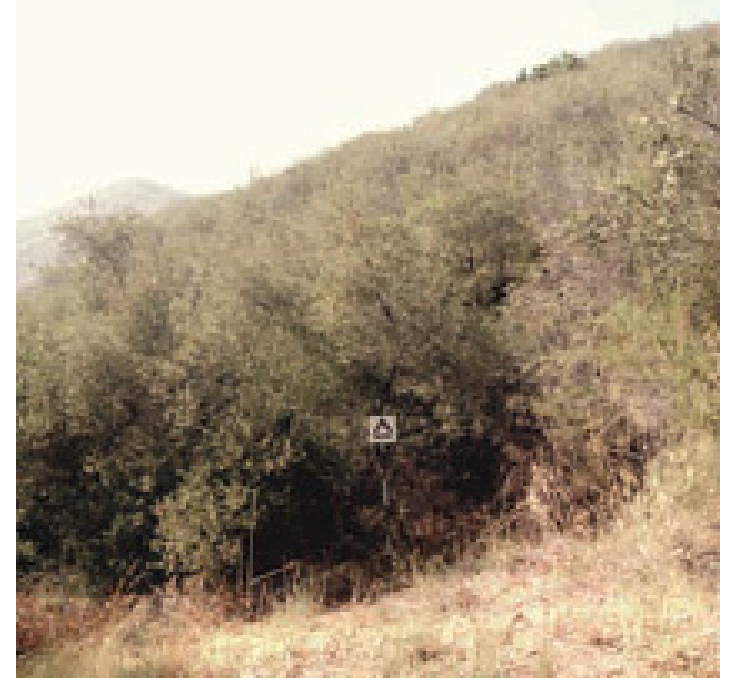

SLM SH7 Vegetation Photograph

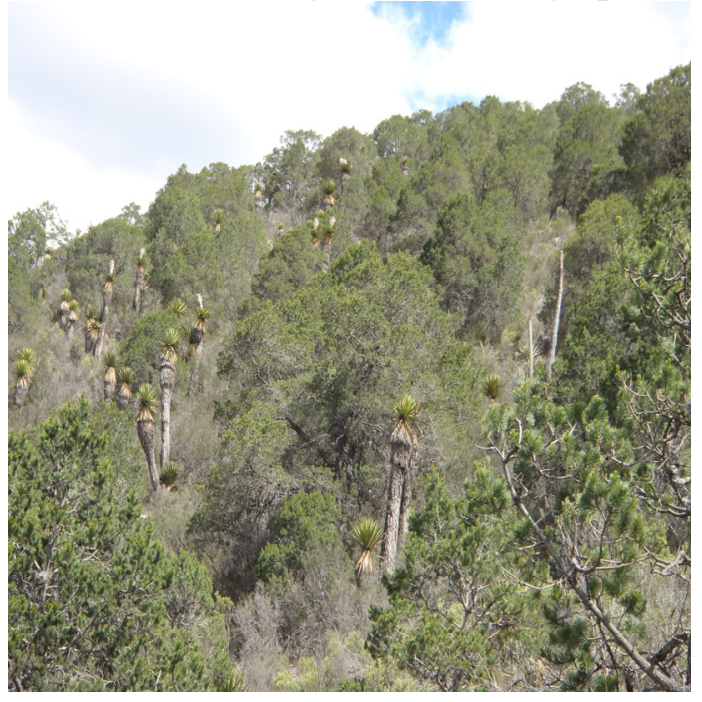

